\title{
Assessment of Selected Fission Products in the Savannah River Site Environment (U)
}

\author{
RECEIVED \\ MOV 031997 \\ OSTI
}

Westinghouse Savannah River Company

Savannah River Site

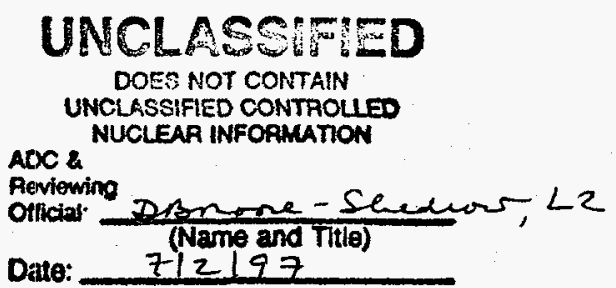

Aiken, SC 29808

Prepared for the U.S. Department of Energy under contract no. DE-AC09-89SR18035

ESTRIEUTION of Tis Do 


\section{DISCLAIMER}

This report was prepared as an account of work sponsored by an agency of the United States Government. Neither the United States Government nor any agency thereof, nor any of their employees, makes any warranty, express or implied, or assumes any legal liability or responsibility for the accuracy, completeness, or usefulness of any information, apparatus, product, or process disclosed, or represents that its use would not infringe privately owned rights. Reference herein to any specific commercial product, process, or service by trade name, trademark, manufacturer, or otherwise does not necessarily constitute or imply its endorsement, recommendation, or favoring by the United States Government or any agency thereof. The views and opinions of authors expressed herein do not necessarily state or reflect those of the United States Government or any agency thereof.

This report has been reproduced directly from the best available copy.

Available to DOE and DOE contractors from the Office of Scientific and Technical Information, P.O. Box 62, Oak Ridge, TN 37831; prices available from (615) 576-8401.

Available to the public from the National Technical Information Service, U.S. Department of Commerce; 5285 Port Royal Road, Springfield, VA 22161. 


\section{DISCLAMIER}

Portions of this document may be illegible in electronic irmage products. Images are produced from the best available original doceroment 


\section{Assessment of Selected Fission Products in the Savannah River Site Environment (U)}

W. H. Carlton

M. Denham

Approved by:

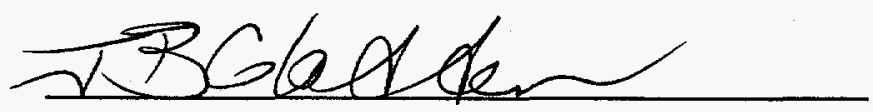

J. B. Gladden

Environmental Analysis Section

Prepared for the U.S. Department of Energy under contract no. DE-AC09-89SR18035 


\section{Contents}

\section{Executive Summary i}

Chapter 1. Introduction 1-1

Physical Characteristics 1-3

Radionuclide Monitoring and Reporting 1-3

References for Chapter 1 1-3

\section{Chapter 2. Origin and Disposition of Fission Products at SRS 2-1}

Origin of Fission Products at SRS 2-3

Irradiation in Production Reactor 2-3

Other Sources Attributable to SRS Operations 2-3

SRS Test Reactors 2-3

Spontaneous Fission 2-3

Neutron Activation Analysis 2-3

Materials Originating Offsite 2-4

Disposition of Fission Products at SRS 2-4

Fission Products in Fuel and Targets

Irradiated in Production Reactors 2-4

Fission Products in Certain Fuel Irradiated Offsite 2-5

Fission Products in Fuel and Targets Irradiated in Test Reactors 2-5

Fission Products from Spontaneous Fission 2-5

Neutron Activation Analysis Samples 2-5

Commercially Purchased Fission Products 2-5

Global-Fallout Fission Products 2-5

References for Chapter 2 2-5

\section{Chapter 3. Releases and Stored Inventories of Selected Fission Products'at SRS 3-1 \\ Reactor Facilities 3-3 \\ Facility Operations 3-3 \\ Pathways for Release 3-3 \\ Emission Control 3-4 \\ Release Monitoring 3-4 \\ History of Measured Releases 3-4}


C Reactor 3-5

K Reactor 3-5

L Reactor 3-5

P Reactor 3-5

R Reactor 3-6

Summary of Reactor Releases 3-6

Separations and Liquid Waste Facilities 3-6

Facility Operations 3-6

Pathways for Release 3-6

Emission Control 3-7

Release Monitoring 3-7

History of Measured Releases 3-7

F-Area Separations 3-7

Releases to Atmosphere 3-7

Ruthenium Release Incident 3-7

Releases to Streams 3-8

Releases to F-Area Seepage Basins 3-8

H-Area Separations 3-8

Releases to Atmosphere 3.8

Releases to Streams 3-8

Releases to H-Area Seepage Basins 3-9

Effluent Treatment Facility 3-9

Waste Tank Farms 3-9

Summary of Separations and Liquid Waste Facilities 3-9

Solid Waste Disposal Facility 3-9

Savannah River Technology Center 3-9

Other Facilities 3-9

References for Chapter 3 3-10

\section{Chapter 4. Selected Fission Product Concentrations and Transport Mechanisms 4-1}

Atmospheric Transport 4-3

Surface Water Transport 4-3

Surface Waters on the Savannah River Site 4-3

Lower Three Runs Creek 4-3

Upper Three Runs Creek 4-3

Steel Creek 4-3

Fourmile Branch 4-3

Pen Branch 4-3

Site Stream Summar y 4-4

Savannah River 4-4

Groundwater Concentrations and Transport 4-4

References for Chapter $4 \quad 4-4$ 
Chapter 5. Assessment of Dose/Risk from SRS Selected Fission Product Releases 5-1

Relationship of Dose to Risk and Health Effects 5-3 lonizing Radiation 5-3

Cancer Risk Estimates 5-3

Selected Fission Product Exposure and Dose to Man 5-3

Models of Fission Product Transport and Dose 5-3

Modeling Atmospheric Dispersion of Radioactive Releases 5-4

MAXIGASP 5-4

POPGASP 5-5

Modeling Doses from Liquid Releases 5-5

Validation of Transport Models Using Monitoring Data 5-9

Atmospheric Releases 5-9

Liquid Releases 5-9

Impact of SRS Selected Fission Product Releases

on the Offsite Population 5-9

Doses from Atmospheric Releases 5-9

Dose from ${ }^{95} \mathrm{Zr}, \mathrm{Nb} \quad 5-9$
Dose from ${ }^{95} \mathrm{Nb} \quad 5-9$
Dose from ${ }^{103} \mathrm{Ru} \quad 5-9$
Dose from ${ }^{106} \mathrm{Ru} \quad 5-9$
Dose from ${ }^{141} \mathrm{Ce} 5-9$
Dose from ${ }^{144} \mathrm{Ce} \quad 5-9$

Individual Doses from Liquid Releases 5-10

Dose from ${ }^{95} \mathrm{Zr}, \mathrm{Nb}$. 5-10

Dose from ${ }^{106} \mathrm{Ru}$ 5-10

Dose from ${ }^{144} \mathrm{Ce} 5-10$

Sum of All Liquid Release Doses 5-10

Collective Doses from Liquid Releases 5-11

Comparisons of Selected Fission Product Doses Near SRS with Applicable Regulations 5-11

Atmospheric Releases 5-11

Liquid Releases 5-11

Summary of Dosimetric Impacts 5-11

References for Chapter 5 5-12

\section{Additional Reading 5-22}

\section{List of Figures}

Figure 2.1. Areas Within SRS that May Be Sources of Selected Fission Product Releases 2-2

Figure 3.1. Proximity of SRS Facilities to Site Streams 3-2

Figure 3.2. Releases to Streams, C Area 3-19

Figure 3.3. Releases to Basins, C Area 3-19

Figure 3.4. Releases to Streams, K Area 3-20

Figure 3.5. Releases to Basins, K Area 3-20

Figure 3.6. Releases to Streams, L Area 3-21 
Figure 3.7. Releases to Basins, L Area 3-21

Figure 3.8. Releases to Streams, P Area 3-22

Figure 3.9. Releases to Basins, P Area 3-22

Figure 3.10. Releases to Streams, R Area 3-23

Figure 3.11. Releases to Basins, $R$ Area 3-23

Figure 3.12. Releases to Atmosphere of $\mathrm{Zr}-\mathrm{Nb}, \mathrm{F}$ Area 3-24

Figure 3.13. Releases to Atmosphere of Ru, F Area 3-24

Figure 3.14. Releases to Atmosphere of Ce, F Area 3-25

Figure 3.15. Releases to Basins of Zr-Nb, F Area 3-25

Figure 3.16. Releases to Basins of Ru, F Area 3-26

Figure 3.17. Releases to Basins of Ce, F Area 3-26

Figure 3.18. Releases to Atmosphere of $\mathrm{Zr}-\mathrm{Nb}, \mathrm{H}$ Area 3-27

Figure 3.19. Releases to Atmosphere of Ru, H Area 3-27

Figure 3.20. Releases to Atmosphere of $\mathrm{Ce}, \mathrm{H}$ Area 3-28

Figure 3.21. Releases to Basins of $\mathrm{Zr}-\mathrm{Nb}, \mathrm{H}$ Area 3-28

Figure 3.22. Releases to Basins of Ru, H Area 3-29

Figure 3.23. Releases to Basins of $\mathrm{Ce}, \mathrm{H}$ Area 3-29

Figure 5.1. Simplified Pathways Between Radioactive Materials Released to the Atmosphere and Man 5-5

Figure 5.2. Simplified Pathways Between Radioactive Materials Released to Groundwater or Surface Waters and Man 5-8

\section{List of Tables}

Table 1-1. Physical Characteristics of Selected Fission Products (ICRP 1983) 1-3

Table 3-1. C-Area Releases 3-11

Table 3-2. K-Area Releases 3-12

Table 3-3. L-Area Releases 3-13

Table 3-4. P-Area Releases 3-14

Table 3-5. R-Area Releases 3-15

Table 3-6. F-Area Releases 3-16

Table 3-7. H-Area Releases 3-18

Table 3-8. D-Area Releases 3-20

Table 4-1. Releases to Streams by Area 4-3

Table 5-1. Site-Specific Parameters for Atmospheric Releases 5-6

Table 5-2. Site-Specific Parameters for Liquid Releases 5-7

Table 5-3. Additional Site-Specific Parameters for Liquid Releases 5-7

Table 5-4. Atmospheric $95 \mathrm{Zr}$, Nb Releases and Dose 5-13

Table 5-5. Atmospheric $95 \mathrm{Nb}$ Releases and Dose 5-14

Table 5-6. Atmospheric ${ }^{103}$ Ru Releases and Dose 5-15

Table 5-7. Atmospheric ${ }^{106}$ Ru Releases and Dose 5-16 
Assessment of Selected Fission Products

in the Savannah River Site Environment (U)

Table 5-8. Atmospheric ${ }^{141} \mathrm{Ce}$ Releases and Dose 5-17

Table 5-9. Atmospheric ${ }^{144} \mathrm{Ce}$ Releases and Dose 5-18

Table 5-10. Stream Releases of $95 \mathrm{Zr}, \mathrm{Nb}$ and Dose 5-19

Table 5-11. Stream Releases of ${ }^{106} \mathrm{Ru}$ and Dose 5-20

Table 5-12. Stream Releases of ${ }^{144} \mathrm{Ce}$ and Dose 5-21

8 


\section{Executive Summary}

A series of documents has been published that assesses the impact of various radionuclides released to the environment by Savannah River Site (SRS) operations. The quantity released, the disposition of the radionuclides in the environment, and the dose to offsite individuals has been presented for carbon, cesium, iodine, plutonium, strontium, technetium, tritium, uranium, the noble gases, and activation products. An assessment of the impact of nonradioactive mercury also has been published.

This document assesses the impact of selected radioactive fission products released from SRS facilities since the Site's first reactor started operations in 1953. The radionuclides reported here are those fission products, not previously described, whose release resulted in the highest dose to people living near SRS: and, these radionuclides are ${ }^{95} \mathrm{Zr},{ }^{95} \mathrm{Nb},{ }^{103} \mathrm{Ru},{ }^{106} \mathrm{Ru}$, and ${ }^{141} \mathrm{Ce}$, and ${ }^{144} \mathrm{Ce}$.

Release pathways, emission control features, and annual releases to the aqueous and atmospheric environments are discussed. The releases were mostly the result of normal operations of the reactors and separations facilities. Releases declined through the years as better controls were established, and production was reduced.

The overall radiological impact of SRS selected fission product atmospheric releases between 1954 and 1994 on the offsite maximally exposed individual can be characterized by a total dose of $4.5 \mathrm{mrem}$. During the same period, such an individual received a total dose of 14,400 mrem from non-SRS sources of ionizing radiation present in the environment. Selected fission product aqueous releases at SRS between 1954 and 1994 resulted in a total dose of 16 mrem.

The impact of SRS selected fission product releases on offsite populations also has been evaluated. The total collective dose was estimated at 210 person-rem, distributed among 620,100 individuals. Using international dose factors, less than one cancer death is predicted from SRS releases while almost 100,000 fatal cancers will occur in this population from all other causes.

Selected fission products released from SRS present a negligible risk to the offsite environment and the population it supports. 


\section{Chapter 1. Introduction}

Most of the radioactivity produced by the operation of a nuclear reactor results from the fission process, during which the nucleus of a fissionable atom (such as ${ }^{235} U$ ) splits into two or more nuclei, which typically are radioactive. The Radionuclide Assessment Program (RAP) has reported on fission products cesium, strontiutm, iodine, and technetium. Many other radionuclides are produced by the fission process. Releases of several additional fission products that result in dose to the offsite population are discussed in this publication. They are ${ }^{95} \mathrm{Zr},{ }^{95} \mathrm{Nb},{ }^{103} \mathrm{Ru},{ }^{106} \mathrm{Ru},{ }^{141} \mathrm{Ce}$, and ${ }^{144} \mathrm{Ce}$. This document will discuis the production, release, migration, and dose to humans for each of these selected fission products. 
This page intentionally left blank. 


\section{Physical Characteristics}

Zirconium-95 decays, with a half-life of 64 days, to ${ }^{95} \mathrm{Nb}$ through the emission of a beta particle. Niobium-95 in turn decays, with a half-life of 35 days, to stable ${ }^{95}$ Mo through the emission of a low-energy beta particle. Several energetic gammas also are emitted.

Ruthenium-103 decays, with a half-life of 39 days, to ${ }^{103} \mathrm{Rh}$ through the emission of a beta particle. A 0.497 $\mathrm{MeV}$ gamma is emitted.

Ruthenium-106 decays, with a half-life of 368 days, to ${ }^{106} \mathrm{Rh}$ through the emission of a beta particle. Rhodium106 in turn decays, with a half-life of 30 seconds, to stable ${ }_{106} \mathrm{Pd}$ through the emission of a energetic beta particle. Several gammas are emitted.

Cerium-141 decays, with a half-life of 33 days, to stable ${ }^{141}$ Pr through the emission of a beta particle.

Cerium-144 decays, with a half-life of 284 days, to ${ }^{144} \mathrm{Pr}$ through the emission of a beta particle. Praseodymium144 in turn decays, with a half-life of 17 minutes, to ${ }^{144} \mathrm{Nd}$, which is so slightly radioactive that it contributes no dose to humans.

The physical characteristics are summarized in Table 1-1.

\section{Radionuclide Monitoring and Reporting}

Prior to 1971 , cerium activity was not reported by isotope but as ${ }^{141,144} \mathrm{Ce}$. Beginning in 1971, F-Area and H-Area releases were reported as ${ }^{141} \mathrm{Ce}$ and ${ }^{144} \mathrm{Ce}$, while all other areas continued to report ${ }^{141.144} \mathrm{Ce}$ activity. In this report, ${ }^{141},{ }^{144} \mathrm{Ce}$ will be listed as ${ }^{144} \mathrm{Ce}$, and dose will be calculated for ${ }^{144} \mathrm{Ce}$ because the dose from inhalation and ingestion of ${ }^{144} \mathrm{Ce}$ is greater than the dose from ${ }^{141} \mathrm{Ce}$.

Most releases of ${ }^{95} \mathrm{Zr}$ and ${ }^{95} \mathrm{Nb}$ were reported as ${ }^{95} \mathrm{Zr}, \mathrm{Nb}$. In this document, doses from atmospheric releases are calculated as if the entire release were ${ }^{95} \mathrm{Zr}$ because the dose from ${ }^{95} \mathrm{Zr}$ is higher than from ${ }^{95} \mathrm{Nb}$. On the other hand, doses from the aqueous releases are calculated as if the entire release were ${ }^{95} \mathrm{Nb}$ or ${ }^{95} \mathrm{Zr}$, whichever gives the higher dose. This unusual situation occurs because of the greater (approximately four orders of magnitude) bioaccumulation of $\mathrm{Nb}$ in fish.

\section{References}

International Commission on Radiological Protection (ICRP), 1983, Radionuclide Transformations, Oxford: Pergamon Press; ICRP Publication 38.x

Table 1-1. Physical Characteristics of Selected Fission Products (ICRP 1983)

\begin{tabular}{lllll}
\hline Radionuclide & Half-Life & Decays to & $\begin{array}{l}\text { Max. Beta } \\
\text { Energy (MeV) }\end{array}$ & $\begin{array}{l}\text { Gamma } \\
\text { Energy } \\
(\mathrm{MeV})\end{array}$ \\
\hline $\mathrm{Zr}-95$ & 64 days & Nb-95* & 0.89 & 0.750 \\
$\mathrm{Nb}-95$ & 35 days & Mo-95 & 0.16 & 0.724 \\
$\mathrm{Ru}-103$ & 39 days & Rh-103 & 0.70 & 0.766 \\
$\mathrm{Ru}-106$ & 368 days & Rh-106* & 0.39 & 0.497 \\
$\mathrm{Ce}-141$ & 33 days & Pr-141 & 0.58 & none \\
$\mathrm{Ce}-144$ & 284 days & Pr-144* & 0.31 & 0.145 \\
& & & & 0.134 \\
\end{tabular}

* This nuclide is also radioactive. 


\section{Chapter 2. Origin and Disposition of Fission Products at SRS}

This chapter presents an overview of the origin, uses, and disposition of selected fission products $\left({ }^{95} \mathrm{Zr},{ }^{95} \mathrm{Nb},{ }^{103} \mathrm{~K} u\right.$, ${ }^{106} \mathrm{Ru},{ }^{141} \mathrm{Ce}$, and ${ }^{144} \mathrm{Ce}$ ) at SRS under normal operating conditions. The locations of SRS facilities that had the potential to release fission products are shown in Figure 2.J. The greatest releases occurred during the early years of Site operations and originated in the chemical separations facilities and the reactor facilities, which are located near the center of the 800-square-km site. The history of actual releases from specific SRS facilities is presented in Chapter 3. 


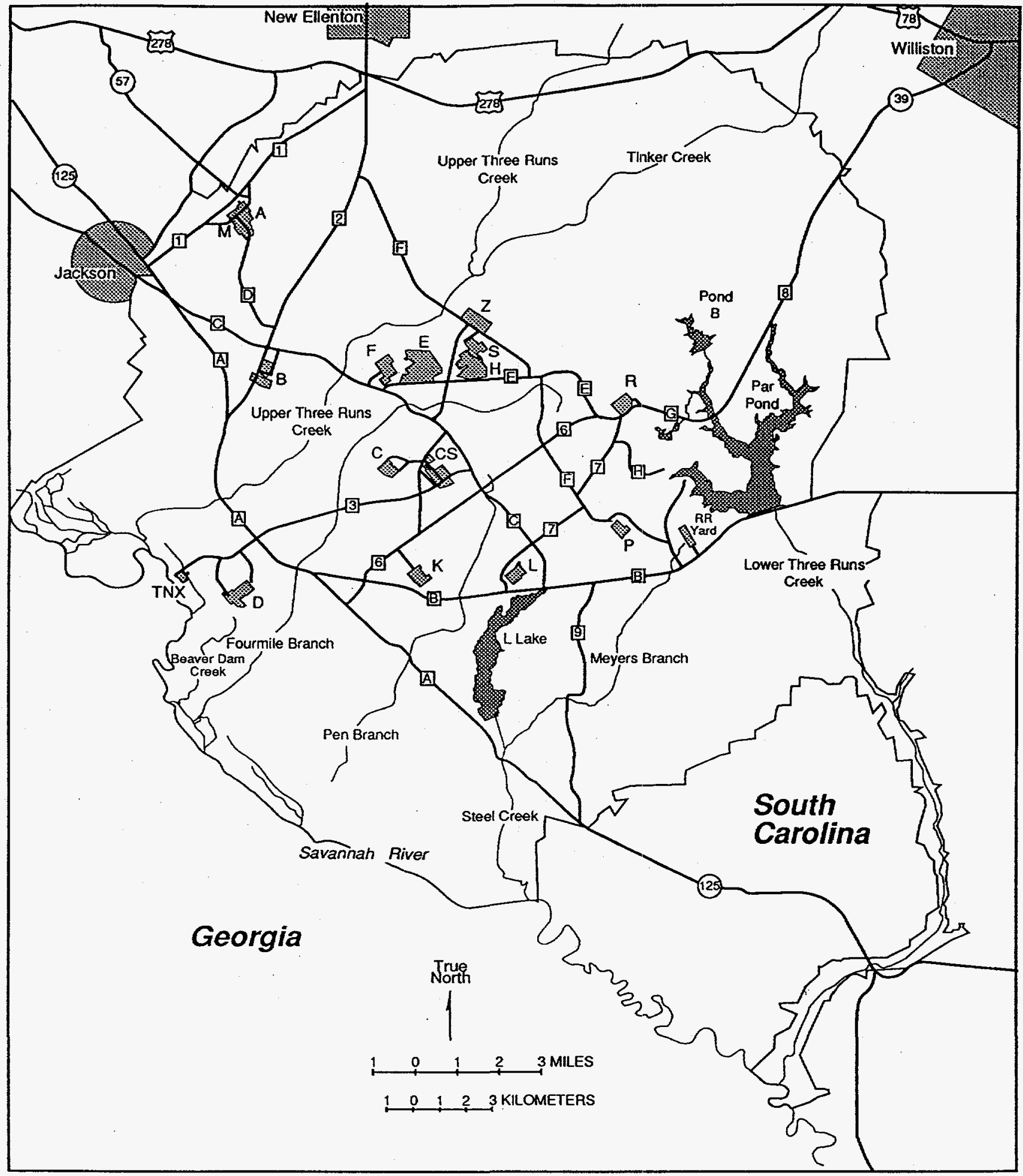

$93 A 030.03$

Figure 2.1. Areas within SRS that May Be Sources of Selected Fission Product Releases 


\section{Origin of Fission Products at SRS}

Fission products at SRS originated predominantly in the fuel and targets that were irradiated in the reactor cores of the Site's five production reactors. Other Site operations and offsite sources contributed slightly to the inventory of fission products at SRS.

\section{Irradiation in Production Reactors}

The role of the production reactors was to produce special nuclear materials, principally tritium and plutonium, for national defense purposes. Additional radionuclides, such as ${ }^{238} \mathrm{Pu}$, which is a power source for certain deep-space missions, were produced occasionally for other government purposes.

The reactors became operational in 1953-1955, but they did not operate continuously. The reactors alternated between periods of production and periods for maintenance or fuel and target replacement. As of 1996, four reactors were inactive, and one was on standby. The history of individual reactor operations is discussed in Chapter 3.

The principal mechanism to produce fission products in the reactors is neutron-induced fission. When a reactor was operating, neutron-induced fission reactions occurred in the ${ }^{235} \mathrm{U}$ fuel of the reactor core. Fission reactions formed a variety of fission products.

In addition to fission products, each neutron-induced fission reaction in the fuel produced several neutrons, some of which induced additional fission reactions and maintained a chain reaction. Some of the remaining neutrons interacted with target materials in the reactor. (Fuel and targets were encapsulated separately and referred to as elements.) One such interaction, neutron capture in a ${ }^{238} \mathrm{U}$ target, resulted in a special nuclear material, ${ }^{239} \mathrm{Pu}$.

In certain target materials, such as ${ }^{238} \mathrm{U}$, neutron-induced fission is a competing reaction. In the case of ${ }^{238} \mathrm{U}$ targets, fission also occurs in the minor constiturents, such as ${ }^{235} \mathrm{U}$ and ${ }^{239} \mathrm{Pu}$.

\section{Other Sources Attributable to SRS Opera- tions}

Small quantities of fission products were produced at SRS by test reactors, spontaneous fission, and neutron activation analysis. The activity levels from these sources were insignificant when compared to the activity levels in irradiated nuclear fuel and targets. However, these sources are discussed in the following subsections for a complete overview of potential fission product releases.

\section{SRS Test: Reactors}

Several small nuclear reactors were in use at two SRS locations from the 1950s through the 1970s. The Heavy Water Components Test Reactor (HWCTR), located in B Area, was used in the early 1960 s to test prototype fuels for a proposed heavy water-moderated power reactor. The other test reactors, located in M Area, were used from the mid 1950s to the late 1970s. The Process Development Pile and the Lattice Test Reactor were used as zero-power mock-up facilities to test components for the production reactors. The Subcritical Experimental Pile also was used to test component designs. The Standard Pile provided neutrons for experiments such as neutron radiography and neutron activation.

\section{Spontaneous Fission}

Spontaneous fission is a radioactive decay mode that occurs in heavy elements such as uranium and produces neutrons and fission products. Spontaneous fission is one of the means to produce fission products in nature. The occurrence of spontaneous fission ranges from rare to frequent. An example of a radionuclide in which spontaneous fission rarely occurs is ${ }^{238} \mathrm{U}$.

Californium-252, produced in SRS reactors by the inradiation of ${ }^{244} \mathrm{Cm}$ targets, is a valuable neutron source because it frequently undergoes spontaneous fission. From the mid 1960s until 1987, the Savannah River Technology Center (SRTC) fabricated industrial and medical ${ }^{252} \mathrm{Cf}$ sources for offsite use. Some of the sources were retained at SRS for neutron calibrations in the ${ }^{252} \mathrm{Cf}$ fabrication facility and for two neutron aclivation facilities. One ${ }^{252} \mathrm{Cf}$ neutron activation facility was operated in M Area in the 1970s; the other has been operational at SRTC since the mid 1970s. Fission products were produced during the spontaneous fission of ${ }^{252} \mathrm{C}$. .

Isotopes of uranium, thorium, plutonium, and curium also spontaneously fission. One or more of the materials discussed in this subsection were used in M Area, the reactor areas, the chemical separations areas, the Naval Fuels Facility, TNX Semiworks, and SRTC.

\section{Neutron Activation Analysis}

Neutron activation analysis measures elemental compositions in materials. The ${ }^{252} \mathrm{Cf}$ neutron activation facilities and the $\mathrm{C}$ and $\mathrm{K}$ production reactors were used for the analysis of low levels of ${ }^{129} \mathrm{I}$ and uranium. For exam- 
ple, from the late 1970 s to mid 1980 s, environmental samples were activated in $C$ Reactor to determine uranium content. Traces of fission products were produced in the irradiated samples.

\section{Materials Originating Offsite}

Certain fuels, irradiated at offsite non-commercial facilities, were shipped to SRS for reprocessing. While awaiting reprocessing, the fuels were stored in the Receiving Basin for Offsite Fuel (RBOF), located in H Area.

Additional fission products were purchased from commercial vendors. The radionuclides were used at SRS and SREL for experimental purposes, such as chemical yield determination, and for instrument calibration. The amounts are insignificant when compared to those produced in fuel and targets in SRS production reactors or produced in offsite fuel but stored in RBOF.

\section{Disposition of Fission Products at SRS}

The principal means for disposing of fission products are containment and time, which allow radioactive decay to occur. Table 1-1 shows that the selected fission products discussed in this document decayed with half-lives of one year or less.

\section{Fission Products in Fuel and Targets Irradiated in Production Reactors}

Under ideal operating conditions, fission products were contained within the cladding of fuel and target elements during both irradiation and cooling, the interval between the end of irradiation and the beginning of chemical separations. Irradiated materials are stored underwater in reactor basins for most of this time. Beginning in the 1970s, the cooling time for most irradiated materials was increased to at least 200 days to control radioiodine emissions.

Under normal operating conditions, it was possible for fission products to escape from irradiated fuel and target elements to the reactor moderator or to the water in the cooling basins through small defects in the cladding. Air and water at reactors were monitored for such releases. Actual releases are described in greater detail in Chapter 3.

Occasionally, the small defects developed into holes or splits in the cladding. This was called failure of the element. When a failure occurred, the reactor was shut down, and the failed element was transferred into a container called a "harp", which was stored underwater in the reactor basin and vented to the reactor stack. Failures occurred more frequently in the early years of operation.

A failed element had the potential to contaminate the moderator with fission products-SRS reactors used heavy water as a moderator. When the moderator and miscellaneous waters were purified in the treatment systems at the reactors or the Heavy Water Rework Facility in D Area, there was a potential for minute quantities of fission products to be released. These quantities generally were not measurable by routine methods.

Water in the reactor cooling basins also had the potential to become contaminated with fission products. Beginning in the $1960 \mathrm{~s}$, basin water was decontaminated routinely by passing the water through ion exchange resins to remove most of the radionuclides. Spent resins were reworked in the Resin Regeneration Facility in H Area or buried in the Burial Grounds--renamed the Solid Waste Disposal Facility (SWDF) in 1990.

After cooling, fuel and targets were treated in the chemical separations areas. During the chemical separations process, targets were treated by the Purex process in F Area to recover ${ }^{239} \mathrm{Pu},{ }^{237} \mathrm{~Np}$, and ${ }^{238} \mathrm{U}$ from irradiated ${ }^{238} \mathrm{U}$. The Purex process extracted plutonium and uranium into an organic solvent for separation and purification from waste products. Fuel was treated by the H-Modified Purex (HM) process in $\mathrm{H}$ Area to recover ${ }^{235} \mathrm{U}$ and ${ }^{237} \mathrm{~Np}$ from irradiated ${ }^{235} \mathrm{U}$; until 1959 the Purex process was used in $\mathrm{H}$ Area. The principal difference is that the HM process uses mercuric nitrate as a catalyst to enhance dissolution of the irradiated fuel. Also in $\mathrm{H}$ Area, ${ }^{238} \mathrm{Pu}$ occasionally was recovered from ${ }^{237} \mathrm{~Np}$ targets by the Frames process.

During chemical separations, small quantities of fission products were volatilized when aqueous wastes were evaporated and subsequently discharged to seepage basins. Small quantities of fission products entered the process cooling water streams in both F Area and $\mathrm{H}$ Area as a result of heating and cooling coil leaks. While the bulk of this activity was collected in retention basins and subsequently transferred to the seepage basins, some leakage did occur into Fourmile Branch (also known as Four Mile Creek). Additional small quantities seeped through small cracks that developed in some of the high-activity waste tanks and subsequently spilled into the soil underneath the tanks.

Aqueous wastes from the chemical separations processes were evaporated and sent to underground storage tanks for radioactive waste. The evaporator condensate was sent to 
the separations area seepage basins until November 1988 , when use of the seepage basins was terminated. Miscellaneous aqueous wastes were treated periodically by the evaporation process.

Beginning in November 1988, condensate was sent to the Effluent Treatment Facility (ETF), where it was treated to remove radionuclides (except tritium) and chemicals before discharge to Upper Three Runs Creek.

High-level liquid wastes generated in SRTC operations were stored in temporary waste tanks, where short-lived radionuclides decayed to insignificant levels. Periodically, the contents of the waste tanks were shipped to F Area and processed through the waste system. Solid wastes generated in the SRTC handling operations were buried in the SWDF.

Most of the atmospheric and aqueous effluents in the chemical separations areas and SRTC have been monitored for possible fission product releases. Monitoring techniques and measured releases from the chemical separations areas are described in Chapter 3.

The distributions to the atmosphere, seepage basins, and site streams had a direct impact on the environment. Waterborne fission products were measured in site streams. Fission product activity released through stacks was insignificant enough that offsite transport through the atmosphere has not been detected.

\section{Fission Products in Certain Fuel Irradiated Offsite}

Irradiated fuels received from certain offsite facilities were stored underwater in RBOF until chemical separation. The fuel then entered the regular process stream in H Area. The disposition of fission products became the same as described for fuel irradiated in SRS production reactors.

\section{Fission Products in Fuel and Targets Irradiated in Test Reactors}

Fuels and targets from the various test reactors were sent primarily to RBOF for cooling before chemical separation. Some were sent to SRTC for research or to reactor materials fabrication facilities that only received fuel or targets that were not irradiated; this material was blended into the standard fabrication process for targets and fuel to be used in the production reactors. Because only minute quantities of naturally produced fission products occurred in the fabricated materials, no monitoring for fission products was conducted at fabrication facilities.

\section{Fission Products from Spontaneous Fission}

Fission products produced by spontaneous fission in thorium, uranium, plutonium, and curium are retained by these elements as long as they remain in solid form. Fission products produced by spontaneous fission in ${ }^{252} \mathrm{Cf}$ are retained as long as the californium remains encapsulated.

\section{Neutron Activation Analysis Samples}

Environmental samples were analyzed by high-sensitivity neutron activation to detect trace levels of uranium and ${ }^{129} \mathrm{I}$. Typically, the uranium analysis was nondestruclive; therefore, any fission products produced from fission of uranium were not released. The fission product content was minute, and the samples were disposed of at the SWDF as solid radioactive waste.

The analysis for ${ }^{129}$ I typically involved chemical purification of iodine at SRTC after irradiation. In the purification steps, traces of fission products could have been released to the SRTC exhaust system. None of these trace releases were significant enough to be detected during routine monitoring of the SRTC stacks.

Traces of fission products were retained in various liquids, which were used in the purification steps and then stored as waste in the SRTC temporary waste tanks. These wastes subsequently were concentrated by evaporation and added to the high-level wastes awaiting processing in the DWPF.

\section{Commercially Purchased Fission Products}

Fission products were purchased from commercial vendors for standardization of counting room instruments in several SRS laboratory facilities. The quantities were extremely small and were disposed of as solid radioactive waste when radioactive decay ended their usefulness.

\section{Global-Fallout Fission Products}

Most global fallout occurred because of atmospheric nuclear weapons tests and the Chernobyl accident. Global fallout often was detectable in the vicinity of SRS during the 1950 s, early 1960 s, and 1986 , but fallout was not uniformly distributed throughout the terrestrial environment in the vicinity of SRS. Such unpredictability in the terrestrial distribution was well known in the early $1960 \mathrm{~s}$ (Bruner 1963).

\section{References for Chapter 2}

Bruner, H. D., 1963, "Symposium on the Biology of Radioiodine: Statement of the Problem", Health Physics, 9:1083. 


\section{Chapter 3. Releases and Stored Inventories of Selected Fission Products at SRS}

Routine operations at SRS facilities have released fission products to the regional environment surrounding SRS. The most significant releases occurred during the 1960s and early 1970s, when fission products were released to the atmosphere, site streams, and seepage basins. Almost all atmospheric releases occurred in F Area and $H$ Area, located near the center of the 800-square-km site. Almost all stream releases occurred in the reactor areas $(C, K, L, P$, and $R$ ). The proximity of these areas to major streams within the SRS boundary is shown in Figure 3.1, which also shows the location of other facilities having the potential to release fission products.

This chapter discusses selected fission products at SRS facilities in terms of possible release pathways, emission control features, and annual releases to the atmospheric and aqueous environments. 


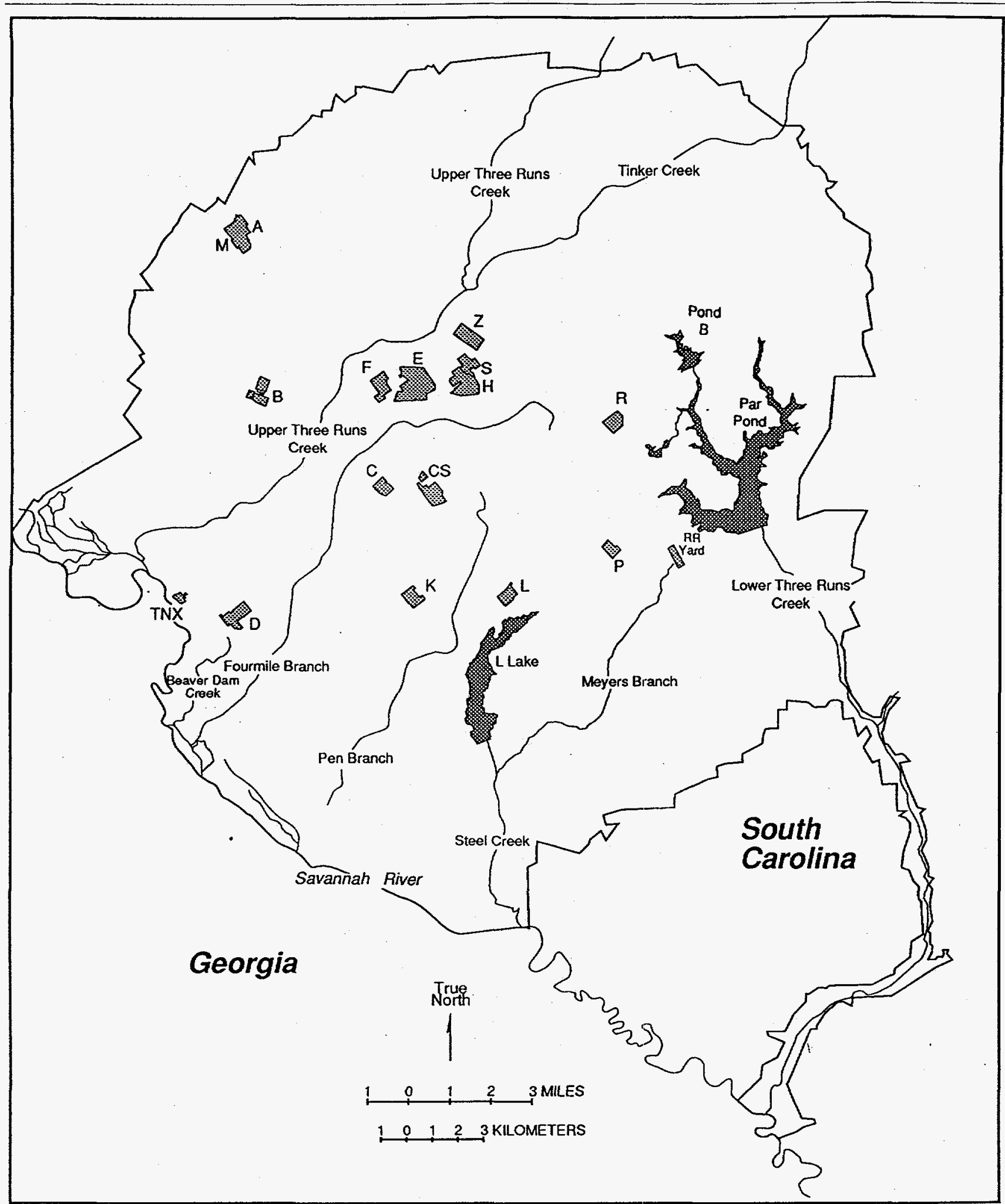

M93A030.04

Figure 3.1. Proximity of SRS Facilities to Site Streams 


\section{Reactor Facilities}

The five production reactors at SRS-identified by the letter designations $\mathrm{C}, \mathrm{K}, \mathrm{L}, \mathrm{P}$, and $\mathrm{R}$-were designed to irradiate various targets to produce special nuclear materials (principally tritium and plutonium) for national defense purposes. Specific radionuclides for other government purposes also were produced, including ${ }^{238} \mathrm{Pu}$, a power source for certain deep-space missions.

\section{Facility Operations}

When a nuclear reactor was operating, nuclear fission reactions occurred in the reactor core. The principal components of the core were the fuel, targets, control rods, and moderator. Control rods were neutronabsorbing materials positioned in the core to control the power level of a reactor.

The moderator in SRS reactors was heavy water, which was circulated around the fuel and target elements in the reactor core. The moderator decreased the kinetic energy (slowed the speed) of neutrons emitted in the fission process. Slow neutrons are more likely than fast neutrons to interact with fuel and target materials.

The moderator also functioned as the primary coolant to remove heat from fuel and target elements. Heat then was transferred from the moderator to the secondary coolant by heat exchangers. Reactors at SRS used either river or pond water as the secondary coolant in the heat exchangers.

In reactors that used water from the Savannah River as the secondary coolant, the river water was passed through the shell side of the heat exchanger and discharged to a site stream that flowed back to the Savannah River. When $L$ Reactor was upgraded and restarted in the 1980s, a cooling lake (L Lake) was constructed to mitigate the thermal impact on Steel Creek. River water was pumped through the L-Area heat exchangers and discharged into L Lake without recirculation. L Lake overflowed into Steel Creek. Reactors that used pond water as the secondary coolant discharged the water from the heat exchanger to a canal that flowed to a series of cooling ponds. Cooled pond water was recirculated through the heat exchanger.

Under normal operating conditions, fuel and target elements were irradiated for a specified time, removed from the reactor core, and stored underwater in the Vertical Tube Storage (VTS) basin of the reactor building. Storage in the VTS basin for the cooling period allowed short-lived radionuclides to decay to low levels before reprocessing of the fuel and targets began. After cooling, the elements were moved to the disassembly basin and prepared for transfer to the chemical separations areas.

\section{Pathways for Release}

During normal reactor operations, traces of fission products escaped from irradiated fuel or target elements if a defect developed in the cladding. The defect typically was a micro-scale crack. If a defect developed while the element was in the reactor core, fission products escaped from the irradiated material to the moderator by leaching from the exposed irradiated material.

Some of the exposed uranium and plutonium from failed elements became dispersed in the moderator. After the failed elements were removed and the reactor was restarted, the dispersed uranium and plutonium continued to circulate with the moderator. Neutrons generated during subsequent reactor operation caused fission in any circulating uranium and plutonium, thereby producing small quantities of fission products directly in the moderator. Most of these impurities were removed from the moderator by an online ion-exchange purification process.

Once fission products were in the moderator, they could circulate with the moderator and adsorb onto fuel and target surfaces. Low operating temperatures of the reactors (below the boiling temperature of heavy water) minimized the volatilization of fission products into the blanket gas. When a leak developed in a heat exchanger tube, some fission products were released along with primary coolant into the secondary coolant-and subsequently to the environment. Any fission products released by this pathway were not quantified; however, the secondary coolant was monitored for beta-gamma activity. Leakage to the secondary coolant was a minor pathway compared to release from the tube storage basins.

Similar pathways occurred when irradiated materials were cooled in the VTS basin and were subsequently handled in the disassembly basin. Fission products escaped to basin water from cladding microdefects or by leaching from the exposed irradiated material in failed elements. Water also leached adsorbed fission products from the exterior surfaces of fuel and targets. Once in the basin water, they circulated with the water, and most of them became trapped in the deionizer. Again, low temperatures minimized the airborne release of fission products from the VTS. 
Continuous purging of the VTS basin water was the primary pathway by which aqueous fission products were released to the environment. Initially, VTS basin waters were purged directly to site streams to remove the heat generated by the stored irradiated fuel and targets and to maintain clarity in the storage basins. After basin heat exchangers, deionizers, and filters were installed in the 1960 s, the volume of purged water decreased significantly, as did the releases of radioactivity.

Periodic purges were performed to reduce tritium, which when accumulated resulted in exposure to operating personnel. Purges were discharged to earthen seepage basins as well as to streams. When discharged to streams, the purged water became diluted with much larger volumes of secondary cooling water. Reactor basin discharges to site streams ceased in 1978.

A source of wastewater that had low potential for containing fission products was the reactor process sewer system. This system received cooling water principally from the shell side of heat exchangers for reactor basins and other miscellaneous process waters. Process sewer water was sampled periodically and analyzed for radionuclides.

Other wastewater was collected in process sumps at the reactor facilities. Occasionally, the wastewater contained moderator from leaks that developed during reactor operations or spills that occurred when lines were broken during maintenance. The wastewater was collected and analyzed for radionuclides and moderator content. Possible disposition methods, depending on analysis results, included processing through the D-Area Heavy Water Rework Facility, through the waste evaporators in the separations areas, or discharge to seepage basins or streams.

The only known mechanism for releasing selected fission products to the atmosphere was when particles were resuspended in air when moderator evaporated after a leak or spill. Air in the process ventilation system first passed through a HEPA filter designed to remove particulates, then was exhausted to the atmospheric environment from a 61-meter stack. However, during periods when the reactor was shut down for repairs, maintenance, or to replace fuel and targets, air from reactor building levels that were 6 and 12 meters below grade elevation was allowed to bypass the filter beds enroute to the stack. This bypass occurred because a large air flow was required to remove tritium from process areas where work was performed. The capacity of the HEPA filters was insufficient to handle an air flow that was two to three times greater than normal for an extended period of time. All the air exiting the building via the stacks, however, was monitored for gross beta-gamma activity, whether or not it passed through the filter compartments. The potential for atmospheric releases of selected fission products was so small that specific analyses were not performed.

\section{Emission Control}

In the reactor areas, procedural changes were implemented to reduce releases. Provisions were made in 1963 to recirculate basin water through heat exchangers to be cooled and deionized to remove radionuclides (except tritium); this reduced discharge volumes considerably. Before 1963, basin water was purged continuously to site streams. Although the deionizers were effective in removing particulates, permanent sand filters were installed in the late 1960 s to maintain water clarity. The residues collected on the sand filters were transported to F Area to be processed and stored in waste tanks. Spent deionizer resin was transported to $\mathrm{H}$ Area for regeneration.

Under normal operating conditions, moderator and some residual radionuclides adhered to fuel and target surfaces when removed from the reactor core. In the late 1960s, element flushing during the discharge process was implemented to reduce the adhesion of radioactive material. The flushing removed most of the adhered moderator and some residual radionuclides (such as fission products). After flushing, the elements were stored in the VTS, and the flush water was collected in drums for treatment in the Heavy Water Rework Facility.

Atmospheric releases were minimized by using a confinement system intended not only for routine operations but for a reactor incident. The system consists of a demister filter bank, a particulate HEPA filter bank, and a carbon filter bank to remove radioiodine.

\section{Release Monitoring}

Reactor stack air was continuously sampled for particulate radioactivity. Because of the very low level of airborne fission products in the reactor exhaust air, specific analyses for the radionuclides discussed in this document were not performed routinely.

Several techniques were used to monitor aqueous releases. Cooling water was monitored for beta-gamma activity, and specific analyses for fission products were performed. Basin purge water has been analyzed routinely in the laboratory since the mid 1950s.

\section{History of Measured Releases}

Aqueous releases from each reactor have decreased significantly over the years of operation. Typically, a small fraction of the total aqueous releases of fission products from a given reactor occurred after recirculation of VTS basin water through sand filters began in the 1970s. The greatest measured aqueous releases of fission products 
from reactors occurred during the 1960s (Cummins et al. 1991).

\section{Reactor}

C Reactor was operational from 1955 until it was shut down for extensive maintenance in 1985. As of 1996, it is permanently shut down. Reactor basin purges were discharged into Fourmile Branch and three seepage basins, designated $904-66 \mathrm{G},-67 \mathrm{G}$, and $-68 \mathrm{G}$. The seepage basins were used from 1959 to 1970 and again from 1978 to 1986. Releases to stream and seepage basins from C Area are presented in Figures 3.2 and 3.3 and in Table 3-1.

The total measured aqueous releases from $\mathrm{C}$ Reactor to Fourmile Branch during the reactor's operational lifetime were $1.8 \times 10^{1} \mathrm{Ci}$ of ${ }^{95} \mathrm{Zr}, \mathrm{Nb} ; 5.6 \times 10^{0} \mathrm{Ci}$ of ${ }^{106} \mathrm{Ru}$, and $4.0 \times 10^{1} \mathrm{Ci}$ of ${ }^{144} \mathrm{Ce}$. Cumulative releases to seepage basins totaled $6.5 \times 10^{0} \mathrm{Ci}$ of ${ }^{95} \mathrm{Zr}, \mathrm{Nb} ; 3.0 \times 10^{\circ} \mathrm{Ci}$ of ${ }^{106} \mathrm{Ru}$; and $4.0 \times 10^{-1} \mathrm{Ci}$ of ${ }^{144} \mathrm{Ce}$. The greatest annual release of ${ }^{95} \mathrm{Zr}, \mathrm{Nb}$ to Fourmile Branch, $5.8 \times 10^{\circ} \mathrm{Ci}$, occurred in 1967; of ${ }^{106} \mathrm{Ru}, 9.0 \times 10^{-1} \mathrm{Ci}$, in 1961; and of ${ }^{144} \mathrm{Ce}, 1.4 \times 10^{1} \mathrm{Ci}$, in 1968. Discharges of treated liquid purges of the VTS basins have been directed to the seepage basins since 1982.

\section{K Reactor}

K Reactor was operational from 1954 until it was placed in a standby mode in 1988, restarted briefly in 1992, then returned to standby status. Reactor cooling basin purges were discharged to Pen Branch and to two earthen basins outside the building-one designated 904-65G and the other designated 904-88G. Because basin 904-65G had poor seepage characteristics, it received disassembly basin purges only in 1959 and 1965 . Basin 904-88G was used to receive disassembly basin purges and occasional miscellaneous wastewater discharges from 1965 to 1989. Releases to stream and seepage basins from $\mathrm{K}$ Area are presented in Figures 3.4 and 3.5 and in Table 3-2.

An atmospheric release was recorded only in 1990 and was $3.1 \times 10^{-5} \mathrm{Ci}$ of $106 \mathrm{Ru}$. The total measured aqueous releases from $\mathrm{K}$ Reactor to Pen Branch during the reactor's operational lifetime were $1.6 \times 10^{1} \mathrm{Ci}$ of ${ }^{95} \mathrm{Zr}, \mathrm{Nb} ; 1.1 \times$ $10^{1} \mathrm{Ci}$ of ${ }^{106} \mathrm{Ru}$; and $6.5 \times 10^{1} \mathrm{Ci}$ of ${ }^{144} \mathrm{Ce}$. Cumulative releases to seepage basins totaled $1.3 \times 10^{1} \mathrm{Ci}$ of ${ }^{95} \mathrm{Zr}, \mathrm{Nb}$; $5.0 \times 10^{0} \mathrm{Ci}$ of ${ }^{106} \mathrm{R}$; and $4.6 \times 10^{1} \mathrm{Ci}$ of ${ }^{144} \mathrm{Ce}$. The greatest annual release of ${ }^{95} \mathrm{Zr}, \mathrm{Nb}$ to Pen Branch, $5.2 \times 10^{\circ} \mathrm{Ci}$, occurred in 1968; of ${ }^{106} \mathrm{Ru}, 2.4 \times 10^{\circ} \mathrm{Ci}$, in 1961; and of ${ }^{144} \mathrm{Ce}, 2.2 \times 10^{1} \mathrm{Ci}$, in 1960 .

\section{Reactor}

L Reactor was operational from 1954 to 1968 , when it was placed in standby. It was refurbished in the early 1980s, restarted in 1985, and operated until it was temporarily shut down in 1988. As of 1996, it is permanently shut down. L Lake was constructed by damming Steel Cresk in the early 1980 s to provide thermal mitigation of secondary cooling water from the restarted reactor's heat exchanger. Therefore, during L Reactor's second operational period, secondary cooling water from the reactor heat exchanger was discharged to L Lake, which drains into Steel Creek. Releases to stream and seepage basins from L Area are presented in Figures 3.6 and 3.7 and in Table 3-3.

Reactor basin purges were discharged to Steel Creek, L Lake, and a seepage basin designated 904-64G. The seepage basin was used intermittently in 1958, 1959, 1961 to 1965, 1967 to 1969 , and 1985 to 1989 . The L-Area Cil and Chemical Basin (904-83G) was used from 1961 to 1979 to receive wastewater containing various oils and chemicals from all the reactor areas. It is adjacent to the 904-64G seepage basin. An atmospheric release was recorded only in 1990 and was $4.0 \times 10^{-6} \mathrm{Ci}$.

The total measured aqueous releases from $\mathrm{L}$ Reactor to Steel Creek during the reactor's operational lifetime were $3.3 \times 10^{1} \mathrm{Ci}$ of ${ }^{95} \mathrm{Zr}, \mathrm{Nb} ; 1.6 \times 10^{1} \mathrm{Ci}$ of ${ }^{106} \mathrm{Ru}$; and $1.6 \times$ $10^{2} \mathrm{Ci}$ of ${ }^{144} \mathrm{Ce}$. Cumulative releases to seepage basins totaled $3.0 \times 10^{1} \mathrm{Ci}$ of ${ }^{95} \mathrm{Zr}, \mathrm{Nb} ; 3.6 \times 10^{1} \mathrm{Ci}$ of ${ }^{906} \mathrm{R}$; anld $7.8 \times 10^{0} \mathrm{Ci}$ of ${ }^{144} \mathrm{Ce}$. The greatest annual release of ${ }^{95} \mathrm{Zr}, \mathrm{Nb}$ to Steel Creek, $1.3 \times 10^{1} \mathrm{Ci}$; of ${ }^{106} \mathrm{Ru}, 5.0 \times 10^{0}$ $\mathrm{Ci}$; and of ${ }^{144} \mathrm{Ce}, 7.2 \times 10^{1} \mathrm{Ci}$, all occurred in 1964 .

\section{P Reactor}

P Reactor was operational from 1954 until it was temporarily shut down in 1988. As of 1996 , it is permanently shut down. Reactor basin purges were discharged to Steel Creek and PAR Pond from 1954 to 1956, during 1969, and from 1971 to 1977 and to three seepage basins from 1957 to 1968 , during 1970, and from 1978 to 1989 . The seepage basins have designations 904-61G, $-62 \mathrm{G}$, and -63G. Reactor cooling water and miscellaneous effluents were discharged to Steel Creek until 1963; most of the cooling water later was diverted to PAR Pond. When L Lake was constructed in the early 1980s, all aqueous effluents were diverted to PAR Pond. Releases to stream and seepage basins from P Area are presented in Figures 3.8 and 3.9 and in Table 3-4.

The total measured aqueous releases from $\mathrm{P}$ Reactor to Steel Creek/PAR Pond during the reactor's operational lifetime were $2.1 \times 10^{1} \mathrm{Ci}$ of ${ }^{95} \mathrm{Zr}, \mathrm{Nb} ; 9.4 \times 10^{0} \mathrm{Ci}$ of ${ }^{106} \mathrm{Ru}$; and $3.5 \times 10^{1} \mathrm{Ci}$ of ${ }^{144} \mathrm{Ce}$. Cumulative releases to seepage basins totaled $2.4 \times 10^{-1} \mathrm{Ci}$ of ${ }^{95} \mathrm{Zr}$, Nb; $3.5 \times 10^{-1}$ $\mathrm{Ci}$ of ${ }^{106} \mathrm{Ru}$; and $2.4 \times 10^{-1} \mathrm{Ci}$ of ${ }^{144} \mathrm{Ce}$. The greatest annual release of ${ }^{95} \mathrm{Zr}, \mathrm{Nb}$ to Steel Creek, $9.5 \times 10^{8} \mathrm{Ci}$; of ${ }^{106} \mathrm{Ru}, 4.4 \times 10^{0} \mathrm{Ci}$; and of ${ }^{144} \mathrm{Ce}, 1.2 \times 10^{1} \mathrm{Ci}$, all occurred in 1962. 


\section{R Reactor}

$\mathrm{R}$ Reactor was the first operational production reactor at SRS. It operated from late 1953 until 1964, when it was shut down. Reactor basin water was discharged into Lower Three Runs Creek from 1954 to 1958, into PAR Pond from 1958 to 1964 , and into a seepage basin system from 1957 to 1964. R Reactor had six seepage basins, designated 904$103 \mathrm{G},-104 \mathrm{G},-57 \mathrm{G},-58 \mathrm{G},-59 \mathrm{G}$, and $-60 \mathrm{G}$.

The original seepage basin, 904-103G, was used only from June to December 1957 . Use of this basin was terminated because of surface outcropping and leakage into an abandoned sewer. The basin was backfilled in 1958. Basins 904-104G, $-57 \mathrm{G},-58 \mathrm{G}$, and $-59 \mathrm{G}$ - in use from 1957 to 1960 -were deactivated, backfilled, and covered with asphalt in 1960. Basin 904-60G-in use from 1958 to 1964 -was backfilled in 1977.

Reactor heat exchanger cooling water and miscellaneous effluents were discharged to Lower Three Runs Creek from 1954 to 1958 . After 1958, these effluents were discharged to PAR Pond, which was constructed by the damming of Lower Three Runs Creek. Initially, R Reactor effluents were discharged directly to PAR Pond. Beginning in 1961, a canal and pond system that eventually drained into PAR Pond (Figure 3.1) replaced direct discharges into PAR Pond. Releases to stream and seepage basins from $R$ Area are presented in Figures 3.10 and 3.11 and in Table 35.

The total measured aqueous releases from $R$ Reactor to Lower Three Runs/PAR Pond during the reactor's operational lifetime were $3.6 \times 10^{1} \mathrm{Ci}$ of ${ }^{95} \mathrm{Zr}, \mathrm{Nb} ; 1.7 \times 10^{1} \mathrm{Ci}$ of ${ }^{106} \mathrm{Ru}$; and $5.1 \times 10^{1} \mathrm{Ci}$ of ${ }^{144} \mathrm{Ce}$. Cumulative releases to seepage basins totaled $1.8 \times 10^{1} \mathrm{Ci}$ of ${ }^{106} \mathrm{Ru}$ and $2.0 \times 10^{-2}$ $\mathrm{Ci}$ of ${ }^{144} \mathrm{Ce}$. The greatest annual release of ${ }^{95} \mathrm{Zr}, \mathrm{Nb}$ to Lower Three Runs/PAR Pond, $2.7 \times 10^{1} \mathrm{Ci}$; of ${ }^{106} \mathrm{Ru}, 9.3 \times$ $10^{0} \mathrm{Ci}$; and of ${ }^{144} \mathrm{Ce}, 3.4 \times 10^{1} \mathrm{Ci}$; all occurred in 1963 .

\section{Summary of Reactor Releases}

The total measured stream releases of selected fission products from reactor areas through 1994 were $1.2 \times 10^{2}$ $\mathrm{Ci}$ of ${ }^{95} \mathrm{Zr}, \mathrm{Nb} ; 5.9 \times 10^{1} \mathrm{Ci}$ of ${ }^{106} \mathrm{Ru}$; and $3.5 \times 10^{2} \mathrm{Ci}$ of ${ }^{144} \mathrm{Ce}$. The total measured basin releases were $5.0 \times 10^{1} \mathrm{Ci}$ of ${ }^{95} \mathrm{Zr}, \mathrm{Nb} ; 6.2 \times 10^{1} \mathrm{Ci}$ of ${ }^{106} \mathrm{Ru}$; and $5.4 \times 10^{1} \mathrm{Ci}$ of ${ }^{144} \mathrm{Ce}$.

\section{Separations and Liquid Waste Facilities}

Two chemical separations facilities and their associated liquid-waste storage facilities are located near the center of the Site (Figure 3.1). The two separations areas are identi- fied by the letter designations $F$ and $H$. In these areas, the products of interest from reactor irradiation are chemically separated and purified from waste products.

\section{Facility Operations}

Two chemical separations facilities were used to reprocess irradiated fuel and targets in canyon buildings (221-F and 221-H). Irradiated materials were dissolved, and the products of interest: were chemically separated and purified from waste fission and activation products. Occasional special campaigns produced radionuclides such as ${ }^{238} \mathrm{Pu}$ and ${ }^{252} \mathrm{Cf}$.

Beginning in late $1954,{ }^{239} \mathrm{Pu},{ }^{237} \mathrm{~Np}$, and ${ }^{238} \mathrm{U}$ were recovered from irradiated ${ }^{238} \mathrm{U}$ targets in $\mathrm{F}$ Area, which used the Purex chemical extraction process. In $\mathrm{H}$ Area, ${ }^{239} \mathrm{Pu}$ and ${ }^{238} \mathrm{U}$ were recovered from ${ }^{238} \mathrm{U}$ targets by the Purex process from 1955 to 1959 . The H-Area facility then was modified to recover ${ }^{235} \mathrm{U}$ from irradiated enriched uranium fuel. A further modification in 1963 allowed the recovery of ${ }^{237} \mathrm{~Np}$ from the fuel; the HM process was used for chemical extraction of the uranium. Also in $\mathrm{H}$ Area, the Frames process was used occasionally to recover ${ }^{238} \mathrm{Pu}$ and ${ }^{237} \mathrm{~Np}$ from special target elements. This process used ion exchange for separations and purification.

Waste facilities in or adjacent to the separations facilities were designed for liquid-waste handling. Depending on activity level, liquid wastes were stored in tanks or sent to seepage basins or the ETF. In November 1988, the ETF became operational to treat wastes previously sent to seepage basins that were closed in 1988 and have been decommissioned.

\section{Pathways for Release}

Unlike the reactor facilities, which released fission products to the environment almost exclusively through aqueous effluents, the separations facilities have released fission products through atmospheric and aqueous effluents. Atmospheric releases have occurred from both canyon building stacks while aqueous releases primarily went to seepage basins.

Aqueous releases occurred when residual ${ }^{95} \mathrm{Zr}, \mathrm{Nb} ;{ }^{95} \mathrm{Nb}$; ${ }^{103} \mathrm{Ru} ;{ }^{106} \mathrm{Ru} ;{ }^{141} \mathrm{Ce}$; and ${ }^{144} \mathrm{Ce}$ were present in high- and low-level aqueous waste streams. Before these wastes were stored in tanks, an evaporation process was used to reduce volume. During evaporation, part of the fission products distilled with the condensate in the evaporators. This condensate was sent to the seepage basins through November 1988, then to the ETF. 
The major sources of wastewater previously discharged to the seepage basins were the overheads from the nitric acid recovery unit and the process evaporators in F Area and $\mathrm{H}$ Area. In $\mathrm{H}$ Area, water from the Resin Regeneration Facility and RBOF also was discharged to the seepage basin system. A flow sheet for liquid waste handling can be found in Jacobsen et al. (1973). Because of this reference's date, replacement of the seepage basins with the ETF is not shown.

\section{Emission Control}

Administrative and physical controls implemented in reactor areas in the 1960 s minimized the possibility that shortcooled fuel or targets would be sent inadvertently to the chemical separations areas. Beginning. in the early 1970s, fuel and targets were controlled so their nominal cooling time was 200 days before reprocessing by the Purex or HM process.

Canyon building exhaust air passed through sand filters for removal of particulate radioactivity prior to discharge from a 61-meter stack. Air and fumes from process vessels were exhausted through a variety of scrubbers, filters, or silver nitrate reactors to remove specific gaseous contaminants before final filtration and discharge from the stack. The $61-$ meter stack in each facility provided sufficient loft to the offgases to ensure that fission products (and other radionuclides) were dissipated into very low concentrations over a large area. This minimized exposure to people in and around the facility.

For liquid releases, results of radioactivity measurements determined whether liquids were discharged to the ETF (previously seepage basins) or to waste tanks.

\section{Release Monitoring}

Atmospheric releases of fission products from separations facilities have been sampled since startup. Irradiated material reprocessing began in F Canyon in November 1954 and in H Canyon in July 1955. Fission products that were not specifically identified contributed to the unidentified beta portion of releases.

Aqueous releases of selected fission products to seepage basins have been quantified. Several techniques were used to monitor aqueous releases. Process cooling water in $\mathrm{F}$ Area was monitored in-line for beta-gamma activity. In $\mathrm{H}$ Area, batches of process cooling water were monitored prior to release. When liquid effluents were released to seepage basins, they were sampled continuously. Samples were collected weekly and analyzed by gamma spectrometry. ETF discharges were sampled prior to release to Upper Three Runs Creek (Taylor 1989).

\section{History of Measured Releases}

Atmospheric releases of radioactivity, as well as releases to streams and seepage basins, have been monitored since the startup of the chemical separations facilities (Cummins et al. 1991). In some years, selected fission products were not quantified individually, but their radioactivity was included in unidentified beta-gamma activity.

\section{F-Area Separations}

Aqueous wastes from F Canyon initially were sent to waste tanks and to a seepage basin designated 90449G, also known as Old F-Area Seepage Basin. The capacity of this basin proved to be inadequate, and it was abandoned in 1955, after three additional seepage basins were constructed. The new basins, designated $904-41 G,-42 G$, and $-43 G$, were in use from 1955 to 1988, when wastewaters were diverted to the ETF. The latter basins also were known as F-Seepage Basins 1, 2, and 3.

Additionally, an earthen retention basin (281-3F) was used from 1955 to 1973 for the temporary containment of water potentially contaminated by process upsets. Use of a lined retention basin was implemented in 1973.

\section{Releases to Atmosphere}

Selected fission products were measured in atmospheric releases from $\mathrm{F}$ Area. The releases of ${ }^{95} \mathrm{Zr}, \mathrm{Nb}$ totaled $1.6 \times 10^{0} \mathrm{Ci} ;{ }^{95} \mathrm{Nb}, 6.9 \times 10^{-1} \mathrm{Ci} ;{ }^{103} \mathrm{Ru}, 9.7 \times$ $10^{-1} \mathrm{Ci} ;{ }^{106} \mathrm{Ru}, 7.1 \times 10^{1} \mathrm{Ci} ;{ }^{141} \mathrm{Ce}, 1.0 \times 10^{-2} \mathrm{Ci}$; and ${ }^{144} \mathrm{Ce}, 1.2 \times 10^{\circ} \mathrm{Ci}$. The largest release of ${ }^{95} \mathrm{Zr}, \mathrm{Nb}$ totaled $2.5 \times 10^{-1} \mathrm{Ci}$ in $1961 ;{ }^{95} \mathrm{Nb}, 2.3 \times 10^{-1} \mathrm{Ci}$ in $1971 ;{ }^{103} \mathrm{Ru}, 8.0 \times 10^{-1} \mathrm{Ci}$ in $1978 ;{ }^{106} \mathrm{Ru}, 3.2 \times 10^{1} \mathrm{Ci}$ in $1978 ;{ }^{141} \mathrm{Ce}, 3.6 \times 10^{-3} \mathrm{Ci}$ in 1985 ; and ${ }^{144} \mathrm{Ce}, 1.8 \times$ $10^{-1} \mathrm{Ci}$ in 1964. Measured annual releases are shown in Figures 3.12 through 3.14 and in Table 3-6.

\section{Ruthenium Release Incident}

An estimated 32 curies of ${ }^{106}$ Ru was released November 6, 1978, from the dissolver offgas stack (Pendergast and Weber 1979). Dissolving a new type of target, Mark $41 \mathrm{PuO}_{2}$-Al, began October 26, 1978, in the 221-F canyon building. The targets were dissolved in a mixture of boiling nitric acid, mercuric nitrate, and potassium fluoride. When the dissolution was complete, solids, believed to be plutonium oxide, remained in the vessel. Nitric acid and potassium fluoride were added, and the solution was heated to $105^{\circ} \mathrm{C}$ for 4 hours in an attempt to dissolve the remaining solids. Ruthenium-106 was volatilized, released through the offgas stack, and detected when a 
Health Physics employee found his shoes contaminated (Chostner 1978). A subsequent survey found widespread contamination on the ground in a northeasterly direction from the canyon building (Banks 1978).

The offgas stack, attached to the 291-F stack, had no continuous radiation monitoring equipment, although the 291$F$ stack was well instrumented. Both stacks were 61 meters tall and located near the center of $F$ Area. The quantity of ${ }^{106} \mathrm{Ru}$ was estimated using environmental monitoring and meteorological data, including ground deposition, data from perimeter air monitoring stations, and data from two offsite monitoring stations (Pendergast and Weber 1979).

\section{Releases to Streams}

Cooling water for portions of the F-Area separations process is pumped from deep wells and discharged to Fourmile Branch after use. This water was in the "once through" or "segregated" cooling-water systems that controled temperatures in the separations process or waste evaporators. Because of the possibility of cooling-coil leakage, these cooling-water streams had the potential to contain measurable amounts of radioactivity. Cooling coils were used in the head-end dissolvers; hence, a mixture of many fission products was available as a potential cooling system contaminant.

To minimize releases of radioactivity into the cooling system when a leak occurred, positive pressure was maintained in the cooling coils in all process vessels. After the water had been used, it was monitored and released to Fourmile Branch. Should activity levels in the water precluded the discharge of the water to the creek, the contaminated water was held in a plastic-lined "diversion" basin and transferred to either the H-Area waste tank farm or the ETF for processing. In the past, diversion basin water that was too radioactive for release to the stream was pumped to the seepage basins. None of the selected fission products were identified as constituents of the releases from F Area to stream.

\section{Releases to F-Area Seepage Basins}

Selected fission products frequently were listed in reports of releases to basins. The releases of ${ }^{95} \mathrm{Zr}, \mathrm{Nb}$ totaled $5.1 \times$ $10^{2} \mathrm{Ci} ;{ }^{95} \mathrm{Nb}, 5.4 \times 10^{1} \mathrm{Ci} ;{ }^{103} \mathrm{Ru}, 1.8 \times 10^{1} \mathrm{Ci} ;{ }^{106} \mathrm{Ru}, 1.1 \times$ $10^{3} \mathrm{Ci} ;{ }^{141} \mathrm{Ce}, 7.1 \times 10^{-2} \mathrm{Ci}$, and ${ }^{144} \mathrm{Ce}, 2.1 \times 10^{2} \mathrm{Ci}$. The largest release of ${ }^{95} \mathrm{Zr}, \mathrm{Nb}$ was $1.5 \times 10^{2} \mathrm{Ci}$ in $1960 ;{ }^{95} \mathrm{Nb}$, $1.0 \times 10^{1} \mathrm{Ci}$ in $1973 ;{ }^{103} \mathrm{Ru}, 2.2 \times 10^{0} \mathrm{Ci}$ in $1973 ;{ }^{106} \mathrm{Ru}$, $2.0 \times 10^{2} \mathrm{Ci}$ in $1964 ;{ }^{141} \mathrm{Ce}, 4.0 \times 10^{-2} \mathrm{Ci}$ in 1972 ; and ${ }^{144} \mathrm{Ce}, 7.8 \times 10^{1} \mathrm{Ci}$ in 1960 . Releases for individual years are shown in Figures 3.15 through 3.17 and in Table 3-6.

\section{H-Area Separations}

H Canyon has been operational since July 1955 . In addition to the general chemical separations operations, $H$ Area also includes the ETF and the RBOF, with an adjacent regeneration facility for resins from other areas. Certain offsite non-commercial irradiated fuels are stored underwater in the RBOF, as are some SRS fuel elements that have failed. This facility is equipped to disassemble and cut fuel for inspection.

Aqueous wastes from $\mathrm{H}$ Canyon were sent to tanks and to four seepage basins, designated $904-44 \mathrm{G},-45 \mathrm{G},-46 \mathrm{G}$, and $-56 \mathrm{G}$. The basins, also known as H- Seepage Basins 1, 2, 3 , and 4, were used from 1955 to 1988 , when wastewaters were diverted to the ETF. Basin 904-46G has been inactive since 1962.

Also, an earthen retention basin, designated 281-3H, was used from 1955 to 1973 to temporarily contain water potentially contaminated by process upsets. Use of a lined retention basin was implemented in 1973.

\section{Releases to Atmosphere}

Selected fission products were measured in atmospheric releases from $\mathrm{H}$ Area. The releases of ${ }^{95} \mathrm{Zr}, \mathrm{Nb}$ totaled 1.6 $\times 10^{0} \mathrm{Ci} ;{ }^{95} \mathrm{Nb}, 3.9 \times 10^{-1} \mathrm{Ci} ;{ }^{103} \mathrm{Ru}, 1.8 \times 10^{1} \mathrm{Ci} ;{ }^{106} \mathrm{Ru}$, $6.8 \times 10^{1} \mathrm{Ci} ;{ }^{141} \mathrm{Ce}, 3.6 \times 10^{-2} \mathrm{Ci}$; and ${ }^{144} \mathrm{Ce}, 3.0 \times 10^{0} \mathrm{Ci}$. The largest release of ${ }^{95} \mathrm{Zr}, \mathrm{Nb}$ totaled $2.4 \times 10^{-1} \mathrm{Ci}$ in $1970 ;{ }^{99} \mathrm{Nb}, 1.7 \times 10^{-1} \mathrm{Ci}$ in $1972 ;{ }^{103} \mathrm{Ru}, 9.5 \times 10^{0} \mathrm{Ci}$ in $1969 ;{ }^{106} \mathrm{Ru}, 2.0 \times 10^{1} \mathrm{Ci}$ in $1968 ;{ }^{141} \mathrm{Ce}, 1.9 \times 10^{-2} \mathrm{Ci}$ in 1971; and ${ }^{144} \mathrm{Ce}, 7.8 \times 10^{-1} \mathrm{Ci}$ in 1969 . Measured annual releases are shown in Figures 3.18 through 3.20 and in Table 3-7.

\section{Releases to Streams}

As in F Area, clean well water was pumped through pressurized coils in evaporators and process tanks to control temperatures, then discharged to a process sewer that empties into Fourmile Branch. Water from the cooling system was monitored before release to Fourmile Branch. No release of selected fission product activity has been reported except for very small amounts in 1989 , when 5.5 $\times 10^{-5} \mathrm{Ci}$ of ${ }^{95} \mathrm{Zr}, \mathrm{Nb} ; 4.7 \times 10^{-3} \mathrm{Ci}$ of ${ }^{106} \mathrm{Ru}$; and $4.5 \times 10^{-5}$ $\mathrm{Ci}$ of ${ }^{144} \mathrm{Ce}$ were released.

\section{Releases to H-Area Seepage Basins}

Selected fission products frequently were listed in reports of releases to basins. The releases of ${ }^{95} \mathrm{Zr}, \mathrm{Nb}$ totaled $2.1 \times$ $10^{2} \mathrm{Ci} ;{ }^{95} \mathrm{Nb}, 1.3 \times 10^{1} \mathrm{Ci} ;{ }^{103} \mathrm{Ru}, 1.5 \times 10^{1} \mathrm{Ci} ;{ }^{106} \mathrm{Ru}, 5.6$ $\times 10^{2} \mathrm{Ci}$; ${ }^{141} \mathrm{Ce}, 2.7 \times 10^{\circ} \mathrm{Ci}$, and ${ }^{144} \mathrm{Ce}, 9.2 \times 10^{1} \mathrm{Ci}$. The largest release of ${ }^{95} \mathrm{Zr}, \mathrm{Nb}$ was $4.1 \times 10^{1} \mathrm{Ci}$ in $1964 ;{ }^{95} \mathrm{Nb}$, $5.0 \times 10^{\circ} \mathrm{Ci}$ in $1972 ;{ }^{103} \mathrm{Ru}, 5.2 \times 10^{\circ} \mathrm{Ci}$ in $1971 ;{ }^{106} \mathrm{Ru}$, 
$8.9 \times 10^{1} \mathrm{Ci}$ in $1959 ;{ }^{141} \mathrm{Ce}, 1.2 \times 10^{\circ} \mathrm{Ci}$ in 1973 ; and ${ }^{144} \mathrm{Ce}, 2.5 \times 10^{1} \mathrm{Ci}$ in 1979 . Measured annual releases are shown in Figures 3.21 through 3.23 and in Table 3-7.

\section{Effluent Treatment Facility}

The ETF became operational in November 1988 to receive aqueous wastes that had previously been discharged to the separations area seepage basins. Treated aqueous wastes from the ETF are discharged to Upper Three Runs Creek.

\section{Waste Tank Farms}

High-level, radioactive, liquid-waste storage tanks, located in F Area and $\mathrm{H}$ Area, received selected fission products after separation in the canyon buildings. However, because of the relatively short half-lives, the current quantities are insignificant when compared to longer-lived radionuclides such as ${ }^{137} \mathrm{Cs}$ and ${ }^{90} \mathrm{Sr}$.

\section{Summary of Separations}

and Liquid Waste Facilities

The total measured atmospheric releases of selected fission products from the separations areas through 1994 were $3.2 \times 10^{\circ} \mathrm{Ci}$ of ${ }^{95} \mathrm{Zr}, \mathrm{Nb} ; 1.1 \times 10^{0} \mathrm{Ci}$ of ${ }^{95} \mathrm{Nb} ; 1.9 \times$ $10^{1} \mathrm{Ci}$ of ${ }^{103} \mathrm{Ru}, 1.4 \times 10^{2} \mathrm{Ci}$ of ${ }^{106} \mathrm{Ru} ; 4.6 \times 10^{-2} \mathrm{Ci}$ of ${ }^{141} \mathrm{C}$; and $4.2 \times 10^{\circ} \mathrm{Ci}$ of ${ }^{144} \mathrm{Ce}$. Stream releases were reported only in one year and were small. The total measured basin releases were $7.2 \times 10^{2} \mathrm{Ci}$ of ${ }^{95} \mathrm{Zr}, \mathrm{Nb} ; 6.7 \times$ $10^{1} \mathrm{Ci}$ of ${ }^{95} \mathrm{Nb} ; 3.3 \times 10^{1} \mathrm{Ci}$ of ${ }^{103} \mathrm{Rb} ; 1.7 \times 10^{3} \mathrm{Ci}$ of ${ }^{106} \mathrm{Ru} ; 2.8 \times 10^{\circ} \mathrm{Ci}$ of ${ }^{141} \mathrm{C}$; and $3.0 \times 10^{2} \mathrm{Ci}$ of ${ }^{144} \mathrm{Ce}$.

\section{Solid Waste Disposal Facility}

Radioactive solid wastes generated during SRS operations have been burned in low-level waste incinerators or buried in the SWDF. Because of the nature of much of the waste, precise analysis of the radioactive inventory of materials committed to the SWDF is not available. However, the radioactivity of the relatively short half-life selected fission products is much less than the radioactivity of other fission products such as ${ }^{137} \mathrm{Cs}$ and ${ }^{90} \mathrm{Sr}$.

\section{Savannah River Technology Center}

The Savannah River Technology Center provided research and development support for the production facilities of SRS. Laboratory facilities handled radioactivity that ranged from environmental levels to highly radioactive materials-the latter manipulated in shielded cells.

Liquid radioactive wastes were accumulated in holding tanks pending shipment to F Area for treatment and disposition.

From 1954 to 1982, a seepage basin system was used for low-activity wastes. The first two seepage basins, both designated 904-53G, were put in service in 1954. The last two, 904-54G and -55G, were added in 1958 and 1960 , respectively. There is no record of selected fission product releases to atmosphere, streams, or basins.

\section{Other Facilities}

A number of other facilities handled materials containing fission products. These were the test reactors, the Heavy Water Rework Facility, and any facility handling spontaneously fissioning elements.

No releases of fission products were documented for any of the test reactors described in Chapter 2. Had there been releases from these facilities, they would have been small compared to those from production reactors. Operation of these test reactors was discontinued in the 1970 s.

The Heavy Water Rework Facility, located in D Area, consisted of four distillation towers and associated equipment for removal of ordinary water that accumulated in the heavy water moderator used in the reactors. Leaks in the system were vented through a 21 meter stack. The aqueous waste stream was sent to Beaver Dam Creek after verification that activity levels did not exceed specific limits. The predominant radioactivity associated with this facility was tritium.

Potential existed for traces of selected fission products to be present in the moderator, as was described in the section on reactor facilities. Releases totaled $4.0 \times 10^{\circ}$ Ci of ${ }^{95} \mathrm{Zr}$. $; 4.1 \times 10^{-1} \mathrm{Ci}$ of ${ }^{106} \mathrm{Ru}$; and $2.7 \times 10^{-1} \mathrm{Ci}$ of ${ }^{144} \mathrm{Ce}$. The annual releases are shown in Table 3-8.

Central Shops (N Area) at SRS fabricated and repaired equipment used in the separations and reactor areas of the Site. Though equipment was decontaminated before it was sent to Central Shops, some radioactive material occasionally was present and normally removed during cleaning before the equipment repair. The contamination was transferred with other liquid waste streams to a seepage basin. No selected fission product releases have been recorded.

Facilities other than those already described in this chapter that handled spontaneously fissioning elements were the reactor material facilities for uranium fuel and target fabrication in M Area; the TNX Semiworks, where various processes were tested on a pilot scale with uranium; and the Naval Fuels Facility, where uranium fuel for the U.S. Navy was fabricated during the late 1980s. The presence of low levels of selected fission products that are attributable to spontaneous fission had no impact on the environment and is of acadernic interest only. 


\section{References for Chapter 3}

Banks, J. J., 1978, Final Report of Special Hazards Investigation No. 335, E. I. duPont De Nemours \& Co., Aiken, SC.

Chostner, D. F., 1978, Release of Ruthenium from 6.1 Dissolver Off-gas Stack, DPSPU-78-272-195, E. I. duPont De Nemours \& Co., Aiken, SC.

Cummins, C. L., C. S. Hetrick, and D. K. Martin, 1991, Radioactive Releases at the Savannah River Site 1954-t989, WSRC-RP-91-684, Westinghouse Savannah River Company, Aiken, SC.

Jacobsen, W. R., W. L. Marter, D. A. Orth, and C. P. Ross, 1973, Control and Treatment of Radioactive Liquid Waste Effluents at the Savannah River Plant, DP1349, E. I. duPont de Nemours and Company, Aiken, SC.

Pendergast, M. M., and A. H. Weber, 1979, Source Term Estimations of the Ruthenium Release November 6, 1978, DPST-79-208, E. I. duPont De Nemours \& Co., Aiken, SC.

Taylor, R.W., 1989, Effluent Treatment Facility Emissions Monitoring, DPST-89-309, E. I. du Pont de Nemours and Company, Aiken, SC. 
Table 3-1. C-Area Releases

Releases to Streams (Ci)

Releases to Basins (Ci)

\begin{tabular}{|c|c|c|c|c|c|c|}
\hline Year & $\mathrm{Zr}, \mathrm{Nb}-95$ & Ru-106 & Ce-144 & $\mathrm{Zr}, \mathrm{Nb}-95$ & $\mathrm{Ru}-106$ & Ce-144 \\
\hline 1954 & & & & & & \\
\hline 1955 & & $2.0 \times 10^{-2}$ & & & & \\
\hline 1956 & & $1.8 \times 10^{-2}$ & & & & \\
\hline 1957 & & $3.3 \times 10^{-2}$ & & & & \\
\hline 1958 & & $6.2 \times 10^{-2}$ & & & & \\
\hline 1959 & & $6.9 \times 10^{-1}$ & & & $2.2 \times 10^{-1}$ & \\
\hline 1960 & $8.5 \times 10^{-1}$ & $4.9 \times 10^{-1}$ & $3.5 \times 10^{0}$ & & $1.0 \times 10^{-2}$ & \\
\hline 1961 & $1.3 \times 10^{0}$ & $9.0 \times 10^{-1}$ & $5.9 \times 10^{0}$ & & $3.0 \times 10^{-2}$ & \\
\hline 1962 & $9.8 \times 10^{-1}$ & $3.3 \times 10^{-1}$ & $3.9 \times 10^{-1}$ & & $5.9 \times 10^{-3}$ & \\
\hline 1963 & $7.0 \times 10^{-1}$ & $3.3 \times 10^{-1}$ & $2.5 \times 10^{0}$ & & $7.4 \times 10^{-2}$ & \\
\hline 1964 & $1.1 \times 10^{0}$ & $5.1 \times 10^{-1}$ & $2.5 \times 10^{0}$ & $1.4 \times 10^{0}$ & $1.2 \times 10^{0}$ & $2.5 \times 10^{-1}$ \\
\hline 1965 & $4.5 \times 10^{-1}$ & $7.9 \times 10^{-1}$ & $1.2 \times 10^{0}$ & $1.2 \times 10^{0}$ & $7.9 \times 10^{-1}$ & $2.0 \times 10^{-2}$ \\
\hline 1966 & $1.4 \times 10^{0}$ & $2.9 \times 10^{-1}$ & $7.8 \times 10^{-1}$ & $1.4 \times 10^{0}$ & $4.2 \times 10^{-1}$ & $4.0 \times 10^{-3}$ \\
\hline 1967 & $5.8 \times 10^{0}$ & $3.3 \times 10^{-1}$ & $2.6 \times 10^{0}$ & $2.5 \times 10^{0}$ & $2.0 \times 10^{-1}$ & \\
\hline 1968 & $2.0 \times 10^{0}$ & $5.7 \times 10^{-1}$ & $1.4 \times 10^{1}$ & $4.0 \times 10^{-3}$ & $3.0 \times 10^{-3}$ & $2.0 \times 10^{-2}$ \\
\hline 1969 & $4.1 \times 10^{-1}$ & $1.0 \times 10^{-1}$ & $1.7 \times 10^{0}$ & & & \\
\hline 1970 & $2.2 \times 10^{0}$ & $6.0 \times 10^{-2}$ & $2.3 \times 10^{0}$ & $1.0 \times 10^{-2}$ & & $6.0 \times 10^{-2}$ \\
\hline 1971 & $8.0 \times 10^{-1}$ & $1.0 \times 10^{-2}$ & $2.4 \times 10^{0}$ & & & \\
\hline 1972 & $2.0 \times 10^{-2}$ & & $1.0 \times 10.2$ & & & \\
\hline 1973 & $4.6 \times 10^{-2}$ & $2.4 \times 10^{-2}$ & $4.2 \times 10^{-2}$ & & & \\
\hline 1974 & $1.5 \times 10^{-1}$ & $3.0 \times 10^{-3}$ & $1.3 \times 10^{-1}$ & & & \\
\hline 1975 & $1.2 \times 10^{-2}$ & & $3.0 \times 10^{-3}$ & & & \\
\hline 1976 & $1.7 \times 10^{-2}$ & $1.0 \times 10^{-3}$ & $7.0 \times 10^{-3}$ & & & \\
\hline 1977 & $1.5 \times 10^{-4}$ & $8.7 \times 10^{-4}$ & $1.3 \times 10^{-4}$ & & & \\
\hline 1978 & $3.5 \times 10^{-4}$ & & $2.1 \times 10^{-4}$ & & & $9.0 \times 10^{-4}$ \\
\hline 1979 & & & & & & $1.0 \times 10^{.4}$ \\
\hline 1980 & & & & $4.2 \times 10^{-3}$ & $7.3 \times 10^{-4}$ & $1.2 \times 10^{-2}$ \\
\hline 1981 & & & & $1.7 \times 10^{-4}$ & & $2.6 \times 10^{-3}$ \\
\hline 1982 & & & & $6.6 \times 10^{-4}$ & $1.7 \times 10^{-4}$ & $6.8 \times 10^{-4}$ \\
\hline 1983 & & & & $2.4 \times 10^{-3}$ & $5.4 \times 10^{-4}$ & $1.1 \times 10^{-2}$ \\
\hline 1984 & & & & 2. $1 \times 10^{-3}$ & $9.0 \times 10^{-5}$ & $7.7 \times 10^{-3}$ \\
\hline 1985 & & & & $1.3 \times 10^{-3}$ & & $1.2 \times 10^{-2}$ \\
\hline 1986 & & & & $4.3 \times 10^{-5}$ & & $2.9 \times 10^{-4}$ \\
\hline 1987 & & & & & & \\
\hline 1988 & & & & & & \\
\hline $\begin{array}{l}1989 \\
1990\end{array}$ & & & & & & \\
\hline $\begin{array}{l}1990 \\
1991\end{array}$ & & & & & & \\
\hline 1992 & & & & & & \\
\hline 1993 & & & & & & \\
\hline 1994 & & & & & & \\
\hline Total & $1.8 \times 10^{1}$ & $5.6 \times 10^{0}$ & $4.0 \times 10^{1}$ & $6.5 \times 10^{0}$ & $3.0 \times 10^{0}$ & $4.0 \times 10^{-1}$ \\
\hline
\end{tabular}


Table 3-2. K-Area Releases

Releases

$\begin{array}{lll}\text { to } & \text { Releases to Streams (Ci) Releases to Basins (Ci) }\end{array}$

(Ci)

\begin{tabular}{|c|c|c|c|c|c|c|c|}
\hline Y ear & $\mathrm{Ru}-106$ & $\mathrm{Zr}, \mathrm{Nb}-95$ & $\mathrm{Ru}-106$ & C e-144 & $\mathrm{Zr}, \mathrm{Nb}-9.5$ & Ru-106 & C e-144 \\
\hline 1954 & & & . & & & & \\
\hline 1955 & & & $1.7 \times 10^{-2}$ & & & & \\
\hline 1956 & & & $3.6 \times 10^{-2}$ & & & & \\
\hline 1957 & & & $9.8 \times 10^{-2}$ & & & & \\
\hline 1958 & & & $4.7 \times 10^{-2}$ & & & & \\
\hline 1959 & & & $3.9 \times 10^{1}$ & & & $3.0 \times 10^{-2}$ & \\
\hline 1960 & & $3.0 \times 10^{0}$ & $1.4 \times 10^{0}$ & $2.2 \times 10^{1}$ & & $4.7 \times 10^{-3}$ & \\
\hline 1961 & & $1.4 \times 10^{0}$ & $2.4 \times 10^{0}$ & $7.7 \times 10^{0}$ & & & . \\
\hline 1962 & & $1.9 \times 10^{0}$ & $7.7 \times 10^{-1}$ & $4.5 \times 10^{0}$ & & & \\
\hline 1963 & & $1.3 \times 10^{0}$ & $5.9 \times 10^{-1}$ & $1.8 \times 10^{0}$ & & & \\
\hline 1964 & & $4.2 \times 10^{-1}$ & $8.0 \times 10^{-1}$ & $2.6 \times 10^{0}$ & & & \\
\hline 1965 & & $7.7 \times 10^{-1}$ & $1.9 \times 10^{0}$ & $1.0 \times 10^{1}$ & & $1.0 \times 10^{-3}$ & $1.6 \times 10^{-1}$ \\
\hline 1966 & - & $1.2 \times 10^{-1}$ & $3.3 \times 10^{-1}$ & $4.0 \times 10^{-1}$ & & & \\
\hline 1967 & & $1.5 \times 10^{0}$ & $6.1 \times 10^{-1}$ & $3.3 \times 10^{0}$ & & & \\
\hline 1968 & & $5.2 \times 10^{0}$ & $1.3 \times 10^{0}$ & $1.3 \times 10^{1}$ & $2.2 \times 10^{0}$ & $2.0 \times 10^{0}$ & $3.3 \times 10^{1}$ \\
\hline 1969 & & & & $2.0 \times 10^{-2}$ & $1.3 \times 10^{0}$ & $1.3 \times 10^{0}$ & $7.8 \times 10^{0}$ \\
\hline 1970 & & & & & $7.4 \times 10^{0}$ & $1.7 \times 10^{0}$ & $4.3 \times 10^{0}$ \\
\hline 1971 & & $4.0 \times 10^{-4}$ & & $9.2 \times 10^{-4}$ & $3.4 \times 10^{-1}$ & $2.0 \times 10^{-2}$ & $8.0 \times 10^{-2}$ \\
\hline 1972 & & & & & $9.7 \times 10^{-1}$ & $2.0 \times 10^{-2}$ & $2.1 \times 10^{-1}$ \\
\hline 1973 & & $1.6 \times 10^{-2}$ & $2.0 \times 10^{-3}$ & $9.0 \times 10^{-3}$ & $4.7 \times 10^{-1}$ & $1.0 \times 10^{-3}$ & $1.8 \times 10^{-1}$ \\
\hline 1974 & & & & & $3.4 \times 10^{-1}$ & $1.0 \times 10^{-3}$ & $2.4 \times 10^{-1}$ \\
\hline 1975 & & & $5.2 \times 10^{-2}$ & $2.3 \times 10^{-2}$ & $3.0 \times 10^{-3}$ & & $4.0 \times 10^{-3}$ \\
\hline 1976 & & & & & $1.2 \times 10.1$ & $2.3 \times 10^{-2}$ & $6.9 \times 10.2$ \\
\hline 1977 & & $9.3 \times 10^{-2}$ & $1.6 \times 10^{-4}$ & $1.4 \times 10^{-1}$ & $8.9 \times 10^{-2}$ & $3.4 \times 10^{-3}$ & $5.8 \times 10^{-2}$ \\
\hline 1978 & & & & & $4.8 \times 10^{-2}$ & $7.3 \times 10^{-4}$ & $4.6 \times 10^{-2}$ \\
\hline 1979 & & & & & $5.8 \times 10^{-3}$ & $1.9 \times 10^{-4}$ & $2.8 \times 10^{-2}$ \\
\hline 1980 & & & & & $1.1 \times 10^{-2}$ & $1.3 \times 10^{-4}$ & $1.5 \times 10^{-2}$ \\
\hline 1981 & & & & & $5.0 \times 10^{-3}$ & $3.4 \times 10^{-4}$ & $5.4 \times 10^{-3}$ \\
\hline 1982 & & & & & $1.4 \times 10^{-4}$ & $2.3 \times 10^{-4}$ & $8.2 \times 10^{-4}$ \\
\hline 1983 & & & & & $5.7 \times 10^{-3}$ & & $2: 2 \times 10^{-3}$ \\
\hline 1984 & & & & & $2.1 \times 10^{-3}$ & $1.4 \times 10^{-4}$ & $8.7 \times 10^{-4}$ \\
\hline 1985 & & & & & $2.9 \times 10^{-2}$ & $1.0 \times 10^{-3}$ & $2.5 \times 10^{-2}$ \\
\hline 1986 & & & & & $1.5 \times 10^{-3}$ & $4.9 \times 10^{-4}$ & $6.5 \times 10^{-3}$ \\
\hline 1987 & & & & & $1.4 \times 10^{-3}$ & $4.8 \times 10^{-5}$ & $1.2 \times 10^{-3}$ \\
\hline 1988 & & & & & & & \\
\hline 1989 & & & & & - & & \\
\hline 1990 & $3.1 \times 10^{-5}$ & & & & & & \\
\hline 1991 & & & & & & & \\
\hline $\begin{array}{l}1992 \\
1993\end{array}$ & & & & & & & \\
\hline 1994 & & & & & & & \\
\hline Total & $3.1 \times 10^{-5}$ & $1.6 \times 10^{1}$ & $1.1 \times 10^{1}$ & $6.5 \times 10^{1}$ & $1.3 \times 10^{1}$ & $5.0 \times 10^{0}$ & $4.6 \times 10^{1}$ \\
\hline
\end{tabular}


Table 3-3. L-Area Releases

\begin{tabular}{|c|c|c|c|c|c|c|c|}
\hline & $\begin{array}{l}\text { Releases to } \\
\text { Atmos. (Ci) }\end{array}$ & $\mathbf{R e}$ & es to Strea & (Ci) & & eleases to & ins $(\mathbf{C} \mathbf{i})$ \\
\hline Year & $\mathrm{Ru}-106$ & $\mathrm{Zr}_{\mathbf{1}} \mathrm{Nb}-95$ & Ru-106 & Ce-144 & $\mathrm{Zr}, \mathrm{Nb}-95$ & Ru-106 & $\mathrm{Ce}-144$ \\
\hline 1954 & & & & & & & \\
\hline 1955 & & & $4.2 \times 10^{-2}$ & & & & \\
\hline 1956 & & & $7.5 \times 10^{-2}$ & & & & \\
\hline 1957 & & & $1.8 \times 10^{-1}$ & & & & \\
\hline 1958 & & & $1.6 \times 10^{-1}$ & & & $4.7 \times 10^{-2}$ & \\
\hline 1959 & & & $4.0 \times 10^{-1}$ & & & $6.0 \times 10^{-3}$ & \\
\hline 1960 & & $1.4 \times 10^{0}$ & $3.8 \times 10^{0}$ & $9.0 \times 10^{0}$ & & $8.3 \times 10^{-3}$ & \\
\hline 1961 & & $2.1 \times 10^{0}$ & $2.4 \times 10^{0}$ & $1.9 \times 10^{1}$ & & $3.9 \times 10^{-2}$ & \\
\hline 1962 & & $2.4 \times 10^{0}$ & $5.0 \times 10^{-1}$ & $3.3 \times 10^{0}$ & & $3.2 \times 10^{-2}$ & \\
\hline 1963 & & $1.1 \times 10^{0}$ & $8.7 \times 10^{-1}$ & $6.5 \times 10^{0}$ & & $4.4 \times 10^{-1}$ & \\
\hline 1964 & & $1.3 \times 10^{1}$ & $5.0 \times 10^{0}$ & $7.2 \times 10^{1}$ & $1.0 \times 10^{1}$ & $3.9 \times 10^{0}$ & $3.2 \times 10^{0}$ \\
\hline 1965 & & $4.3 \times 10^{0}$ & $1.1 \times 10^{0}$ & $1.9 \times 10^{1}$ & $5.9 \times 10^{0}$ & $2.9 \times 10^{1}$ & $2.1 \times 10^{0}$ \\
\hline 1966 & & $5.8 \times 10^{0}$ & $6.5 \times 10^{-1}$ & $1.8 \times 10^{1}$ & $6.4 \times 10^{0}$ & $1.7 \times 10^{0}$ & $1.1 \times 10^{0}$ \\
\hline 1967 & & $2.3 \times 10^{0}$ & $7.1 \times 10^{-1}$ & $1.0 \times 10^{1}$ & $5.2 \times 10^{0}$ & $8.1 \times 10^{-1}$ & $9.0 \times 10^{-1}$ \\
\hline 1968 & & $3.3 \times 10^{-1}$ & & $3.6 \times 10^{0}$ & $2.0 \times 10^{0}$ & $1.2 \times 10^{-1}$ & $4.5 \times 10^{-1}$ \\
\hline 1969 & & & & $2.7 \times 10^{-1}$ & $8.0 \times 10^{-3}$ & $1.0 \times 10^{-3}$ & $1.1 \times 10^{-2}$ \\
\hline 1970 & & & & & $4.0 \times 10^{-3}$ & $1.0 \times 10^{-3}$ & $2.0 \times 10^{-3}$ \\
\hline 1971 & & & & & $2.0 \times 10^{-3}$ & $1.0 \times 10^{-3}$ & $4.0 \times 10^{-3}$ \\
\hline 1972 & & & & & $2.2 \times 10^{-1}$ & $2.0 \times 10^{-2}$ & $9.0 \times 10^{-2}$ \\
\hline 1973 & & & & & & & \\
\hline 1974 & & & & & & & \\
\hline 1975 & & & & & $4.0 \times 10^{-3}$ & $2.0 \times 10^{-3}$ & $1.0 \times 10^{-3}$ \\
\hline 1976 & & & & & & & \\
\hline 1977 & & & & & & $3.3 \times 10^{-4}$ & $2.3 \times 10^{-4}$ \\
\hline 1978 & & & & & & & \\
\hline 1979 & & & & & & & \\
\hline 1980 & & & & & & & \\
\hline 1981 & & & & & & & \\
\hline 1982 & & & & & & & \\
\hline 1983 & & & & & & & \\
\hline 1984 & & & & & & & \\
\hline 1985 & & & & & & $1.6 \times 10^{-4}$ & $2.7 \times 10^{-5}$ \\
\hline 1986 & & & & & & $2.9 \times 10^{-6}$ & \\
\hline 1987 & & & & & & & \\
\hline 1988 & & & & & & & \\
\hline 1989 & & & & & & & $1.9 \times 10^{-5}$ \\
\hline 1990 & & & & & & & \\
\hline 1991 & & & & & & & \\
\hline 1992 & & & & & & & \\
\hline 1993 & $4.0 \times 10^{-6}$ & & & & & $\vdots$ & \\
\hline 1994 & & & & & & & \\
\hline Total & $4.0 \times 10^{-6}$ & $3.3 \times 10^{1}$ & $1.6 \times 10^{1}$ & $1.6 \times 10^{2}$ & $3.0 \times 10^{1}$ & $3.6 \times 10^{1}$ & $7.8 \times 10^{0}$ \\
\hline
\end{tabular}


Table 3-4. P-Area Releases

\begin{tabular}{|c|c|c|c|c|c|c|}
\hline & \multicolumn{3}{|c|}{ Releases to Streams (Ci) } & \multicolumn{3}{|c|}{ Releases to Basins (Ci) } \\
\hline Year & $\mathrm{Zr}, \mathrm{Nb}-95$ & $\mathbf{R u}-106$ & $\mathrm{Ce}-144$ & $\mathrm{Zr}, \mathrm{Nb}-95$ & Ru-106 & $\mathrm{Ce}-144$ \\
\hline 1954 & & & & & & \\
\hline 1955 & & $4.2 \times 10^{-2}$ & & & & \\
\hline 1956 & & $9.8 \times 10^{-2}$ & & & & \\
\hline 1957 & & $2.8 \times 10^{-1}$ & & & $4.8 \times 10^{-2}$ & \\
\hline 1958 & & $1.3 \times 10^{-1}$ & & & $1.5 \times 10^{-3}$ & \\
\hline 1959 & & $1.8 \times 10^{-1}$ & & & $8.6 \times 10^{-2}$ & \\
\hline 1960 & $7.5 \times 10^{-1}$ & $1.1 \times 10^{0}$ & $2.5 \times 10^{0}$ & & $9.2 \times 10^{-2}$ & \\
\hline 1961 & $6.9 \times 10^{-1}$ & $5.8 \times 10^{-1}$ & $1.2 \times 10^{0}$ & & $5.0 \times 10^{-2}$ & \\
\hline 1962 & $9.5 \times 10^{0}$ & $4.4 \times 10^{0}$ & $1.2 \times 10^{1}$ & & $2.2 \times 10^{-2}$ & \\
\hline 1963 & $2.5 \times 10^{0}$ & $1.5 \times 10^{0}$ & $6.0 \times 10^{0}$ & & $4.5 \times 10^{-2}$ & \\
\hline 1964 & $1.5 \times 10^{0}$ & $6.3 \times 10^{-1}$ & $2.1 \times 10^{0}$ & $9.0 \times 10^{-2}$ & & $2.0 \times 10^{-2}$ \\
\hline 1965 & $6.5 \times 10^{-1}$ & $8.0 \times 10^{-2}$ & $2.3 \times 10^{0}$ & & & \\
\hline 1966 & $6.5 \times 10^{-1}$ & & $1.1 \times 10^{0}$ & & & \\
\hline 1967 & $4.4 \times 10^{-1}$ & & $6.0 \times 10^{-1}$ & & & \\
\hline 1968 & $5.4 \times 10^{-1}$ & $1.0 \times 10^{-2}$ & $3.5 \times 10^{0}$ & & & $1.2 \times 10^{-1}$ \\
\hline 1969 & $3.2 \times 10^{0}$ & $4.0 \times 10^{-1}$ & $3.5 \times 10^{0}$ & & & \\
\hline 1970 & $6.4 \times 10^{-1}$ & & $3.8 \times 10^{-1}$ & & & \\
\hline 1971 & $6.6 \times 10^{-4}$ & $4.6 \times 10^{-4}$ & $8.5 \times 10^{-4}$ & & & \\
\hline 1972 & $2.0 \times 10^{-2}$ & & & & & \\
\hline 1973 & $6.2 \times 10^{-2}$ & $4.0 \times 10^{-3}$ & $6.5 \times 10^{-2}$ & & & \\
\hline 1974 & $8.4 \times 10^{-2}$ & $1.0 \times 10^{-3}$ & $2.3 \times 10^{-2}$ & & & \\
\hline 1975 & $2.7 \times 10^{-2}$ & $2.0 \times 10^{-3}$ & $1.3 \times 10^{-2}$ & & & \\
\hline 1976 & & & $2.0 \times 10^{-3}$ & & & \\
\hline 1977 & $6.1 \times 10^{-4}$ & & $5.9 \times 10^{-4}$ & & & \\
\hline 1978 & & & $7.5 \times 10^{-4}$ & & & $7.0 \times 10^{-4}$ \\
\hline 1979 & & & & $1.3 \times 10^{-4}$ & & $6.7 \times 10^{-4}$ \\
\hline 1980 & & & & $3.9 \times 10^{-3}$ & $1.0 \times 10^{-4}$ & $1.1 \times 10^{-2}$ \\
\hline 1981 & & & & & & $2.7 \times 10^{-4}$ \\
\hline 1982 & & & & $1.1 \times 10^{-2}$ & $1.9 \times 10^{-3}$ & $6.7 \times 10^{-3}$ \\
\hline 1983 & & & & $1.2 \times 10^{-2}$ & & $9.0 \times 10^{-3}$ \\
\hline 1984 & & & & $1.1 \times 10^{-2}$ & $2.2 \times 10^{-3}$ & $5.6 \times 10^{-3}$ \\
\hline 1985 & & & & $1.0 \times 10^{-1}$ & $3.1 \times 10^{-3}$ & $5.7 \times 10^{-2}$ \\
\hline 1986 & & & & $1.4 \times 10^{-2}$ & $1.4 \times 10^{-3}$ & $9.0 \times 10^{-3}$ \\
\hline 1987 & & & & $4.8 \times 10^{-4}$ & $1.0 \times 10^{-5}$ & $8.6 \times 10^{-4}$ \\
\hline 1988 & & & & $7.5 \times 10^{-7}$ & & $2.2 \times 10^{-5}$ \\
\hline 1989 & & & & & & \\
\hline 1990 & & & & & & \\
\hline 1991 & & & & & & \\
\hline $\begin{array}{l}1992 \\
1993\end{array}$ & & & & & & 1 \\
\hline 1994 & & & & & & \\
\hline Total & $2.1 \times 10^{1}$ & $9.4 \times 10^{0}$ & $3.5 \times 10^{1}$ & $2.4 \times 10^{-1}$ & $3.5 \times 10^{-1}$ & $2.4 \times 10^{-1}$ \\
\hline
\end{tabular}


Table 3-5. R-Area Releases

Releases to Streams (Ci)

Releases to Basins (Ci)

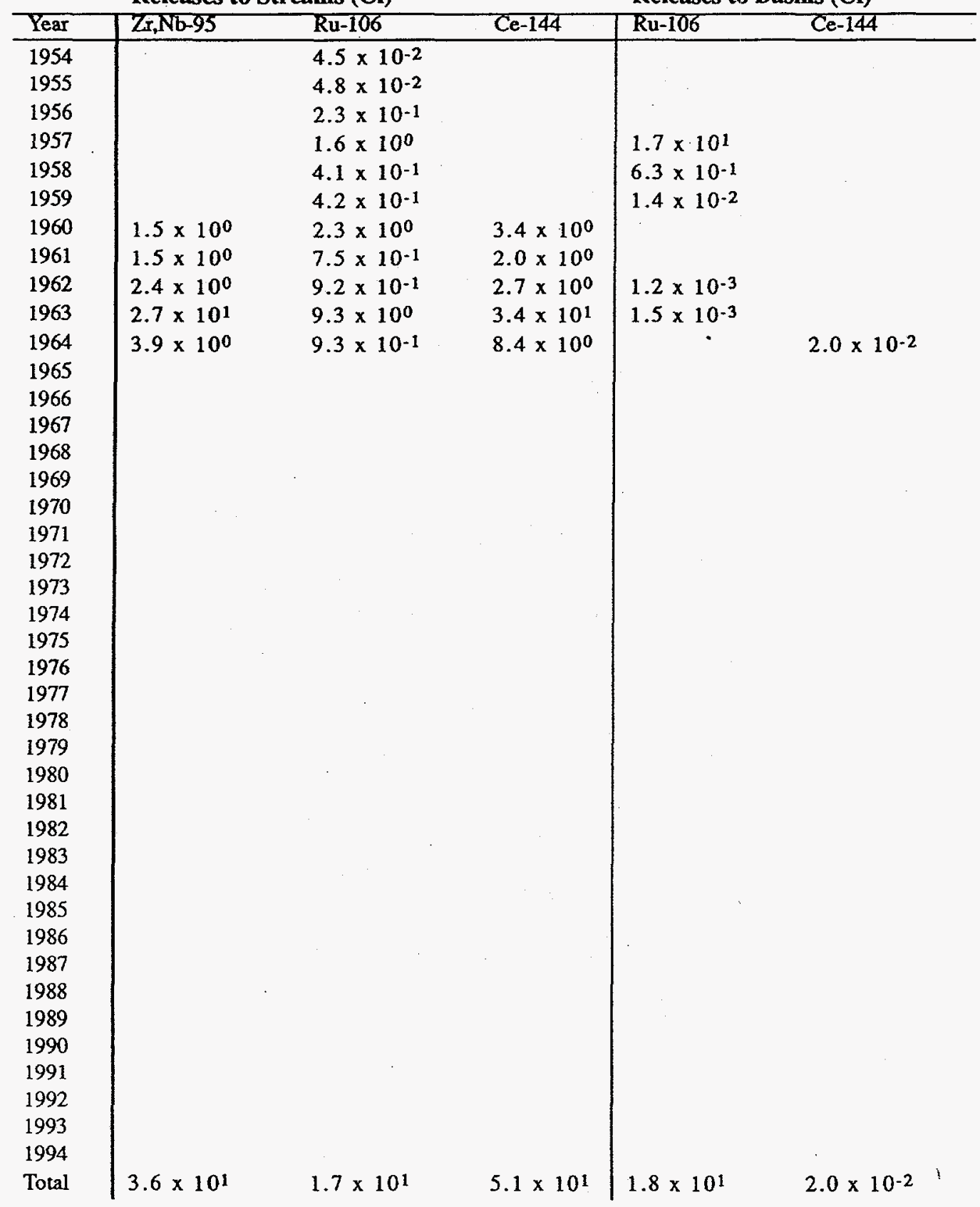


Assessment of Selected Fission Products in the Savannah River Site Environment (U)

Table 3-6. F-Area Releases

Releases to Atmosphere (Ci)

Releases to Basins (Ci)

\begin{tabular}{|c|c|c|c|c|c|c|c|c|c|c|c|c|}
\hline Year & $2,18 b-95$ & Nb-95 & Ru-103 & $\mathrm{Ru}-106$ & $\mathrm{Ce}-141$ & Ce-144 & $2 \mathrm{~s}_{1} \mathrm{Nb}-95$ & Nis-95 & $\mathrm{Ru}-103$ & Ru-106 & Ce-141 & $\operatorname{Ce}[44$ \\
\hline 1954 & & & & & & & & & & & & \\
\hline 1955 & & & & $7.3 \times 10^{0}$ & & & & & & $5.0 \times 10^{0}$ & & \\
\hline 1956 & & & & $4.0 \times 10^{0}$ & & & & & & $9.2 \times 10^{0}$ & & \\
\hline 1957 & & & & $4.4 \times 10^{-1}$ & & & & & & $2.3 \times 10^{1}$ & & \\
\hline 1958 & & & & $2.3 \times 10^{-1}$ & & & & & & $1.1 \times 10^{1}$ & & \\
\hline 1959 & & & & $8.0 \times 10^{0}$ & & & & & & $4.8 \times 10^{1}$ & & \\
\hline 1960 & $1.6 \times 10^{-1}$ & & & $8.7 \times 10^{0}$ & & $1.6 \times 10^{-1}$ & $1.5 \times 10^{2}$ & & & $1.4 \times 10^{2}$ & & $7.8 \times 10^{1}$ \\
\hline 1961 & $25 \times 10^{-1}$ & & & $6.7 \times 10^{-1}$ & & $1.7 \times 10^{-1}$ & $3.0 \times 10^{1}$ & & & $3.6 \times 10^{1}$ & & $3.3 \times 10^{1}$ \\
\hline 1962 & $1.2 \times 10^{-1}$ & & & $2.5 \times 10^{0}$ & & $5.6 \times 10^{-2}$ & $1.9 \times 10^{1}$ & & & $8.1 \times 10^{1}$ & & $9.5 \times 10^{0}$ \\
\hline 1963 & $1.0 \times 10^{-1}$ & & & $1.2 \times 10^{0}$ & & $9.6 \times 10^{-2}$ & $3.0 \times 10^{1}$ & & & $7.0 \times 10^{1}$ & & $2.3 \times 10^{1}$ \\
\hline 1964 & $1.5 \times 10^{-1}$ & & & $1.6 \times 10^{0}$ & & $1.8 \times 10^{-1}$ & $1.0 \times 10^{2}$ & & & $20 \times 10^{2}$ & & $1.9 \times 10^{1}$ \\
\hline 1965 & $1.5 \times 10^{-1}$ & & & $2.6 \times 10^{0}$ & & $1.5 \times 10^{-1}$ & $2.5 \times 10^{1}$ & & & $8.9 \times 10^{1}$ & & $2.8 \times 10^{1}$ \\
\hline 1966 & $9.5 \times 10^{-2}$ & & & $1.1 \times 10^{0}$ & & $6.6 \times 10^{-2}$ & $2.4 \times 10^{1}$ & & & $6.3 \times 10^{1}$ & & $2.4 \times 10^{0}$ \\
\hline 1967 & $1.6 \times 10^{-1}$ & & & $1.2 \times 10^{-1}$ & & $2.9 \times 10^{-2}$ & $2.0 \times 10^{1}$ & & & $4.7 \times 10^{1}$ & & $1.3 \times 100$ \\
\hline 1968 & $9.7 \times 10^{-2}$ & & & $1.4 \times 10^{-1}$ & & $3.2 \times 10^{-2}$ & $1.0 \times 10^{1}$ & & & $4.4 \times 10^{1}$ & & $2.0 \times 10^{0}$ \\
\hline 1969 & $6.0 \times 10^{-2}$ & & $1.1 \times 10^{-1}$ & $1.1 \times 10^{-1}$ & & $2.9 \times 10^{-2}$ & $1.2 \times 10^{1}$ & & & $1.4 \times 10^{1}$ & & $2.2 \times 10^{0}$ \\
\hline 1970 & $3.5 \times 10^{-2}$ & & & $3.1 \times 10^{-1}$ & & $4.1 \times 10^{-2}$ & $1.9 \times 10^{1}$ & & & $3.9 \times 10^{1}$ & & $3.5 \times 10^{0}$ \\
\hline 1971 & $24 \times 10^{-2}$ & $23 \times 10^{-1}$ & $1.3 \times 10^{-2}$ & $1.1 \times 10^{-1}$ & $1.8 \times 10^{-3}$ & $1.7 \times 10^{-2}$ & $3.6 \times 10^{0}$ & $3.3 \times 10^{00}$ & $1.9 \times 10^{0}$ & $1.2 \times 10^{1}$ & $20 \times 10^{-2}$ & $1.6 \times 10^{0}$ \\
\hline 1972 & $1.3 \times 10^{-2}$ & $3.3 \times 10^{-2}$ & $6.8 \times 10^{-3}$ & $2.7 \times 10^{-2}$ & $4.0 \times 10^{-4}$ & $4.2 \times 10^{-3}$ & $4.0 \times 10^{0}$ & $3.7 \times 10^{00}$ & $20 \times 10^{0}$ & $1.6 \times 10^{1}$ & $4.0 \times 10^{-2}$ & $3.5 \times 10^{-1}$ \\
\hline 1973 & $1.7 \times 10^{-2}$ & $4.0 \times 10^{-2}$ & $3.6 \times 10^{-3}$ & $3.3 \times 10^{-2}$ & $4.5 \times 10^{-4}$ & $8.9 \times 10^{-3}$ & $9.8 \times 10^{0}$ & $1.0 \times 10^{1}$ & $2.2 \times 10^{0}$ & $28 \times 10^{1}$ & & $3.1 \times 10^{-1}$ \\
\hline 1974 & $1.8 \times 10^{-2}$ & $1.1 \times 10^{-1}$ & $3.4 \times 10^{-3}$ & $2.7 \times 10^{-2}$ & $9.3 \times 10^{-4}$ & $1.8 \times 10^{-2}$ & $3.4 \times 100$ & $3.6 \times 10^{0}$ & $1.4 \times 100$ & $1.3 \times 10^{1}$ & & $1.9 \times 10^{-1}$ \\
\hline 1975 & $3.7 \times 10^{-3}$ & $1.4 \times 10^{-2}$ & $7.1 \times 10^{-4}$ & $1.0 \times 10^{-2}$ & $1.9 \times 10^{-4}$ & $8.4 \times 10^{-3}$ & $7.3 \times 10^{-1}$ & $4.3 \times 10^{-1}$ & $8.2 \times 10^{-2}$ & $4.0 \times 10^{0}$ & $1.0 \times 10^{-3}$ & $1.9 \times 10^{-1}$ \\
\hline 1976 & $7.7 \times 10^{-3}$ & $2.2 \times 10^{-2}$ & $1.3 \times 10^{-3}$ & $1.3 \times 10^{-2}$ & $1.7 \times 10^{-4}$ & $6.6 \times 10^{-3}$ & $5.2 \times 10^{00}$ & $3.0 \times 100$ & $1.0 \times 100$ & $7.4 \times 10^{0}$ & & $9.0 \times 10^{-3}$ \\
\hline 1977 & $7.6 \times 10^{-3}$ & $3.3 \times 10^{-2}$ & $1.5 \times 10^{-3}$ & $1.0 \times 10^{-2}$ & $2.1 \times 10^{-4}$ & $4.8 \times 10^{-3}$ & $2.0 \times 10^{0}$ & $1.2 \times 10^{0}$ & $1.2 \times 10^{0}$ & $6.0 \times 10^{0}$ & & $3.7 \times 10^{-2}$ \\
\hline 1978 & $5.4 \times 10^{-3}$ & $1.6 \times 10^{-2}$ & $8.0 \times 10^{-1}$ & $3.2 \times 10^{1}$ & $8.4 \times 10^{-5}$ & $1.0 \times 10^{-2}$ & $1.6 \times 10^{0}$ & $8.8 \times 10^{-1}$ & $6.6 \times 10^{-1}$ & $1.3 \times 10^{1}$ & $1.8 \times 10^{-4}$ & $4.8 \times 10^{-2}$ \\
\hline 1979 & $1.2 \times 10^{-2}$ & $2.5 \times 10^{-2}$ & $1.2 \times 10^{-3}$ & $3.2 \times 10^{-2}$ & $1.6 \times 10^{-4}$ & $1.5 \times 10^{-2}$ & $1.8 \times 10^{0}$ & $1.2 \times 10^{00}$ & $7.3 \times 10^{-1}$ & $1.1 \times 10^{1}$ & $20 \times 10^{-3}$ & $2.3 \times 10^{-1}$ \\
\hline 1980 & $1.3 \times 10^{-2}$ & $1.7 \times 10^{-2}$ & $1.3 \times 10^{-3}$ & $2.7 \times 10^{-2}$ & $1.1 \times 10^{-4}$ & $1.1 \times 10^{-2}$ & $3.1 \times 10^{0}$ & $1.9 \times 10^{0}$ & $1.2 \times 10^{0}$ & $1.8 \times 10^{1}$ & & $1.5 \times 10^{-2}$ \\
\hline 1981 & $1.3 \times 10^{-2}$ & $6.1 \times 10^{-2}$ & $2.8 \times 10^{-3}$ & $2.3 \times 10^{-2}$ & $2.6 \times 10^{-4}$ & $1.3 \times 10^{-2}$ & $5.5 \times 10^{0}$ & $4.0 \times 100$ & $20 \times 10^{0}$ & $1.8 \times 10^{1}$ & & $6.7 \times 10^{-1}$ \\
\hline 1982 & $1.2 \times 10^{-2}$ & $1.4 \times 10^{-2}$ & $9.5 \times 10^{-3}$ & $2.4 \times 10^{-2}$ & $3.8 \times 10^{-4}$ & $4.7 \times 10^{-3}$ & $6.2 \times 10^{0}$ & $3.9 \times 10^{0}$ & $21 \times 10^{0}$ & $4.7 \times 100$ & $4.1 \times 10^{-3}$ & $6.8 \times 10^{-2}$ \\
\hline 1983 & $9.0 \times 10^{-3}$ & $1.5 \times 10^{-2}$ & $2.2 \times 10^{-3}$ & $5.9 \times 10^{-3}$ & $4.3 \times 10^{-4}$ & $6.3 \times 10^{-3}$ & $3.6 \times 10^{0}$ & $3.0 \times 100$ & $3.1 \times 10^{-1}$ & $7.8 \times 10^{-1}$ & & $1.3 \times 10^{-2}$ \\
\hline 1984 & $7.2 \times 10^{-3}$ & $1.4 \times 10^{-2}$ & $7.1 \times 10^{-3}$ & $1.3 \times 10^{-2}$ & $8.3 \times 10^{-4}$ & $1.1 \times 10^{-2}$ & $6.9 \times 100$ & $4.7 \times 10^{0}$ & $3.2 \times 10^{-1}$ & $6.6 \times 10^{-1}$ & $3.0 \times 10^{-3}$ & $6.4 \times 10^{-2}$ \\
\hline 1985 & $1.3 \times 10^{-2}$ & $3.3 \times 10^{-2}$ & $8.9 \times 10^{-3}$ & $1.7 \times 10^{-2}$ & $3.6 \times 10^{-3}$ & $4.8 \times 10^{-2}$ & $1.0 \times 10^{1}$ & $8.4 \times 100$ & $7.6 \times 10^{-1}$ & $22 \times 10^{0}$ & & $1.7 \times 10^{-1}$ \\
\hline 1986 & $2.2 \times 10^{-3}$ & $6.9 \times 10^{-3}$ & $7.5 \times 10^{-4}$ & $7.6 \times 10^{-3}$ & $1.5 \times 10^{-5}$ & $2.4 \times 10^{-3}$ & $8.3 \times 10^{-1}$ & $9.3 \times 10^{-1}$ & $4.0 \times 10^{-1}$ & $1.9 \times 10^{0}$ & & $3.5 \times 10^{-1}$ \\
\hline 1987 & $1.1 \times 10^{-3}$ & $2.1 \times 10^{-3}$ & $6.9 \times 10^{-4}$ & $3.4 \times 10^{-2}$ & $4.0 \times 10^{-6}$ & $2.8 \times 10^{-3}$ & $1.3 \times 10^{-1}$ & $1.8 \times 10^{-1}$ & $2.2 \times 10^{-3}$ & $4.2 \times 10^{-1}$ & $4.1 \times 10^{-4}$ & $1.3 \times 10^{-1}$ \\
\hline 1988 & $3.5 \times 10^{-4}$ & $1.4 \times 10^{-3}$ & $4.7 \times 10^{-5}$ & $1.1 \times 10^{-2}$ & $1.6 \times 10^{-5}$ & $2.8 \times 10^{-3}$ & $1.8 \times 10^{-2}$ & $2.3 \times 10^{-2}$ & & $1.3 \times 10^{-1}$ & & $5.6 * 10^{-2}$ \\
\hline 1989 & $5.8 \times 10^{-5}$ & $1.3 \times 10^{-4}$ & $7.0 \times 10^{-6}$ & $2.8 \times 10^{-3}$ & $1.0 \times 10^{-6}$ & $6.6 \times 10^{-4}$ & & & & & & \\
\hline 1990 & & & & $6.0 \times 10^{-4}$ & $3.9 \times 10^{-7}$ & $2.5 \times 10^{-4}$ & & & & & & \\
\hline 1991 & & & & $2.0 \times 10^{-7}$ & & $8.2 \times 10^{-8}$ & & & & & & \\
\hline 1992 & & & & & & & & & & & & \\
\hline $\begin{array}{l}1993 \\
1994\end{array}$ & & & & $1.2 \times 10^{-8}$ & & & & & & & & \\
\hline Total & $1.6 \times 10^{0}$ & $6.9 \times 10^{-1}$ & $9.7 \times 10^{-1}$ & $7.1 \times 10^{1}$ & $1.0 \times 10^{-2}$ & $1.2 \times 10^{0}$ & $5.1 \times 10^{2}$ & $5.4 \times 10^{1}$ & $1.8 \times 10^{1}$ & $1.1 \times 10^{3}$ & $7.1 \times 10^{-2}$ & $2.1 \times 10^{2}$ \\
\hline
\end{tabular}


Chapter 3. Releases and Stored Inventories of Selected Fission Products at SRS

Table 3-7. H-Area Releases

Releases to Atmosphere (Ci)

Releases to Basins (Ci)

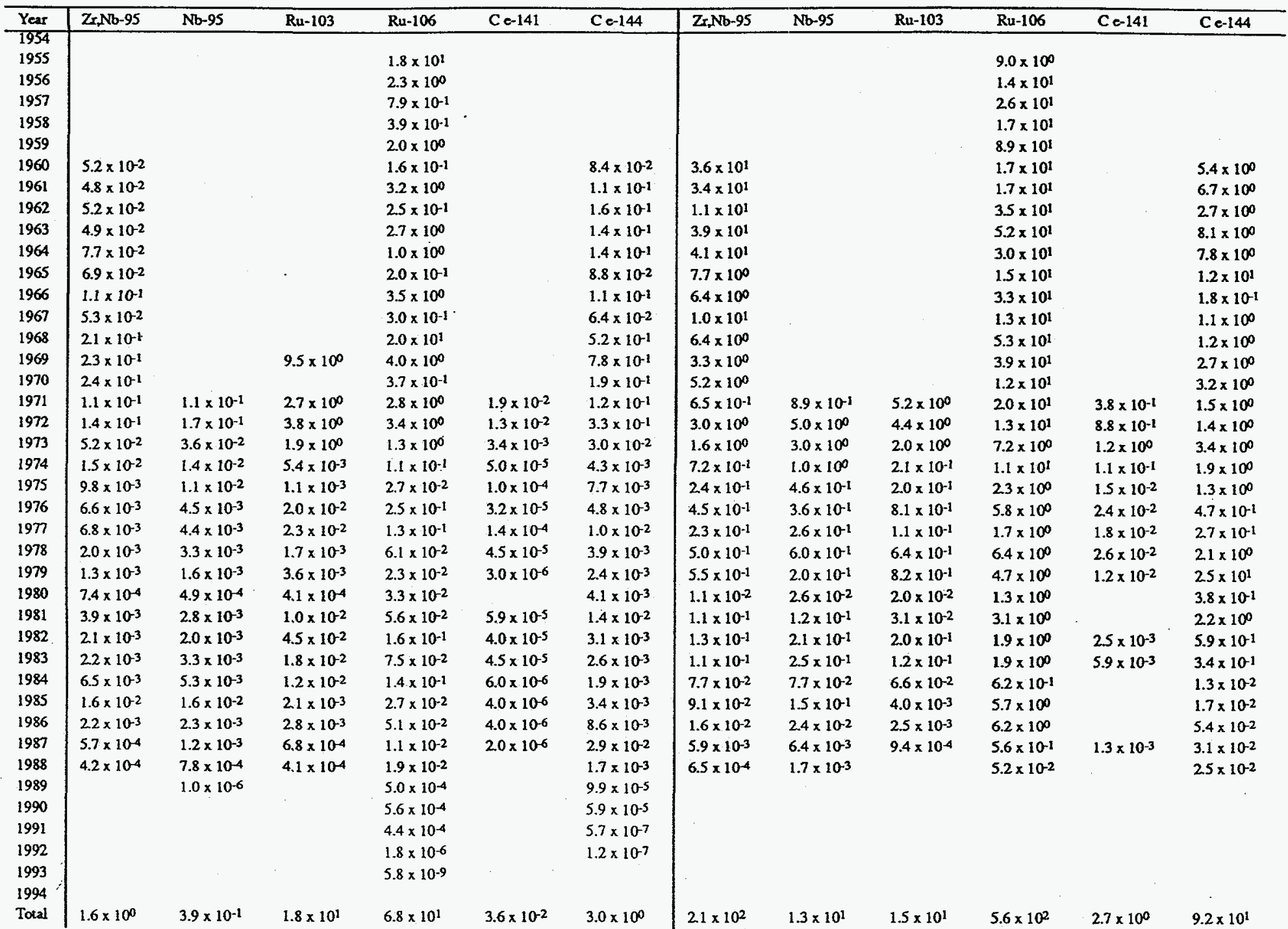


Assessment of Selected Fission Products in the Savannah River Site Environment (U)

Table 3-8. D-Area Releases

Releases to Streams (Cii)

\begin{tabular}{|c|c|c|c|}
\hline Year & $\mathrm{Z}, \mathrm{Nb}-95$ & Ru-106 & Ce-144 \\
\hline 1954 & & & \\
\hline 1955 & & & \\
\hline 1956 & & & \\
\hline 1957 & & & \\
\hline 1958 & & & \\
\hline 1959 & & & \\
\hline 1960 & & & \\
\hline 1961 & & & \\
\hline 1962 & & & \\
\hline 1963 & & & \\
\hline 1964 & & & \\
\hline 1965 & & & \\
\hline 1966 & & & \\
\hline 1967 & $3.8 \times 10^{0}$ & $2.9 \times 10^{-1}$ & $1.7 \times 10^{-1}$ \\
\hline 1968 & & $2.0 \times 10^{-2}$ & \\
\hline 1969 & & $2.0 \times 10^{-2}$ & \\
\hline 1970 & $8.0 \times 10^{-3}$ & $1.0 \times 10^{-3}$ & $6.0 \times 10^{-3}$ \\
\hline 1971 & $9.1 \times 10^{-2}$ & $2.4 \times 10^{-2}$ & $2.8 \times 10^{-2}$ \\
\hline 1972 & $5.9 \times 10^{-2}$ & $3.9 \times 10^{-2}$ & $3.2 \times 10^{-2}$ \\
\hline 1973 & $6.8 \times 10^{-2}$ & $1.8 \times 10^{-2}$ & $3.1 \times 10^{-2}$ \\
\hline 1974 & & & \\
\hline 1975 & & & \\
\hline 1976 & & & \\
\hline 1977 & & & \\
\hline 1978 & & & \\
\hline 1979 & & & \\
\hline 1980 & & & \\
\hline 1981 & & & \\
\hline 1982 & & & \\
\hline 1983 & & & \\
\hline $\begin{array}{l}1984 \\
1985\end{array}$ & & & \\
\hline 1986 & & & \\
\hline 1987 & & & \\
\hline 1988 & & & \\
\hline 1989 & & & \\
\hline 1990 & & & \\
\hline $\begin{array}{l}1991 \\
1992\end{array}$ & & & \\
\hline $\begin{array}{l}1992 \\
1993\end{array}$ & & & \\
\hline 1994 & & & \\
\hline Total & $4.0 \times 10^{0}$ & $4.1 \times 10^{-1}$ & $2.7 \times 10^{-1}$ \\
\hline
\end{tabular}




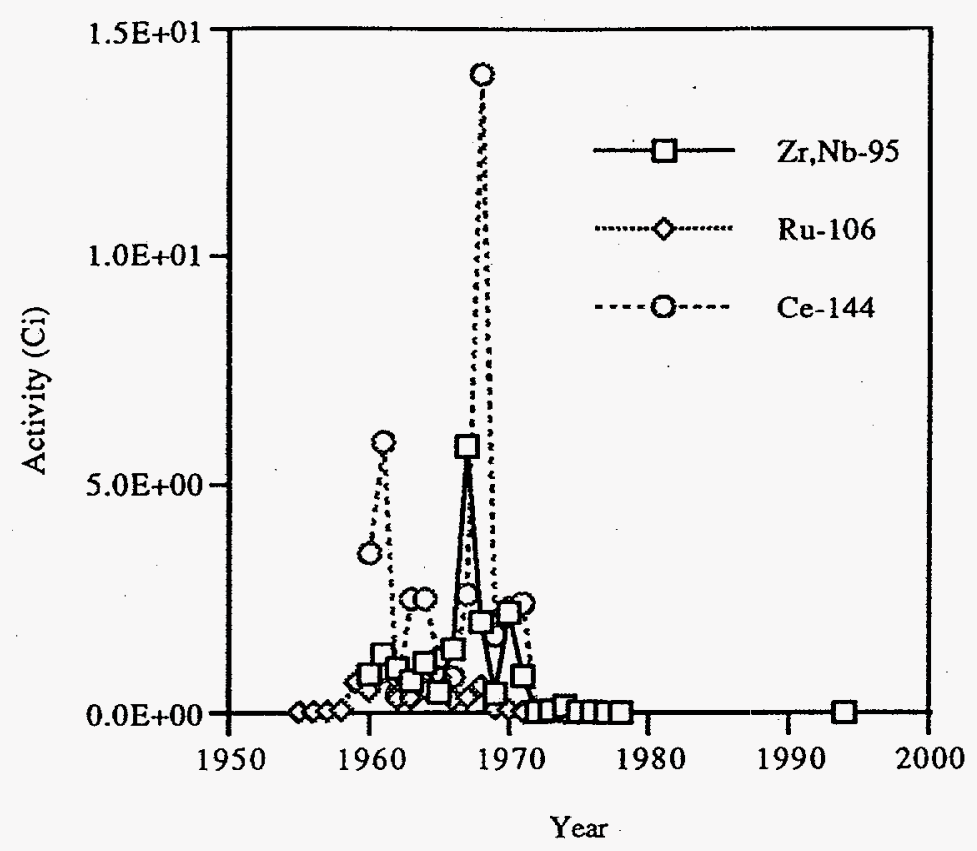

Figure 3.2. Releases to Streams, C Area

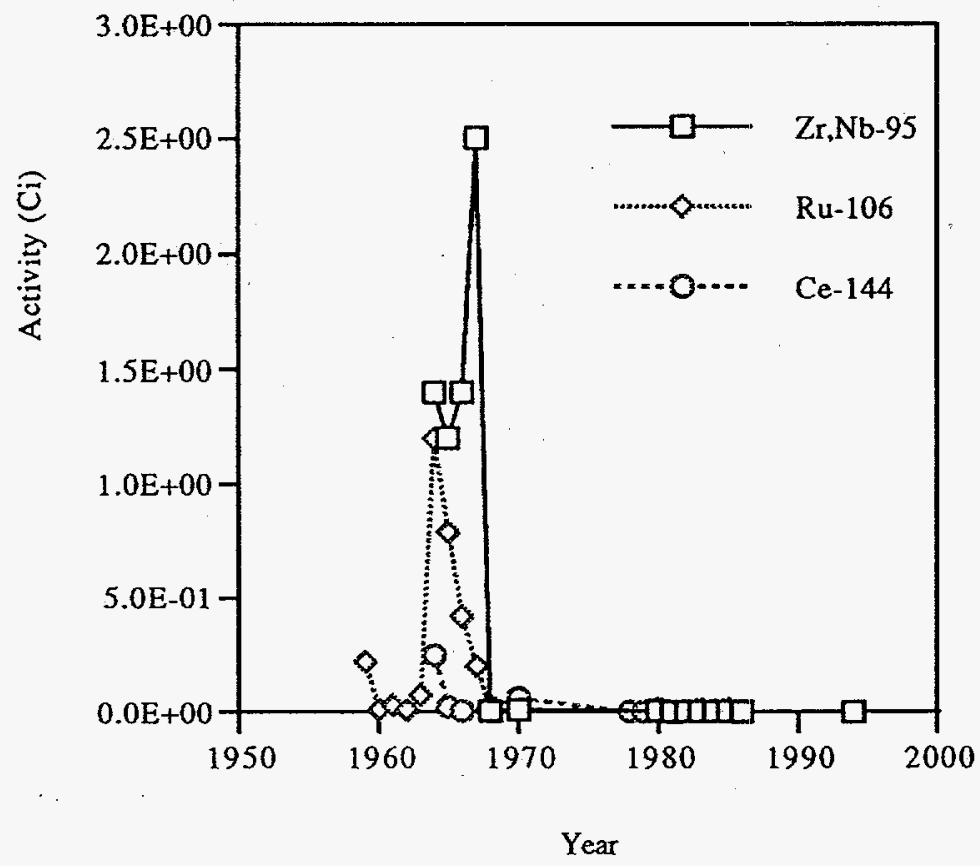

Figure 3.3. Releases to Basins, C Area 


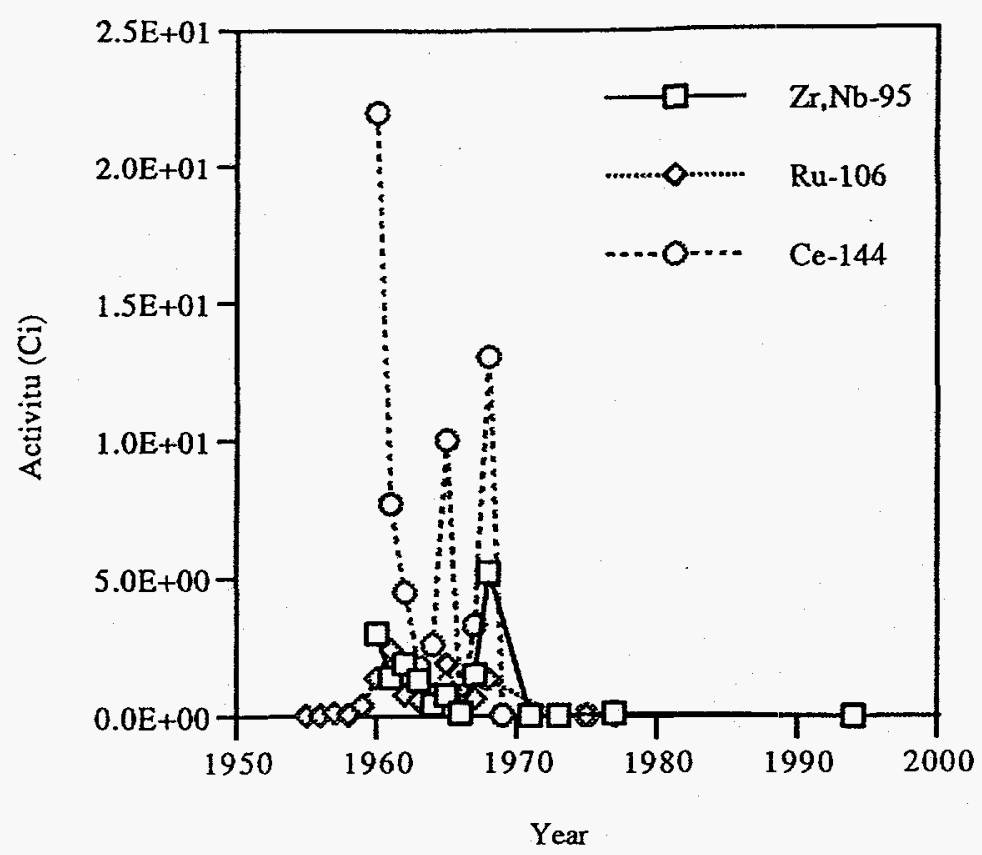

Figure 3.4. Releases to Streams, K Area

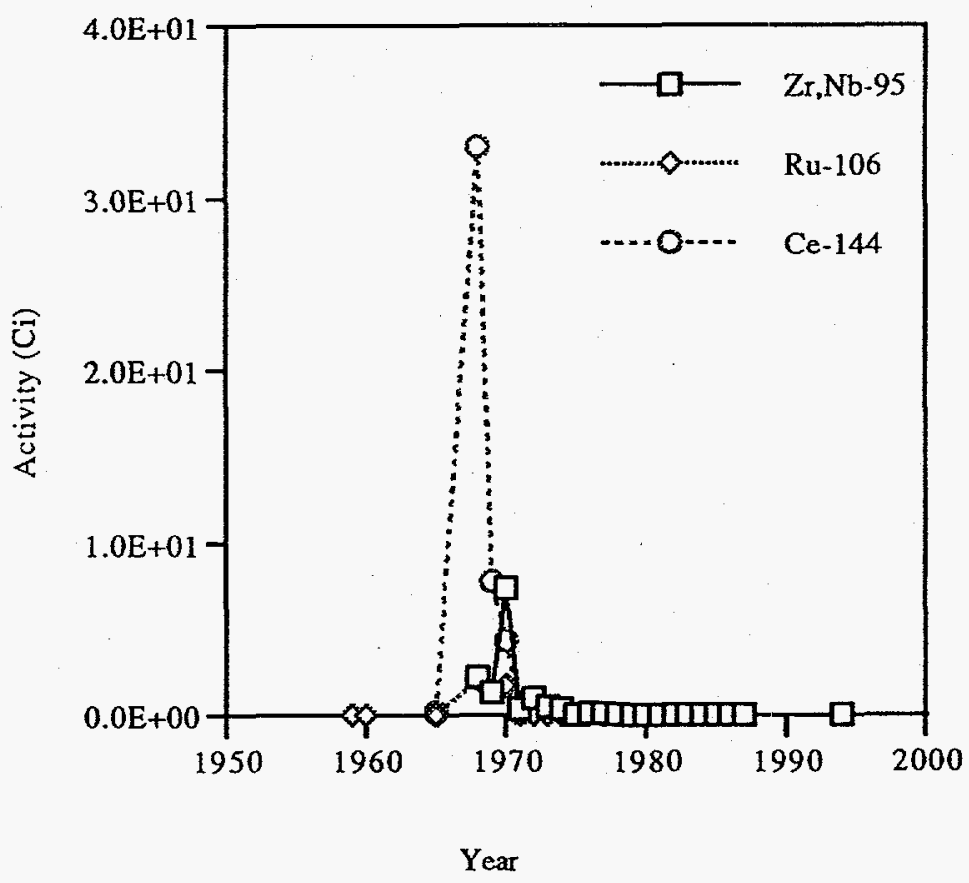

Figure 3.5. Releases to Basins, K Area 


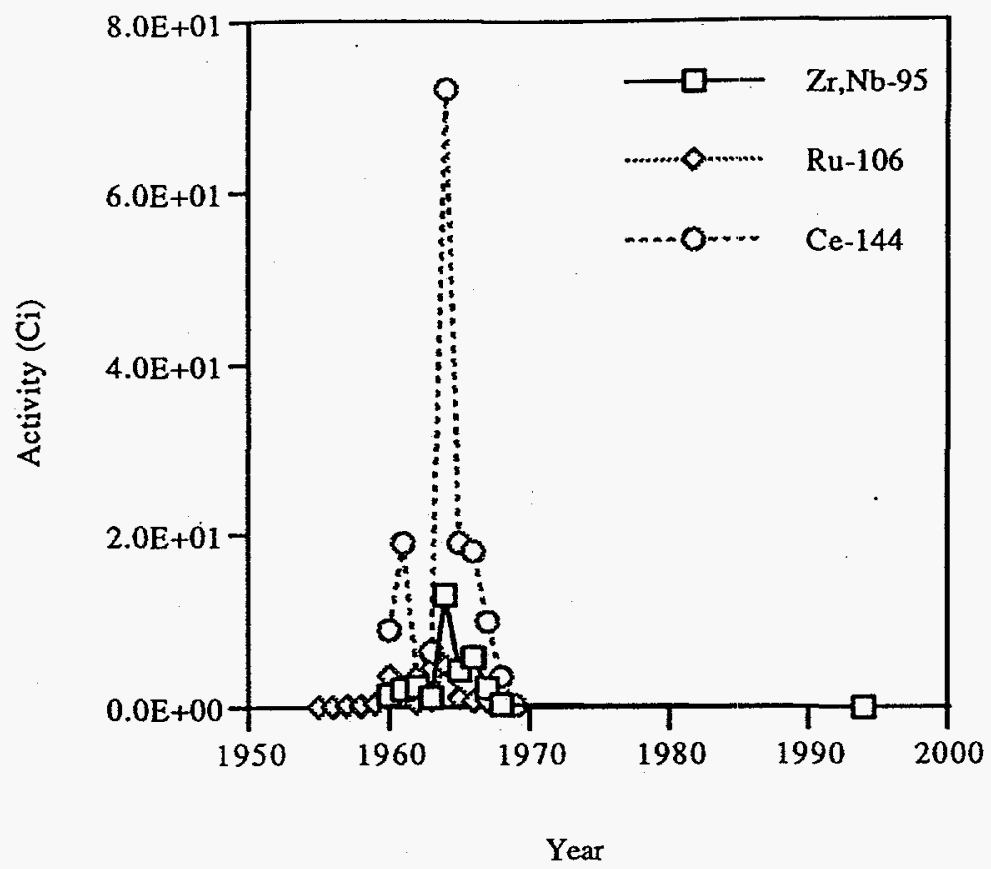

Figure 3.6. Releases to Streams, L Area

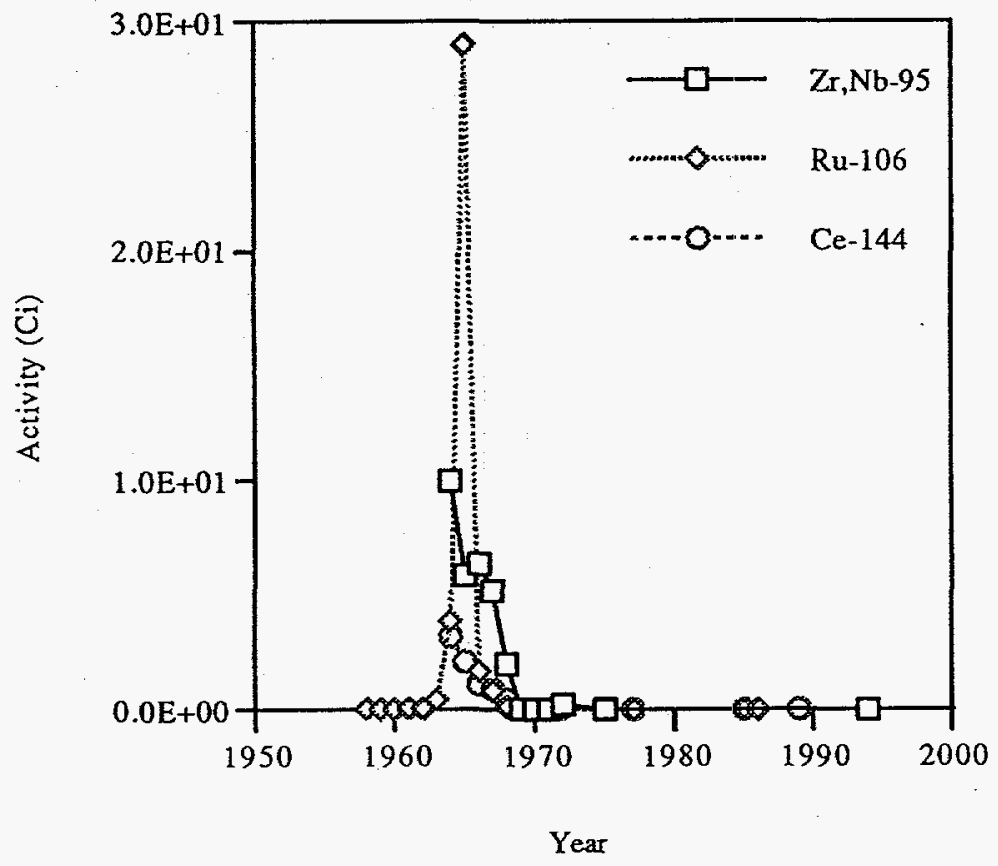

Figure 3.7. Releases to Basins, L Area 


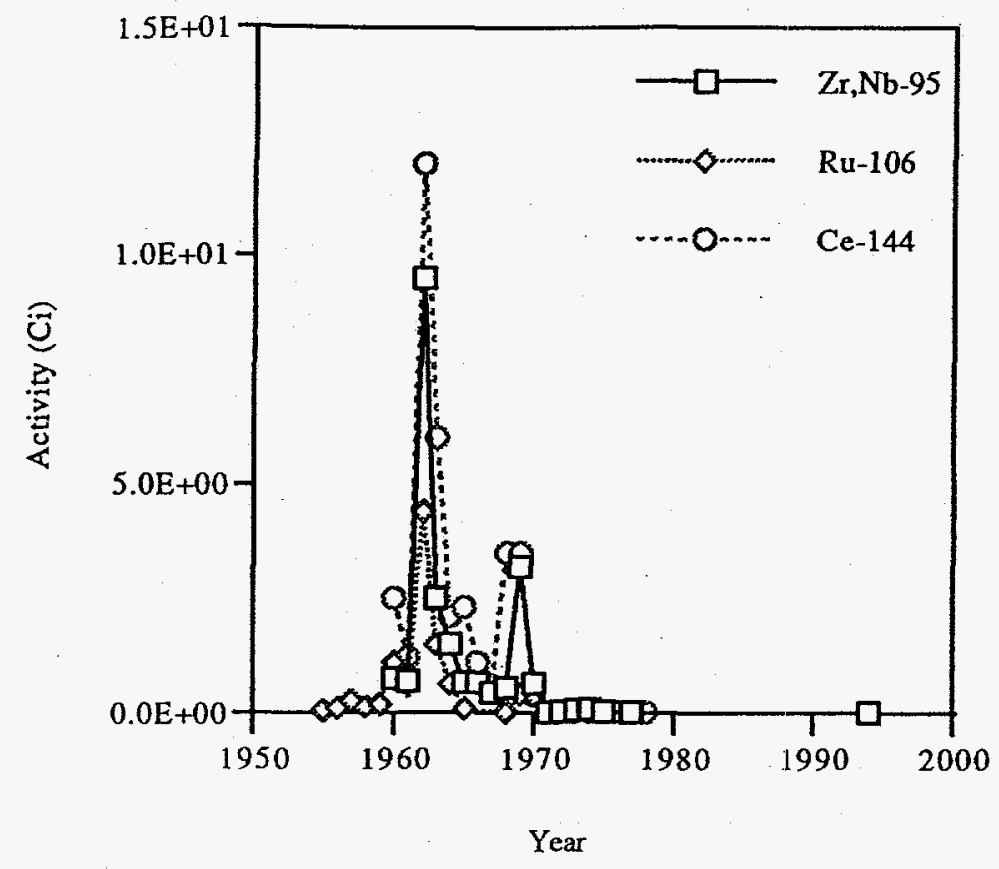

Figure 3.8. Releases to Streams, P Area

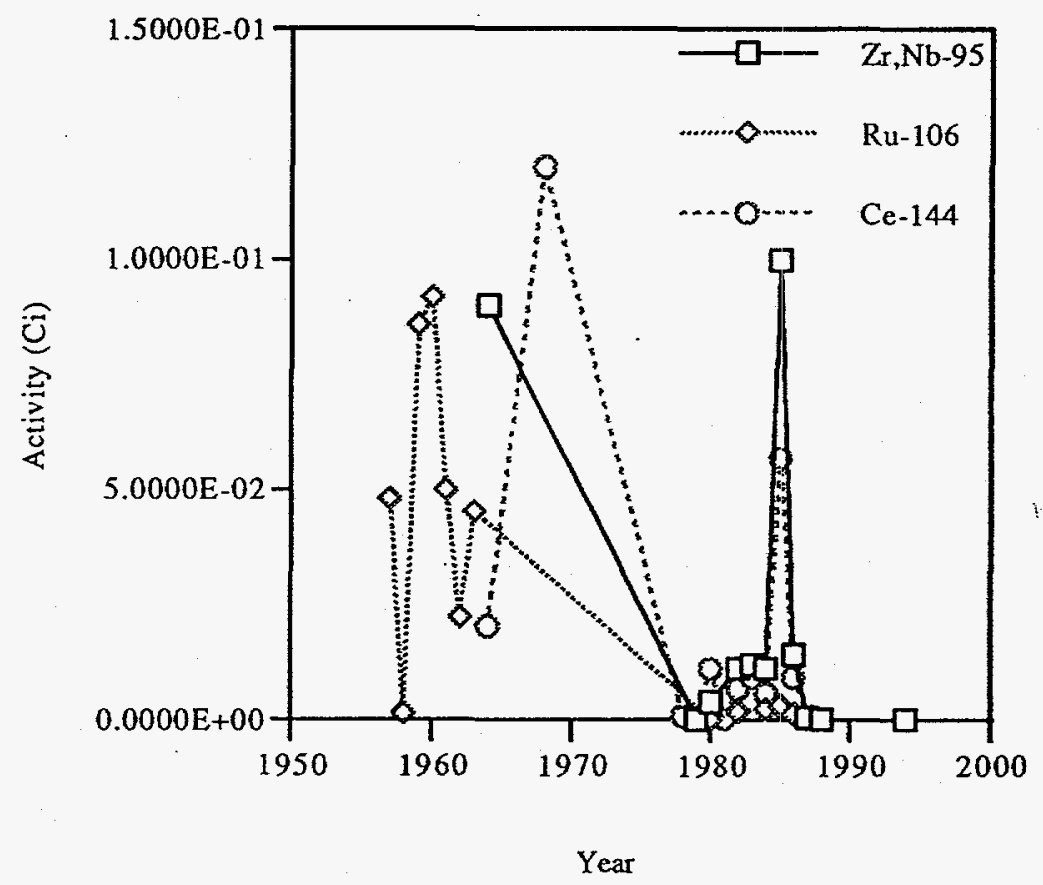

Figure 3.9. Releases to Basins, $P$ Area 


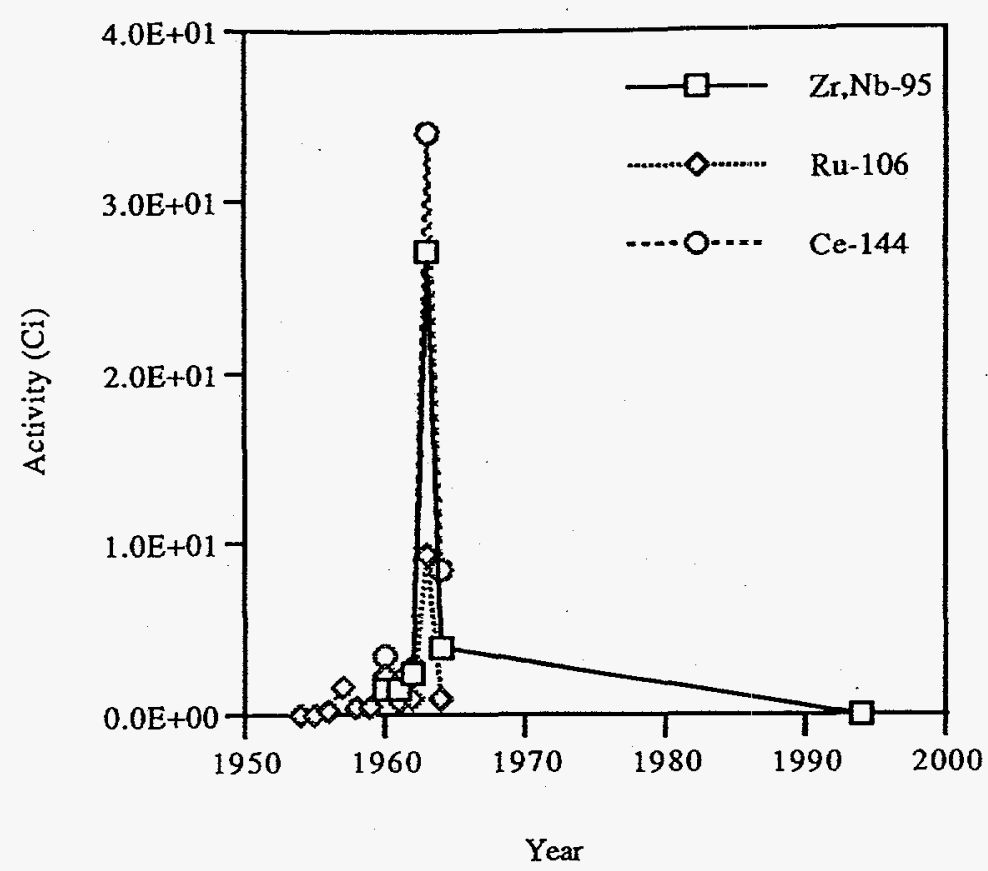

Figure 3.10. Releases to Streams, R Area

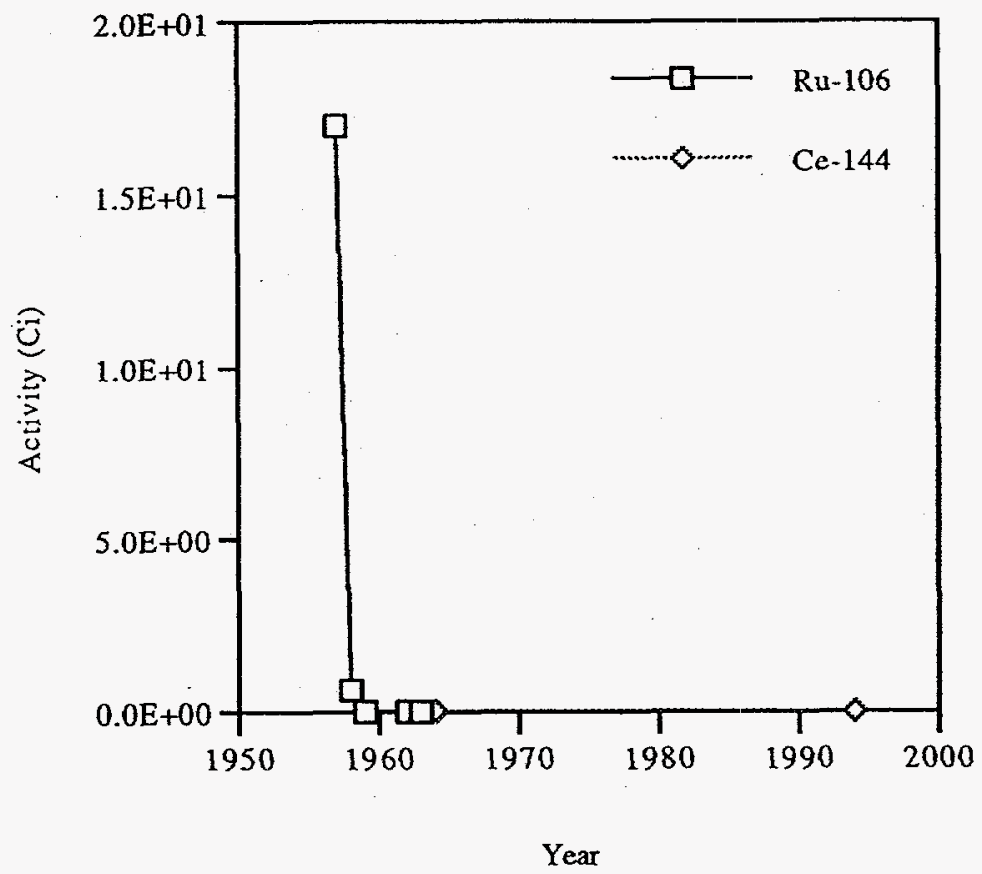

Figure 3.11. Releases to Basins, R Area 


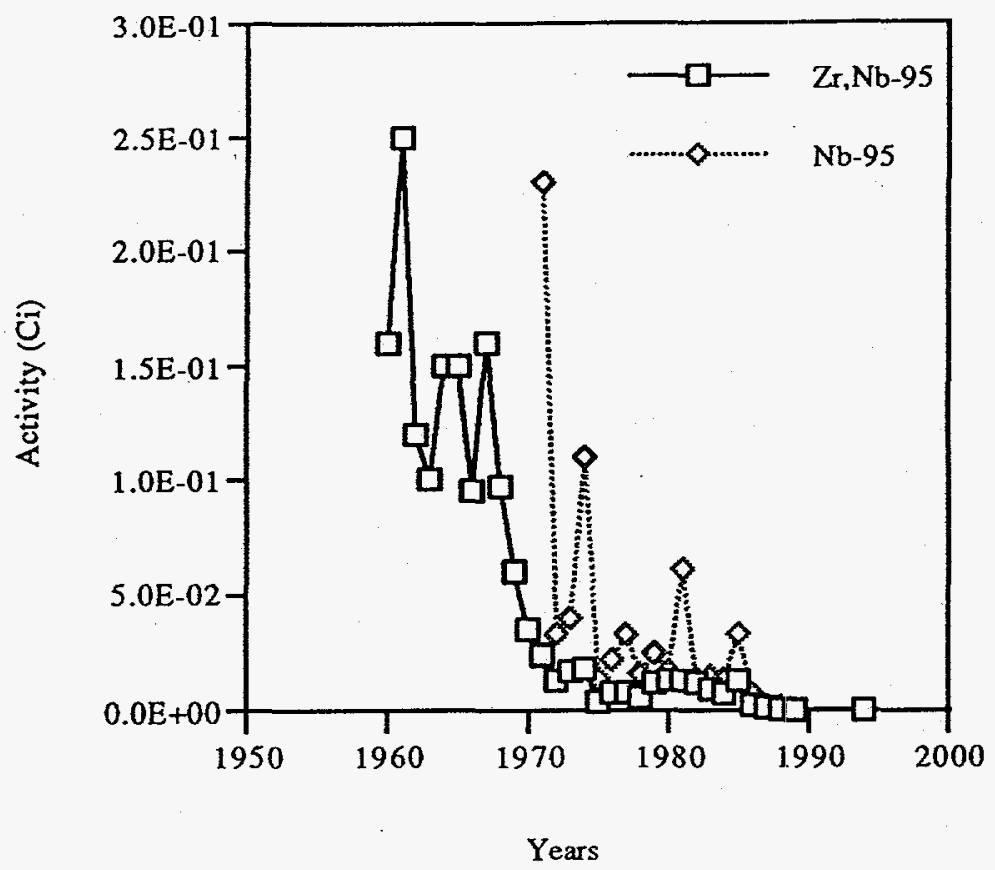

Figure 3.12. Releases to Atmosphere of $\mathrm{Zr}-\mathrm{Nb}, \mathrm{F}$ Area

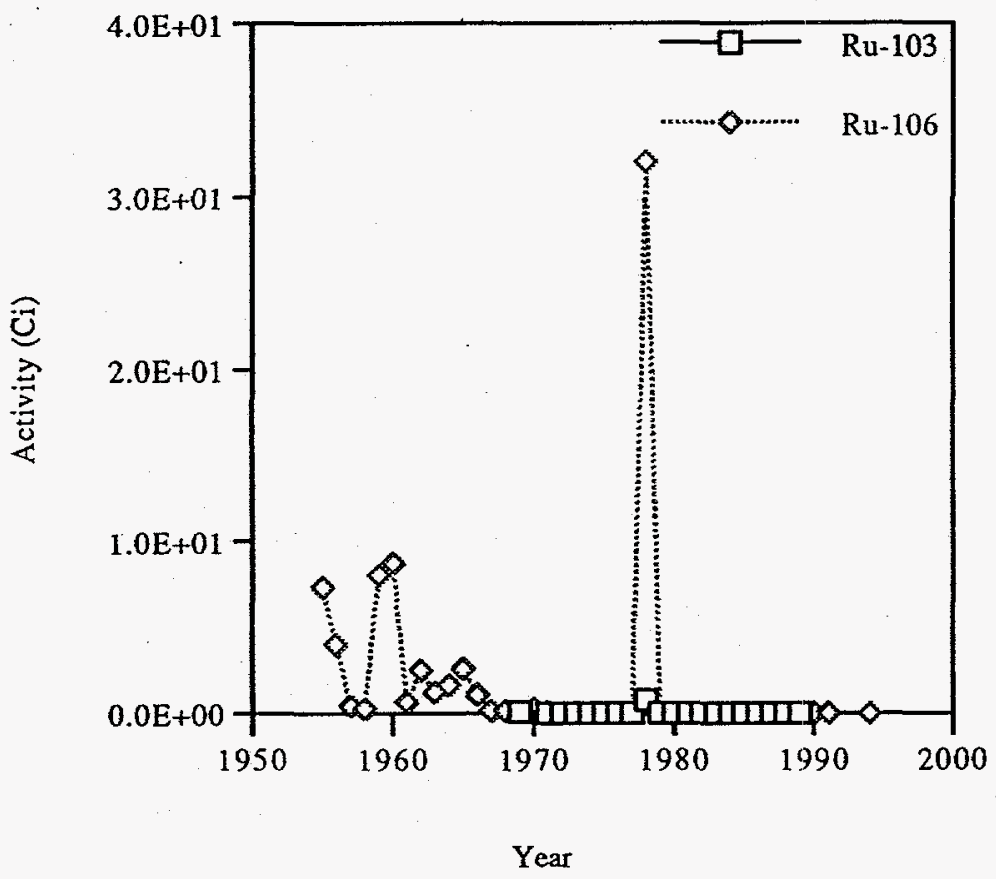

Figure 3.13. Releases to Atmosphere of Ru, F Area 


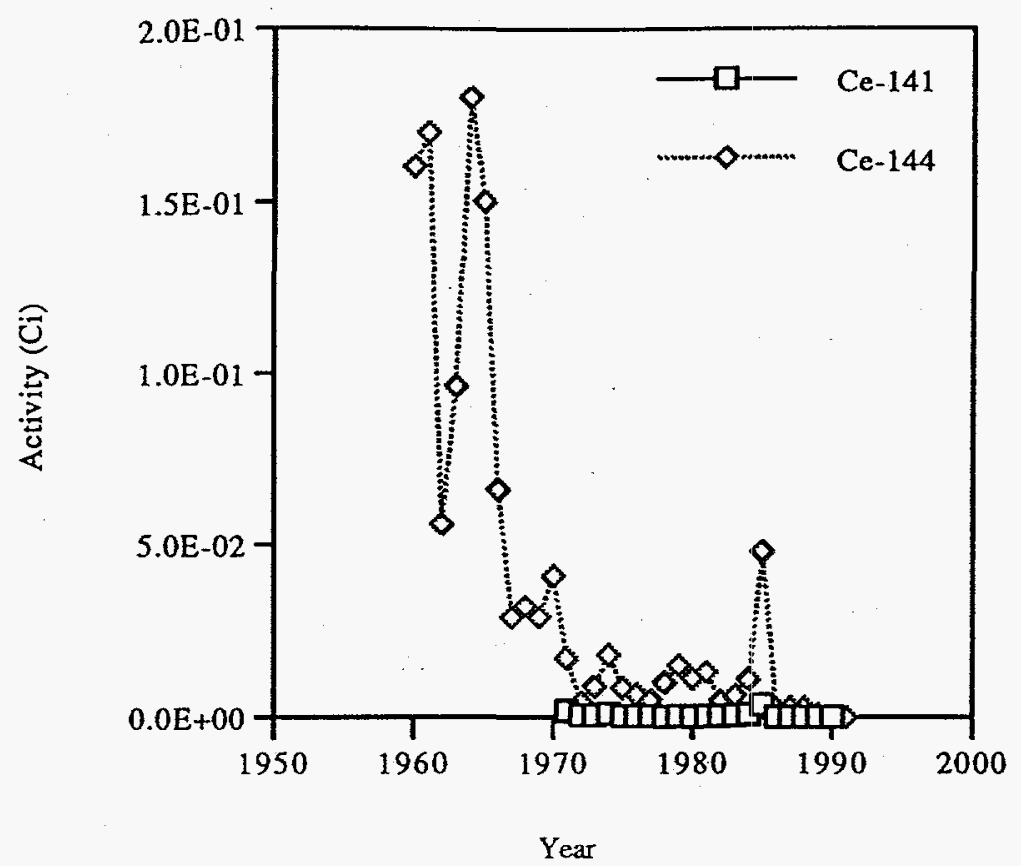

Figure 3.14. Releases to Atmosphere of Ce, F Area

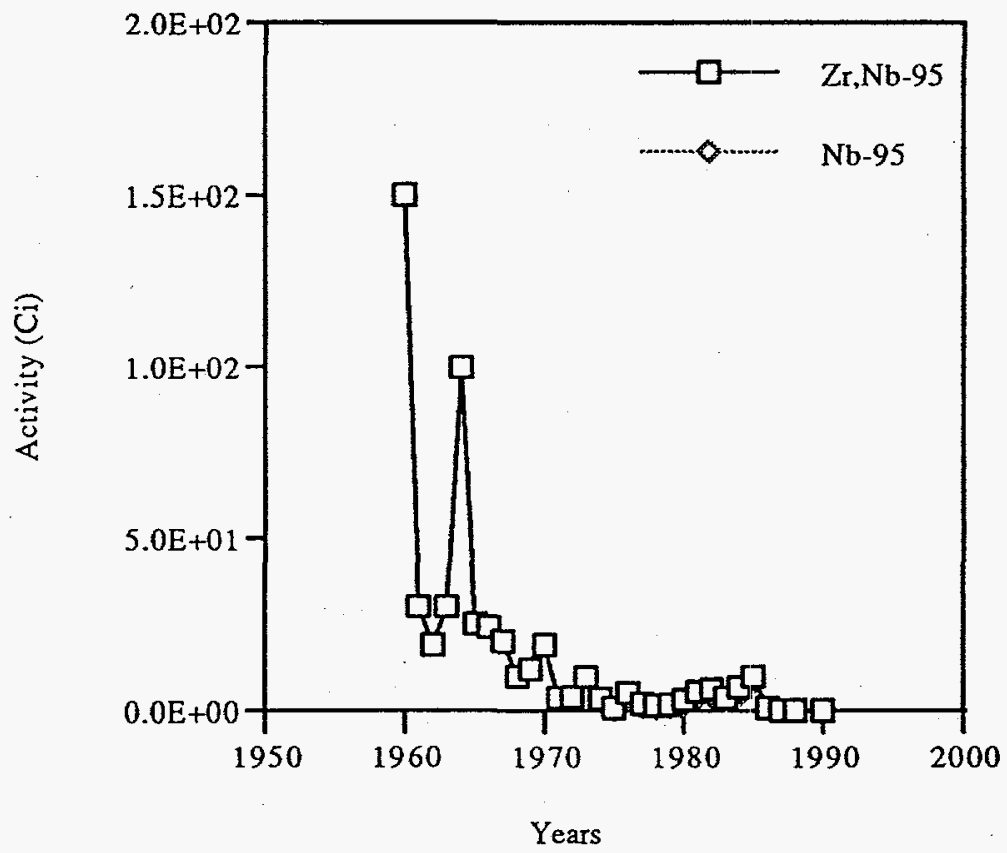

Figure 3.15. Releases to Basins of $\mathrm{Zr}-\mathrm{Nb}, \mathrm{F}$ Area 


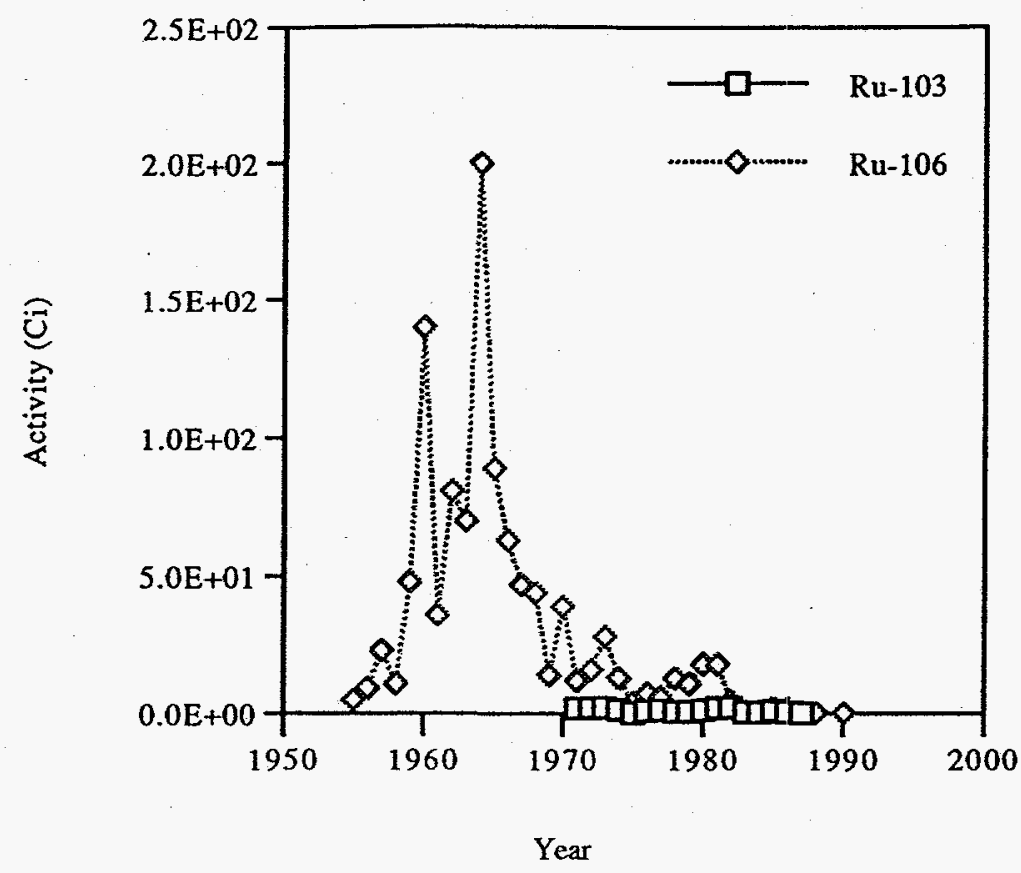

Figure 3.16. Releases to Basins of Ru, F Area

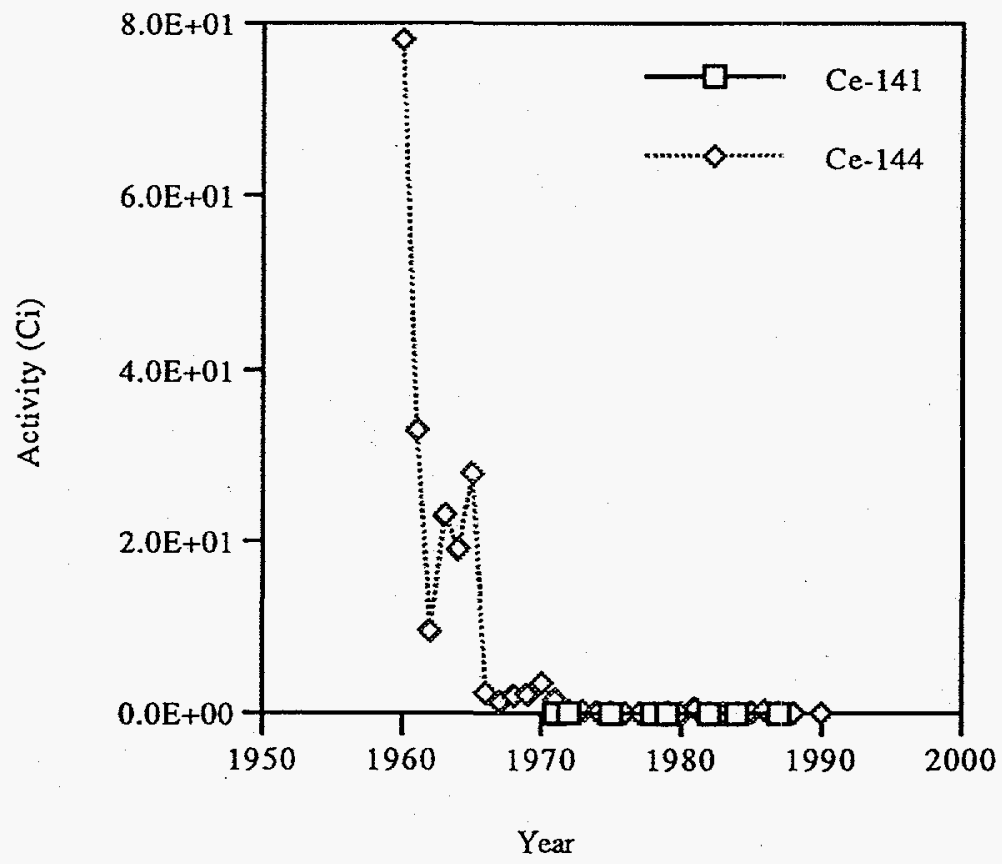

Figure 3.17. Releases to Basins of $\mathrm{Ce}, \mathrm{F}$ Area 


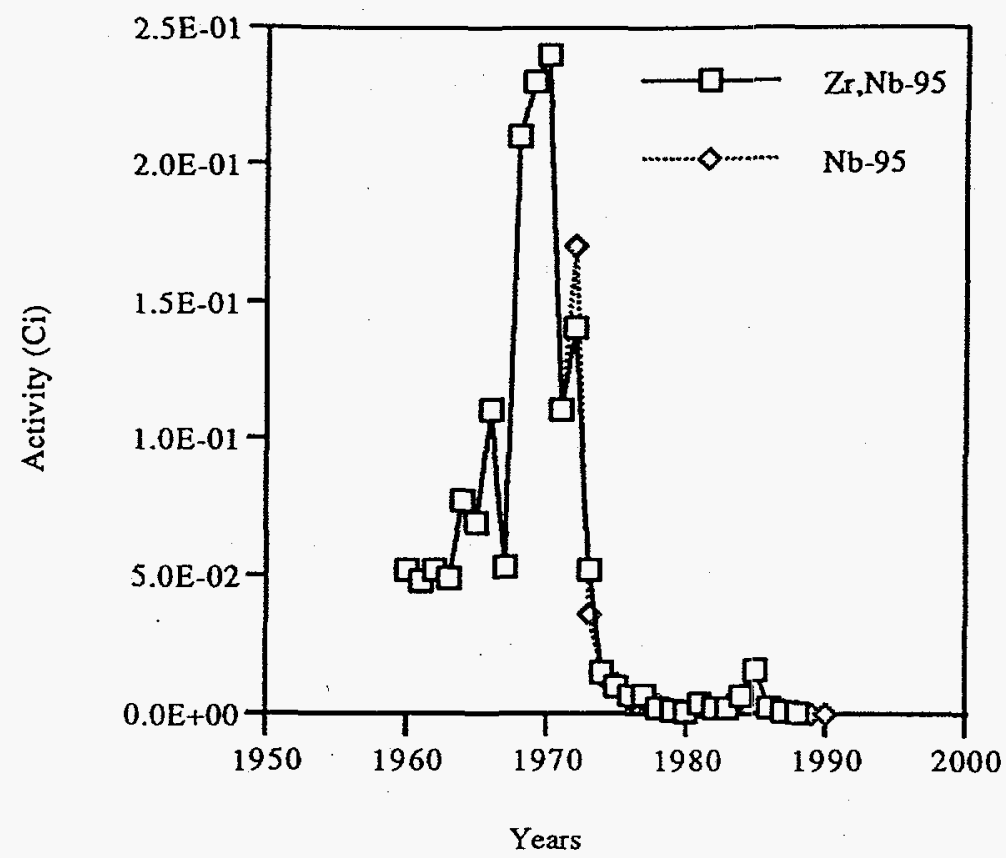

Figure 3.18. Releases to Atmosphere of $\mathrm{Zr}-\mathrm{Nb}, \mathrm{H}$ Area

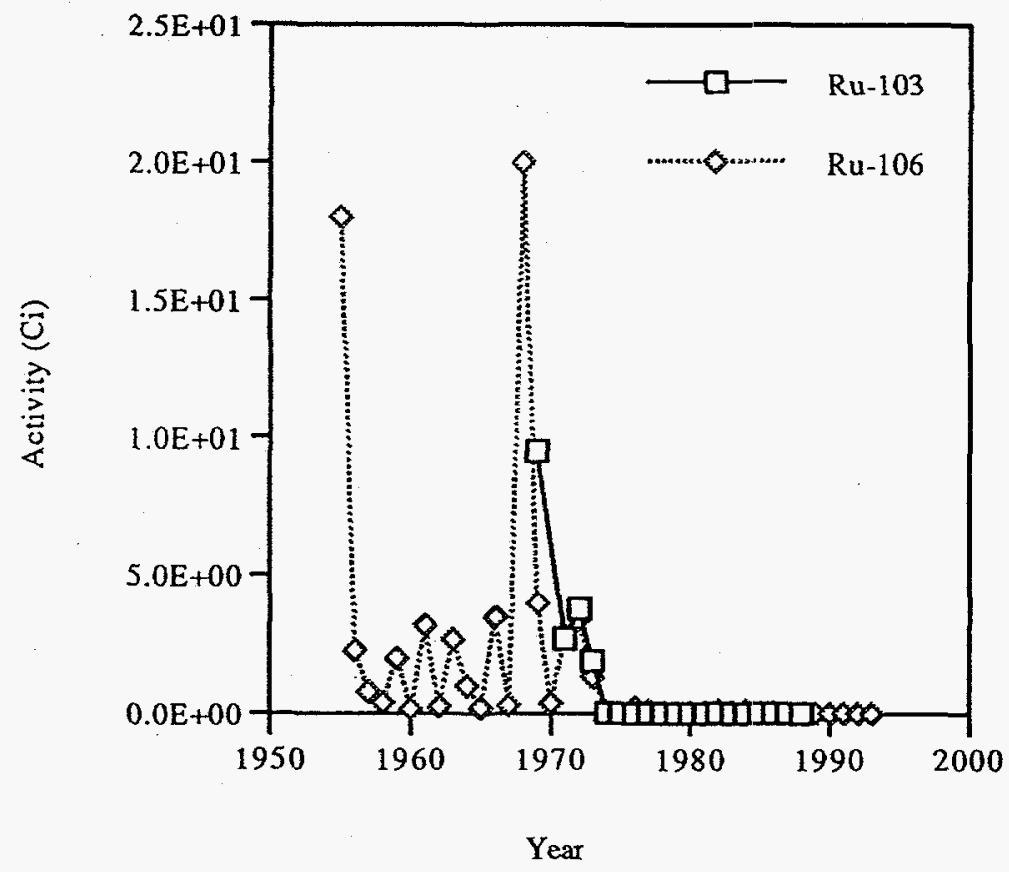

Figure 3.19. Releases to Atmosphere of Ru, $\mathrm{H}$ Area 


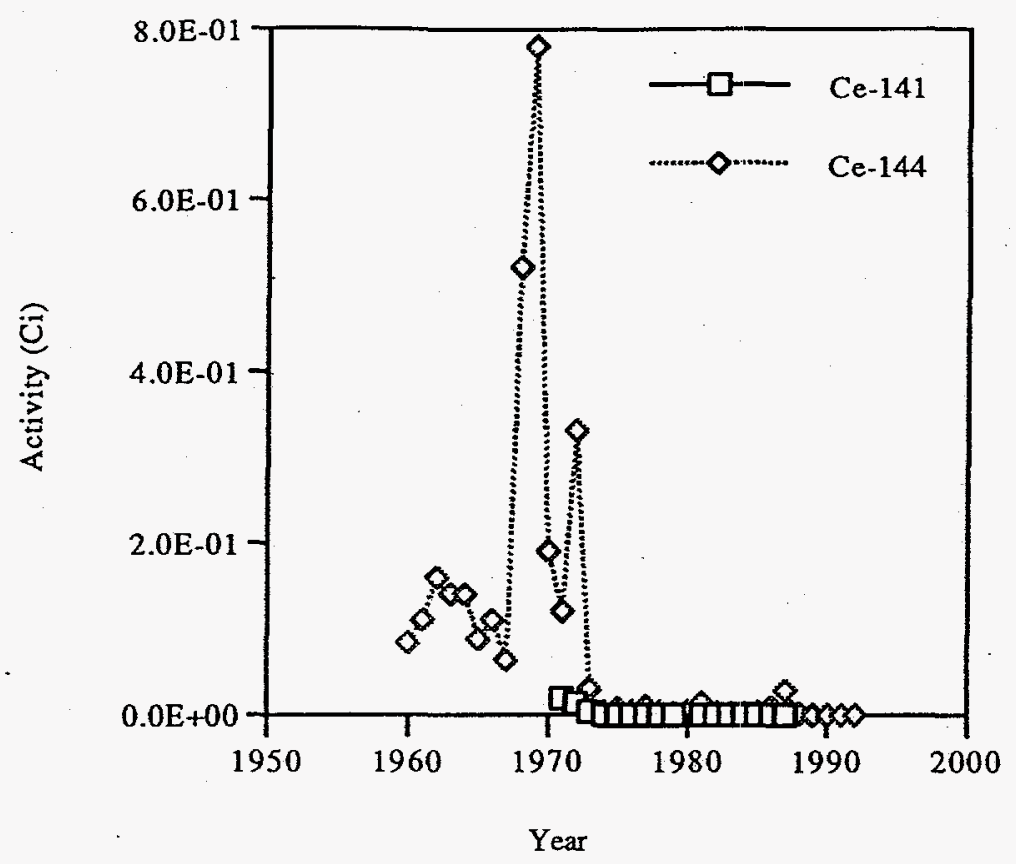

Figure 3.20. Release to Atmosphere of $\mathrm{Ce}, \mathrm{H}$ Area

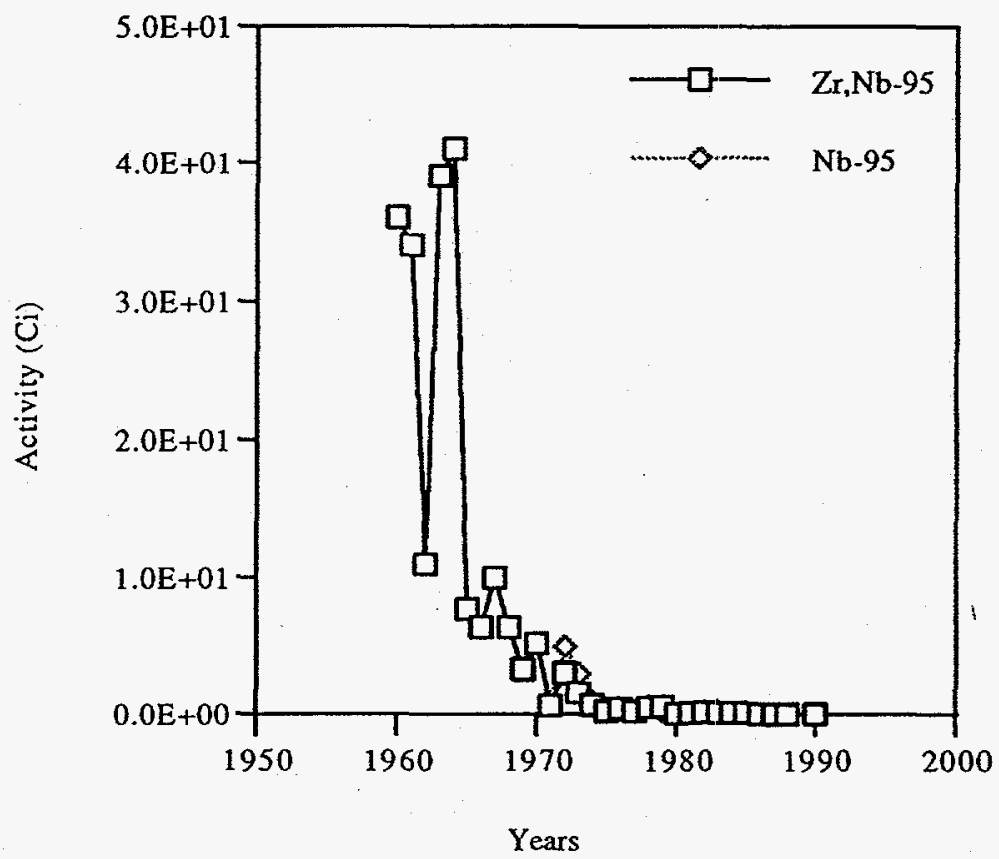

Figure 3.21. Releases to Basins of $\mathrm{Zr}-\mathrm{Nb}, \mathrm{H}$ Area 


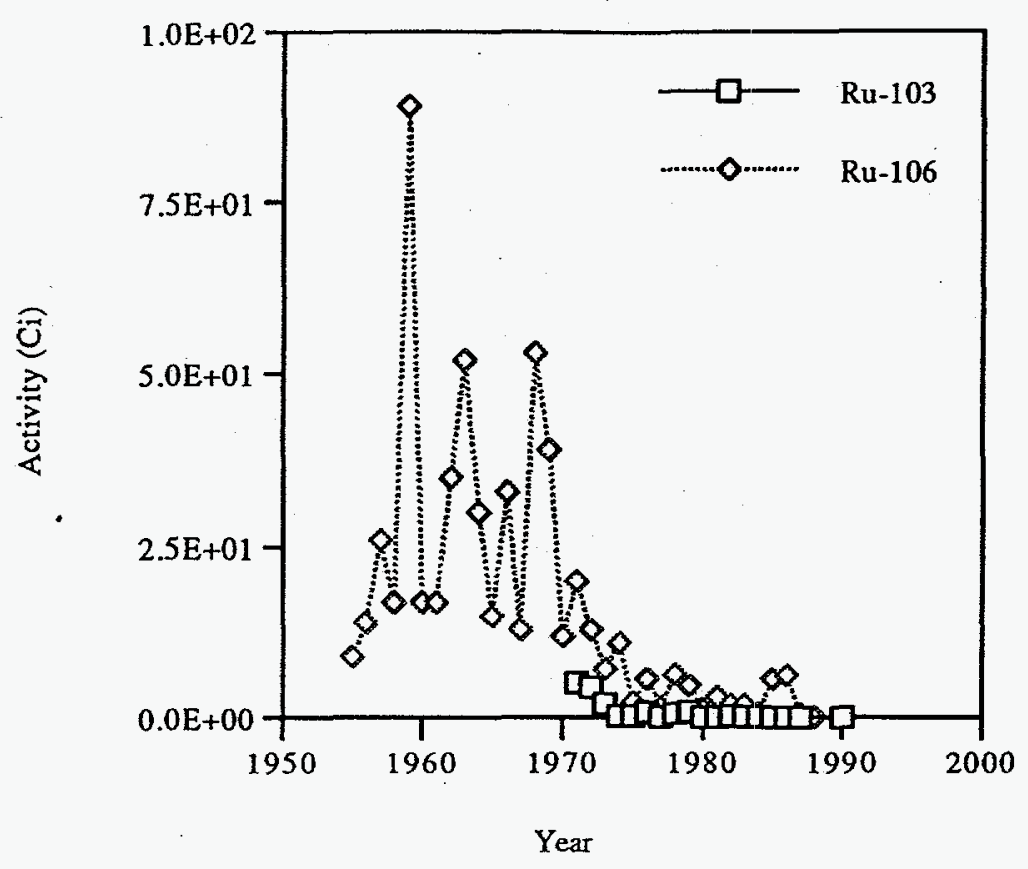

Figure 3.22. Releases to Basins of Ru, H Area

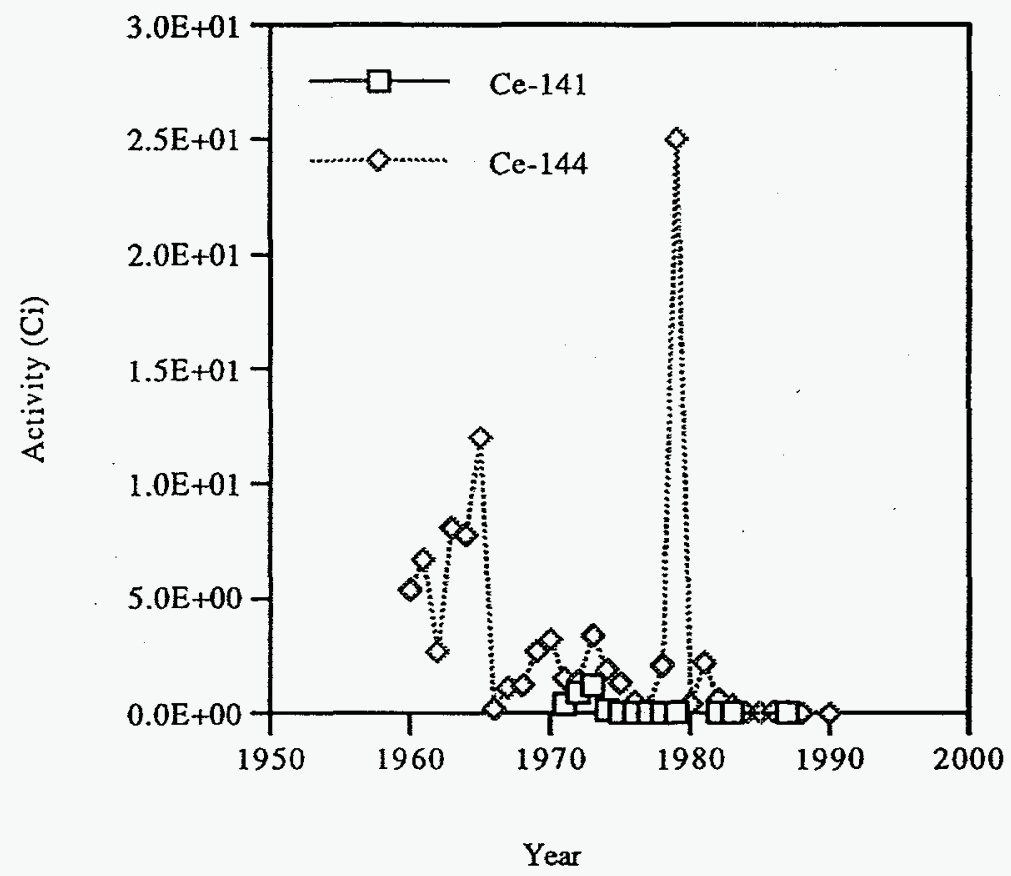

Figure 3.23. Releases to Basins of $\mathrm{Ce}, \mathrm{H}$ Area 


\section{Chapter 4. Selected Fission Product Concentrations and Transport Mechanisms}

Selected fission products released to the environment may be transported in the atmosphere, surface waters, andlor groundwaters below SRS. 
This page intentionally left blank. 


\section{Atmospheric Transport}

Atmospheric releases of ${ }^{95} \mathrm{Zr},{ }^{95} \mathrm{Nb},{ }^{103} \mathrm{Ru},{ }^{106} \mathrm{Ru},{ }^{141} \mathrm{Ce}$, and ${ }^{144} \mathrm{Ce}$ were too small to be measured in the environment. Transport of these radionuclides will be discussed in the Chapter 5 dose modeling.

\section{Surface Water Transport}

\section{Surface Waters on the Savannah River Site}

Selected fission products transported by SRS surface waters originated from three sources-fallout, atmospheric releases from SRS operations, and direct releases to streams. Fallout was deposited on the Savannah River watershed as a result of atmospheric testing of nuclear weapons in the western United States. Fallout radioactivity was deposited uniformly across the Site, except in cases of rainout, when locally heavy deposits were found (Marter 1986). Savannah River Site atmospheric fission product releases that found their way to streams were very small when compared to stream releases. Direct releases to streams have been reported (Cummins 1991) and are summarized in Table 4-1. Several streams have received cooling water from reactors and process water from separations facilities, with most of the liquid releases occurring in the reactor areas. The fission products entering the streams are assumed to be transported directly to the Savannah River, where they contributed to human dose through several pathways discussed in Chapter 5 .

Table 4-1. Releases to Streams by Area

Radioactivity (Ci)

\begin{tabular}{llll}
\hline Area & Zr,Nb-95 & Ru-103,106 & Ce-141,144 \\
\hline C & $1.8 \times 10^{1}$ & $5.6 \times 10^{0}$ & $4.0 \times 10^{1}$ \\
K & $1.6 \times 10^{1}$ & $1.1 \times 10^{1}$ & $6.5 \times 10^{1}$ \\
L & $3.3 \times 10^{1}$ & $1.6 \times 10^{1}$ & $1.6 \times 10^{2}$ \\
P & $2.1 \times 10^{1}$ & $9.4 \times 10^{0}$ & $3.5 \times 10^{1}$ \\
R & $3.6 \times 10^{1}$ & $1.7 \times 10^{1}$ & $5.1 \times 10^{1}$ \\
F & & & \\
H & $5.5 \times 10^{-1}$ & $4.7 \times 10^{-3}$ & $4.5 \times 10^{-5}$ \\
D & $4.0 \times 10^{0}$ & $4.1 \times 10^{-1}$ & $2.7 \times 10^{-1}$ \\
Total & $1.3 \times 10^{2}$ & $5.9 \times 10^{1}$ & $3.5 \times 10^{2}$
\end{tabular}

\section{Lower Three Runs Creek}

Lower Three Runs Creek has the second-largest drainage area of SRS streams. Both P Reactor and R Reactor have discharged effluents to the Lower Three Runs system. At SRS, a 2600-acre impoundment, PAR Pond, was constructed in 1958 to provide recirculating cooling water through P Reactor and R Reactor. Several smaller ponds were built between the reactors and PAR Pond to provide additional cooling for reactor cooling water before it entered PAR Pond. The average natural flow rate of Lower Three Runs Creek at the PAR Pond dam is 1 cubic meter per second. From the PAR Pond dam, the creek flows 38 $\mathrm{km}$ to the Savannah River.

\section{Upper Three Runs Creek}

Upper Three Runs Creek is the largest onsite, with a watershed of $540 \mathrm{~km}^{2}$, a natural flow rate of 7 cubic meters per second, and a length of $40 \mathrm{~km}$. Effluents were received from M Area, SRTC and, since 1988, treated water from the ETF in $H$ Area.

\section{Steel Creek}

Steel Creek is $18 \mathrm{~km}$ long and has a watershed of $90 \mathrm{~km}^{2}$. The natural flow rate is 1 cubic meter per second, but was as high as 22 cubic meters per second when both P Reactor and L Reactor discharged cooling water to the creek in the early 1960 s. P-Reactor cooling water was divertei to PAR Pond in 1964, and L Reactor was shut down in 1968, then restarted in 1985. P-Reactor disassembly basin water continued to flow to Steel Creek. L Lake was built in 1985 to provide cooling for L-Reactor discharges. Steel Creek travels about $3 \mathrm{~km}$ through a swamp before entering the Savannah River (Murphy 1991).

\section{Fourmile Branch}

Fourmile Branch has a watershed of $57 \mathrm{~km}^{2}$, is approximately $24 \mathrm{~km}$ long, and has a natural flow of 0.14 cubic meters per second. It received cooling water from C Reactor until 1985 and still receives effluent from $F$ Area and $H$ Area.

\section{Pen Branch}

Pen Branch has a watershed of $55 \mathrm{~km}^{2}$, is approximately $24 \mathrm{~km}$ long, and has a natural flow of 0.2 cubic meters per second. Once it reaches the Savannah River Swamp, the flow path becomes relatively undefined through the swamp parallel to the Savannah River for about $8 \mathrm{~km}$ before entering Steel Creek. Pen Branch received cooling water from K Reactor. 


\section{Site Stream Summary}

The total historical releases to streams is $1.3 \times 10^{2} \mathrm{Ci}$ of ${ }^{95} \mathrm{Zr}, \mathrm{Nb}, 5.9 \times 10^{1} \mathrm{Ci}$ of ${ }^{103,106} \mathrm{Ru}$, and $3.5 \times 10^{2} \mathrm{Ci}$ of ${ }^{141.144} \mathrm{Ce}$. The breakdown of releases by area is shown in Table 4-1.

\section{Savannah River}

The Savannah River forms most of the border between Georgia and South Carolina and drains approximately $25,900 \mathrm{~km}^{2}$ in eastern Georgia and western South Carolina. The flow rate averages about 285 cubic meters per second at Augusta and increases to 340 cubic meters per second downriver near Clyo, Georgia. Water from the river is used at two water treatment plants, Beaufort-Jasper and Port Wentworth.

\section{Groundwater Concentrations and Transport}

Groundwater is not a significant vector for transport of ${ }^{95} \mathrm{Zr},{ }^{95} \mathrm{Nb},{ }^{103} \mathrm{Ru},{ }^{106} \mathrm{Ru},{ }^{141} \mathrm{Ce}$, and ${ }^{144} \mathrm{Ce}$ between SRS waste sites and exposure points because the half-lives of these radionuclides are short relative to groundwater travel times. The longest lived of these radionuclides, ${ }^{104} \mathrm{Ce}$ and ${ }^{106} \mathrm{Ru}$, have half-lives of 284 days and 368 days respectively. Yet groundwater travel times between waste sites and exposure points are on the order of several to tens of years. In addition, retardation by sorption and by other geochemical processes causes these contaminants to migrate more slowly than groundwater. Thus, these radionuclides will decay to concentrations below drinking water standards and, in most cases, to below detection limits before they outcrop at exposure points.

The case of ${ }^{106} \mathrm{Ru}$ at $\mathrm{F}$ Area illustrates the insignificance of groundwater as a transport mechanism for short-lived radionuclides. It has been reported (Killian et al. 1987) that in 1983 the average concentration of ${ }^{106} \mathrm{Ru}$ in F-Area Seepage Basin influent was $308,000 \mathrm{pCi} / \mathrm{L}$. It would require this concentration 13.4 years to decay to a concentration below the primary drinking water standard of 30 $\mathrm{pCi} / \mathrm{L}$. The minimum groundwater travel time from the basins to Fourmile Branch is 8 years. If there had been no retardation of ${ }^{106} \mathrm{Ru}$ during transport, it would have arrived at the seep line along Fourmile Branch at a concentration of about $1260 \mathrm{pCi} / \mathrm{L}$, significantly lower than the initial concentration, but much higher than the drinking water standard. However, like most contaminants, sorption and other geochemical processes retarded the migration of ${ }^{106} \mathrm{Ru}$. The retardation coefficient recommended (Looney et al. 1987) for ${ }^{106} \mathrm{Ru}$ suggests that it should migrate at a rate that is $1 / 1300$ the rate of ground- water migration. If retardation is only a fraction of the recommended value, the travel time from the basins to the seep line will be sufficient to ensure that ${ }^{106} \mathrm{Ru}$ decays to concentrations below the drinking water standard prior to its appearance at the seep-line.

The groundwater monitoring data from wells near the F-Area Seepage Basins supports this analysis. Concentrations of ${ }^{\mathrm{I06}} \mathrm{Ru}$ have never consistently exceeded the detection limit in any of the wells that monitor the F-Area Seepage Basins. This suggests that ${ }^{106} \mathrm{Ru}$ either has been strongly sorbed to soils, has decayed to below detection limits, or both.

A search of the entire SRS monitoring well database (through the Geochemical Information Management System) for the 1994-1995 time period showed that ${ }^{14} \mathrm{Ce}$ and ${ }^{106} \mathrm{Ru}$ are not significant contaminants in SRS groundwater. During this time only two wells, both in H. Area, had concentrations of ${ }^{106} \mathrm{Ru}$ above the drinking water standard for one sampling period. No wells had concentrations of ${ }^{144} \mathrm{Ce}$ above one-half of the drinking water standard.

\section{References for Chapter 4}

Cummins, C. L., C. S. Hetrick, and D. K. Martin, 1991, Radioactive Releases at the Savannah River Site, 1954-1989 (U), WSRC-RP-91-684, Westinghouse Savannah River Company, Aiken, SC.

Killian, T. H., N. L. Kolb, P. Corbo, and I.W. Marine, 1987, F-Area Seepage Basins, DPST-85-704, E. I. duPont de Nemours \& Co., Savannah River Laboratory, Aiken, SC.

Looney, B. B., M. W. Grant, and C. M. King, 1987, Estimation of Geochemical Parameters for Assessing Subsurface Transport at the Savannah River Plant, DPST-85-904, E. I duPont de Nemours \& Co., Savannah River Laboratory, Aiken, $\mathrm{SC}$.

Marter, W. L., 1986, "Comments on 'Analysis of External Gamma Radiation Data around the Savannah River Plant'", Health Physics 50:652655. 


\section{Chapter 5. Assessment of Dose/Risk from SRS Selected Fission Product Releases}

This chapter describes the health impacts associated with exposure to selected fission products. The methodology used to produce dose estimates is presented. The results of a dose assessment for selected fission product releases from 1954 through 1994 are discussed. 
This page intentionally left blank. 


\section{Relationship of Dose to Risk and Health Effects}

\section{lonizing Radiation}

Ionizing radiation is radiation that has enough energy to remove electrons from the atoms through which it passes. The interaction of ionizing radiation with biological systems can induce a series of chemical reactions that can cause permanent changes in the genetic material of cells. These changes (mutations) may cause abnormal functioning within the cell or may lead to cell death.

The nature of radiation-induced cellular changes depends on the magnitude of the dose and the rate at which it is received. For the low doses and dose rates encountered in the environment from SRS releases, the most significant potential effect is cancer induction.

This is believed to be a stochastic effect (i.e., an increase in dose increases the probability of the effect, but the severity of the effect is independent of the dose).

A characteristic of stochastic risks is the absence of a threshold. In other words, it is conceivable that any dose of radiation, no matter how small, might give rise to a cancer. On the other hand, there is no way to be certain that a given dose, no matter how large, will cause a cancer in an individual.

\section{Cancer Risk Estimates}

The most comprehensive estimates of cancer induction by exposure to ionizing radiation come from studies of the atomic bomb survivors at Hiroshima and Nagasaki. Less definitive studies include those of medical patients exposed to therapeutic and diagnostic radiation. Studies of laboratory animals have increased the understanding of dose-effect relationships. The International Commission on Radiological Protection (ICRP) has evaluated all these studies and concluded that the best estimate of lifetime risk of fatal cancer for members of the general population is approximately 500 cases per $1,000,000$ person-rem (ICRP 1991). This is equivalent to one case per 2000 person-rem.

\section{Selected Fission Product Exposure and Dose to Man}

Zirconium is found mostly in the skeleton of the human body. It is not readily absorbed by the body from either the lungs or the gastrointestinal tract. Of that which is absorbed, about half is translocated to bone, where it remains with a biological half-life of 8000 days. The other half is translocated to soft tissue, where it remains with a biological half-life of 7 days (ICRP 1979a).

Niobium is a trace element in the human body found mostly in the skeleton. It is not readily absorbed by the body from either the lungs or the gastrointestinal tract. Of that which is absorbed, $71 \%$ goes to bone. In the bone, half of the niobium is retained with a biological half-life of 200 days. The remainder has a biological half-life of just 6 days (ICRP 1979a).

About $5 \%$ of the ruthenium that enters the body is absorbed. About $15 \%$ of that is excreted rapidly while the remaining $85 \%$ is distributed throughout the body. The ruthenium distributed in the body is gradually excreled; $35 \%$ with a biological half-life of 8 days, $30 \%$ with a biological half-life of 35 days, and $20 \%$ with a biological half-life of 1000 days (ICRP 1979b).

Cerium is not readily absorbed by the body from either the lungs or the gastrointestinal tract. Of that which is absorbed, $20 \%$ is translocated to bone and $80 \%$ to soft tissue. Cerium has a biological half-life of 3500 days (ICRP 1979a).

In $1988, \mathrm{DCOE}$ issued internal dose conversion factors to ensure that closes are calculated in a consistent manner at all DOE facilities (DOE 1988). The factors, based on ICRP recommendations (ICRP 1979a), are used in ccnjunction with the models described later in this chapter to calculate all the doses reported in this document.

Future changes are anticipated in the dose calculation methodology. The ICRP recently issued age-specific dose factors for ingestion of some of the more common isotopes and is developing age-specific dose factors for inhalation of radionuclides (ICRP 1989).

\section{Models of Fission Product Trans- port and Dose}

Except for tritium, most of the radioactive materials released from SRS have such low concentrations in the offsite environment that they are not detectable by conventional monitoring techniques. Therefore, radiation doses to offsite individuals and populations are calculated with mathematical models. These models use known transport mechanisms for atmospheric and liquid releases and known major pathways of exposure to man. Modeled atmospheric and aqueous dispersion are periodically verified using environmental tritium measurements (tritium is released during normal SRS operations). 
The first models used at SRS to calculate offsite doses were developed by SRTC (Cooper 1975). These models, MREM (atmospheric releases) and RIVDOSE (liquid releases), were first used in 1972. In 1982, MREM and RIVDOSE were replaced with the more technologically advanced models now in use.

Annual offsite doses at SRS are currently calculated with the transport and dose models developed for the commercial nuclear industry (NRC 1977a, NRC 1977b). The models are implemented at SRS in the following computer programs:

\section{Atmospheric Releases}

- MAXIGASP calculates maximum and average doses to offsite individuals.

- POPGASP calculates offsite population collective dose.

\section{Liquid Releases}

- LADTAP II calculates both maximum and average doses to offsite individuals and collective dose to the offsite population.

MAXIGASP and POPGASP are SRTC-modified versions of the Nuclear Regulatory Commission (NRC) programs XOQDOQ (Sagendorf et al. 1982) and GASPAR (Eckerman et al. 1980). The modifications were made to meet the requirements for input of physical and biological data specific to SRS. The basic calculations in the XOQDOQ and GASPAR programs have not been modified. LADTAP II (Simpson and McGill 1980) is an essentially unaltered version of the NRC code of the same name. LADTAP XL, a spreadsheet version of LADTAP II, was used for dose modeling for this document.

\section{Modeling Atmospheric Dispersion of Radioactive Releases}

The routine atmospheric transport of radioactive materials from SRS is evaluated on the basis of meteorological conditions measured continuously at seven onsite towers. The towers relay wind speed, wind direction, and atmospheric stability information at 1.5 -second intervals to SRTC via the WIND (Weather INformation and Display) system. A database of this information containing the 60-minute average values for the period 1987-1991 is accessed by the dispersion codes to estimate downwind concentrations of released radionuclides.

Historically, offsite doses have been calculated using $\mathrm{H}$ Area meteorology and assuming that releases occurred at the geographic center of the Site. It has been demonstrated that using data from one of the other onsite meteorological towers has little effect on the maximum individual dose and no effect on the $80-\mathrm{km}$ population dose (Hamby and Parker 1991).

The dispersion of an atmospheric release from SRS is modeled using XOQDOQ, which computes concentrations in the plume as a function of downwind distance and compass sector. The plume is depleted because of dry deposition and radioactive decay. At the user's option, plume concentrations can be reduced by taking into account the effluent's upward displacement, which results from thermal buoyancy and/or momentum effects. This option is not used at SRS (i.e,, no credit is taken for plume rise).

The plume concentration information generated by XOQDOQ then is used by the dose modeling program GASPAR to estimate doses to offsite individuals and populations. GASPAR estimates doses from a number of pathways, which are illustrated in a general sense in Figure 5.1.

The doses estimated by GASPAR are reported on a pathway-specific basis, as follows:

- Plume-external dose from radioactive materials suspended in the atmosphere

- Ground-external dose from radioactive materials deposited on the ground

- Inhalation-internal dose from inhalation of radioactive materials present in the plume

- Vegetation-internal dose from consumption of contaminated crops

- Milk-internal dose from milk produced in a contaminated area

- Meat-internal dose from consumption of meat produced in a contaminated area

The codes XOQDOQ (Bauer 1991), GASPAR (Hamby 1992), and MAXIGASP and POPGASP (Hamby 1995) have undergone comprehensive reviews in association with the WSRC quality assurance requirements for software.

\section{MAXIGASP}

The calculations required by XOQDOQ and GASPAR to estimate maximum and average individual doses are performed at SRS using the computer program MAXIGASP. MAXIGASP calculates annual average ground-level air concentrations and 50-year committed doses at a number of points along the site boundary in each of 16 compass sectors. 


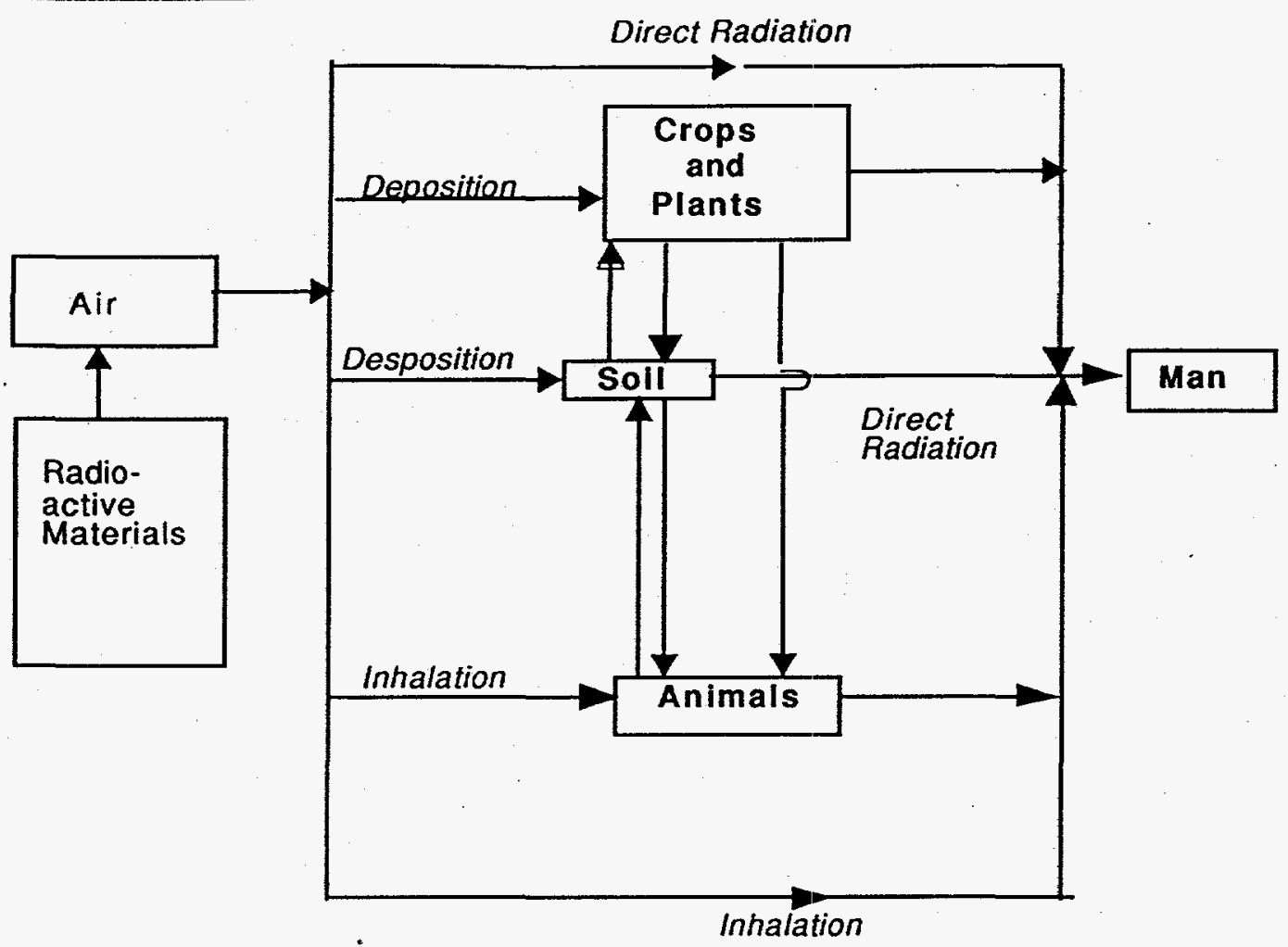

Figure 5.1. Simplified Pathways between Radioactive Materials Released to the Atmosphere and Man

The main outputs from the program are the maximum dose equivalents to an individual along the SRS perimeter. The maximally exposed individual is assumed to reside continuously at the location of highest exposure and to have living and eating habits that maximize his dose. These assumptions provide a ceiling on doses from atmospheric releases because no such individual is believed to exist.

The parameters used to calculate doses with MAXIGASP are presented in Table 5-1.

\section{POPGASP}

The calculations required by XOQDOQ and GASPAR to estimate population doses from atmospheric releases are performed at SRS using POPGASP. POPGASP calculates annual average ground-level air concentrations and annual doses for each of 160 regions ( 16 wind direction sectors at 10 distances per sector) within an 80-kilometer radius of the release location.

In addition to compass sector-specific meteorological information, POPGASP uses sector-specific data on population distribution and composition. Comparable data on milk, meat, and vegetable production/consumption also are used in the code. These databases are extensive and are available for review in the SRS annual environmental reports. With respect to the human parameters used in POPGASP, the key values are shown in Table 5-1.

\section{Modeling Doses from Liquid Releases}

The consequences of liquid releases from SRS are modeled using LADTAP XL, a spreadsheet version of LADTAP II (Liquid Annual Doses To All Persons). The potential pathways of exposure from liquid releases to the environment are shown in Figure 5.2. The pathwayspecific doses calculated by LADTAP are grouped into the following five categories:

- Potable drinking water-internal dose from consuming drinking water of Savannah River origin

- Sport fish and commercial fish-intemal dose from consuming fish of Savannah River origin

- Salt water invertebrates-internal dose from consuming shellfish from estuaries of the Savannah River

- Recreation-external dose from recreation activities (boating, swimming, and shoreline) in and along the Savannah River

- Irrigation-internal dose from foods produced by irrigation with Savannah River water. (There are no known users of the river for this purpose.) 
Table 5-1. Site-Specific Parameters for Atmospheric Releases

\section{Population Group}

$80-\mathrm{km}$ radius

555,100

(1980 Census)

\section{Maximum Individual} (MAXIGASP)

\section{Exposure Pathway}

Inhalation $\left(\mathrm{m}^{3} / \mathrm{yr}\right)$

Ingestion

Cow's milk (L/yr)

Meat $(\mathrm{kg} / \mathrm{yr})$

Leafy vegetables

(kg/yr)

Fruites, grains, and other

leafy vegetables ( $\mathrm{kg} / \mathrm{yr})$

External exposure

Transmission factor for shielding from buildings

\section{General Population (POPGASP)}

\section{Exposure Pathway}

Inhalation ( $\left.\mathrm{m}^{3} / \mathrm{yr}\right)$

Ingestion

Cow's milk (L/yr)

Meat $(\mathrm{kg} / \mathrm{yr})$

Leafy vegetables $(\mathrm{kg} / \mathrm{yr})$

Fruits, grains, and other vegetables $(\mathrm{kg} / \mathrm{yr})$

External exposure

Transmission factor for shielding from buildings
LADTAP XL estimates individual and population doses at specific downstream locations. The only removal mechanism included in the transport model as it is used at SRS is radioactive decay. No credit is taken for adsorption on stream sediments.

One major difference between LADTAP II and LADTAP $\mathrm{XL}$ is the method of calculating population dose. LADTAP II uses only a fraction of the dose from fish caught in the Savannah River. The fraction is the ratio of the 80 -kilometer harvest to the United States harvest. LADTAP XL assigns the dose from all fish to the population dose. LADTAP XL, used for dose calculations in this document, is conservative and reports the maximum possible population dose.

One major assumption inherent in the application of LADTAP XL to SRS releases is that liquid discharges undergo complete mixing in the Savannah River before reaching potentially exposed populations. This assumption is supported by repeated measurements indicating that complete mixing occurs in the river between SRS and the Highway 301 sampling station (Amett et al. 1994).

LADTAP XL generates maximum individual and population doses for all of the exposure pathways identified above. Though standard input values were provided in LADTAP II, SRS calculations are performed with site-specific information. Summary tables of principal input values used in the SRS version of LADTAP XL are shown in Table 5-2. Additional site-specific parameters for liquid releases are shown in Table 5-3.

Radioisotope concentrations in the Savannah River are diluted by the inflow of streams downriver of SRS. Additional dilution occurs at the Beaufort-Jasper, South Carolina water treatment plant from the inflow of surface water and at the Port Wentworth, Georgia water treatment plant because of the close proximity of Abercorn Creek to the intake. Because tritium is readily measured in the processed water of each system, a derived river flow rate that allows better estimates of radionuclide concentrations at these treatment plants can be calculated. 
Table 5-2. Site-Specific Parameters for Liquid Releases

Maximally Exposed Individual Dose Assessments (LADTAP XL)

\section{Site Parameters}

Savannah River flow rate

$$
\left(\mathrm{m}^{3} / \mathrm{sec}\right)
$$

Measured average

Transit time from SRS to Savannah River (hr)

Shore-width factor

\section{Human Parameters}

Water consumption (L/yr)

2. Fish consumption (kg/yr)

Shellfish consumption $(\mathrm{kg} / \mathrm{yr})$

Shoreline recreation $(\mathrm{hr} / \mathrm{yr})$

Swimming (hr/yr) 24

Maximum Individual

Boating (hr/yr)
Table 5-3. Additional Site-Specific Parameters for Liquid Releases

\section{Average Individual/Population \\ Dose Assessments \\ (LADTAP XL)}

\section{Site Parameters}

Savannah River flow rate $\left(\mathrm{m}^{3} / \mathrm{sec}\right)$

Measured average

Transit time from SRS

to Savannah River (hr)

Transit time from SRS

to water treatment plants (hr)

Retention time in water treatment system (hr)

Shore-width factor

River dilution in estuary

Aquatic food harvest, edible portions $(\mathrm{kg} / \mathrm{yr})$

Sport fish

Commercial fish

Saltwater invertebrates

390,000

\section{Human Parameters}

Water consumption ( $\mathrm{L} / \mathrm{yr})$

Fish consumption ( $\mathrm{kg} / \mathrm{yr})$

Shellfish consumption ( $\mathrm{kg} / \mathrm{yr}$ )

2

Shoreline recreation $(\mathrm{hr} / \mathrm{yr})$

960,000

Swimming (hr/yr)

160,000

Boating (hr/yr) 


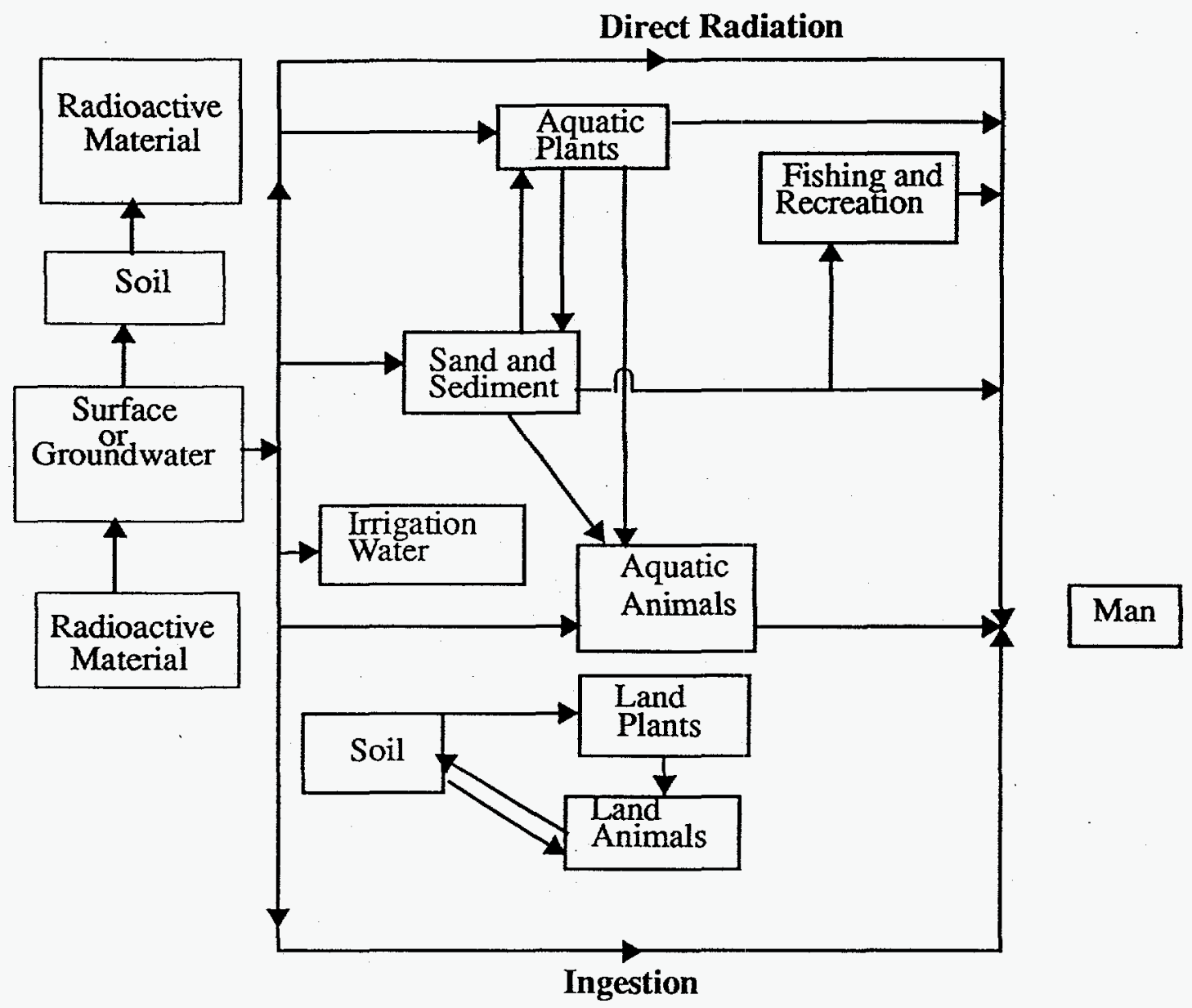

Figure 5.2. Simplified Pathways between Radioactive Materials Released to Groundwater or Surface Waters and Man 


\section{Validation of Transport Models Using Monitoring Data}

\section{Atmospheric Releases}

The radionuclide concentrations predicted by XOQDOQ are compared routinely with measured values of tritium concentrations in air to evaluate the performance of the code. (Tritium is the only radionuclide released by SRS that can be routinely detected offsite with conventional measuring techniques.) Predicted values tend to exceed observed values yet not to a degree that would indicate an excessively conservative approach.

Other comparisons of predicted and measured concentrations have been made (Simpkins 1995) and have exhibited similar results. The available data suggest that calculated concentrations of tritium in air generally are conservative estimates of actual offsite values.

\section{Liquid Releases}

Throughout the period from 1954 through 1994, SRS liquid releases were dominated by tritium. Measured, rather than estimated, tritium concentrations therefore are used for the downriver locations that are the most important in terms of dose calculations:

- just below SRS

- at the Beaufort-Jasper water treatment plant

- at the Port Wentworth water treatment plant

In addition to supplying measured tritium concentrations, such data also allow calculation of Savannah River dilution factors for these locations. Having accurate estimates of river dilution characteristics significantly enhances the ability to predict downriver concentrations of other radionuclides such as fission products.

\section{Impact of SRS Selected Fission Product Releases on the Offsite Population}

The computer codes MAXIGASP, POPGASP, and LADTAP XL have been used to calculate effective dose equivalents that have been theoretically received by segments of the offsite population from exposure to fission products over the course of Site operations. The results are shown are in Table 5-4 through 5-9 for atmospheric releases and Tables 5-10 through 5-12 for liquid releases.
Doses from Atmospheric Releases

\section{Dose from ${ }^{95} \mathrm{Zr}, \mathrm{Nb}$}

As shown in Table 5-4, the largest annual effective dose equivalent theoretically received by an adult, $1.1 \times 10^{-3}$ mrem, occurred in 1961, 1968, and 1969. The effective dose equivalent from ${ }^{95} \mathrm{Zr}, \mathrm{Nb}$ from 40 years of Site operations was $1.2 \times 10^{-2} \mathrm{mrem}$. The collective dose to all people living within 50 miles of the Site was $5.9 \times 10^{-1}$ person-rem.

\section{Dose from ${ }^{95} \mathrm{Nb}$}

The largest annual effective dose equivalent theoretically received by an adult, $5.8 \times 10^{-4} \mathrm{mrem}$, occurred in 1971 , as shown in Table 5-5. The releases of ${ }^{95} \mathrm{Nb}$ were not differentiated from ${ }^{95} \mathrm{Zx}$ prior to 1971 . The effective dose equivalent from ${ }^{95} \mathrm{Zr}, \mathrm{Nb}$ from 40 years of Site operations was $1.9 \times 10^{-3} \mathrm{mrem}$. The collective dose to all people living within 50 miles of the Site was $7.4 \times 10^{-2}$ person-rem.

Dose from ${ }^{103} \mathrm{Ru}$

The largest annual effective dose equivalent theoretically received by an adult, $2.1 \times 10^{-2} \mathrm{mrem}$, occurred in 1969, as shown in Table 5-6. The effective dose equivalent from ${ }^{103} \mathrm{Ru}$ from 40 years of Site operations was $4.2 \times 10^{-2}$ mrem. The collective dose to all people living within 50 miles of the Site was $1.4 \times 10^{\circ}$ person-rem.

Dose from ${ }^{106} \mathrm{Ru}$

The largest annual effective dose equivalent theoretically received by an adult, $1.0 \times 10^{\circ} \mathrm{mrem}$, occurred in 1978, as shown in Table 5-7. The effective dose equivalent from ${ }^{106} \mathrm{Ru}$ from 40 years of Site operations was $4.4 \times 10^{\circ}$ mrem. The collective dose to all people living within 50 miles of the Site was $1.2 \times 10^{2}$ person-rem.

Dose from ${ }^{141} \mathrm{Ce}$

The largest annual effective dose equivalent theoretically received by an adult, $8.3 \times 10^{-6} \mathrm{mrem}$, occurred in 1971 , as shown in Table 5-8. The effective dose equivalent from ${ }^{141} \mathrm{Ce}$ from 40 years of Site operations was $1.8 \times 10^{-5}$ mrem. The collective dose to all people living within 50 miles of the Site was $9.0 \times 10^{-4}$ person-rem.

Dose from ${ }^{144} \mathrm{Ce}$

The largest annual effective dose equivalent theoretically received by an adult, $6.7 \times 10^{-3} \mathrm{mrem}$, occurred in 1969 , as 
shown in Table 5-9. The effective dose equivalent from ${ }^{144} \mathrm{Ce}$ from 40 years of Site operations was $3.4 \times 10^{-2}$ mrem. The collective dose to all people living within 50 miles of the site was $1.2 \times 10^{\circ}$ person-rem.

"Maximum" individuals are hypothetical persons who live at SRS boundary and subsist on diets of locally produced milk, meat, and vegetables. No such individuals are known to exist. Nevertheless, if one examines the case of the maximally exposed adult individual living continuously at the Site perimeter throughout the period 1954-1994, the cumulative effective dose equivalent from atmospheric releases of selected fission products has been estimated at $4.5 \mathrm{mrem}$, almost all from ${ }^{106} \mathrm{Ru}$. This value is the upper bounding case and made a minor contribution to the overall dose received during that time period.

A person living in the Central Savannah River Area (CSRA) received an effective dose of approximately $11,800 \mathrm{mrem}$ from exposure to natural sources of radioactivity and an additional 2600 mrem from medical practices and various consumer products during the 40-year period (WSRC 1994). Therefore, the cumulative dose contribution to this individual from SRS atmospheric releases of selected fission products is about $0.03 \%$ of that received from sources unrelated to SRS.

Because the contribution of SRS releases of selected fission products to any individual's total radiation dose is so small, it is necessary to pool the radiation exposures from a given population if an assessment of potential health risks is desired. The population dose within an $80-\mathrm{km}$ radius is the figure of merit frequently used to make such an assessment.

The population doses reported in Tables 5-4 through 5-9 are based on 1980 census data $(555,100$ people within $80 \mathrm{~km})$ and current meteorological and dose factor data. If it is assumed that this population has lived in the SRS vicinity throughout the period of Site operations, the total collective effective dose received by the population through 1994 would be $1.2 \times 10^{2}$ person-rem, almost all from ${ }^{106} \mathrm{Ru}$.

The risks associated with this collective dose are quite small. The risk estimate using ICRP factors for the number of excess fatal cancers potentially induced by a collective dose of $1.2 \times 10^{2}$ person-rem is 0.06 . Conversely, in the same population, at the current fatal cancer frequency of $16 \%$ (EPA 1989b), there will be about 90,000 spontaneous fatal cancers from all other causes. Therefore, it is impossible to demonstrate that a relationship exists between any of the cancer deaths occurring in this population and the releases of selected fission products to the atmosphere.

\section{Individual Doses from Liquid Releases}

Dose equivalents potentially received by downstream consumers of Savannah River water and fish are shown in Tables 5-10 through 5-12. The release levels refiect contributions from all known effluents. Dose equivalents have been calculated for a "maximum" individual living just below SRS who subsisted on a diet including untreated Savannah River water and Savannah River fish. Such doses are believed to represent the bounding case for liquid releases. Drinking water doses also have been calculated for "maximum" individuals at both downstream water treatment plants and for the populations served by these plants.

\section{Dose from ${ }^{95} \mathrm{Zr}, \mathrm{Nb}$}

The maximum annual dose occurred in 1963. The effective dose equivalent to the maximally exposed individual for that year has been estimated as $4.1 \mathrm{mrem}$. If the hypothetical "maximum" exposure conditions are used as the bounding case for the 40-year period of site operations considered here, the cumulative effective dose to such an individual would be about 15 mrem. More than $99 \%$ of this dose is from eating Savannah River fish, and the remainder is from drinking untreated river water.

\section{Dose from ${ }^{106} \mathrm{Ru}$}

The maximum annual dose occurred in 1963. The effective dose equivalent to the maximally exposed individual for that year has been estimated as $0.025 \mathrm{mrem}$. If the hypothetical "maximum" exposure conditions are used as the bounding case for the 40-year period of Site operations considered here, the cumulative effective dose to such an individual would be about $0.11 \mathrm{mrem}$. Most of this dose is from drinking untreated river water.

\section{Dose from ${ }^{144} \mathrm{Ce}$}

The maximum annual dose occurred in 1963. The effective dose equivalent to the maximally exposed individual for that year has been estimated as $0.077 \mathrm{mrem}$. If the hypothetical "maximum" exposure conditions are used as the bounding case for the 40-year period of Site operations considered here, the cumulative effective dose to such an individual would be about $0.47 \mathrm{mrem}$. Almost all this dose is from drinking untreated river water.

\section{Sum of All Liquid Release Doses}

The maximally exposed individual dose from the sum of the individual radionuclide doses is $16 \mathrm{mrem}$. Because this individual's dose from non-SRS sources of radiation for that same time period would have exceeded $14,000 \mathrm{mrem}$, it may be concluded that the contribution to downstream indi- 
vidual doses by SRS selected fission products is a tiny fraction of the total dose.

\section{Collective Doses from Liquid Releases}

Collective or population doses to residents who drink Savannah River water, eat fish from the river, and eat saltwater invertebrates from the Savannah River estuary are reported in Tables 5-10 through 5-12.

Drinking water doses for users of the Beaufort-Jasper (50,000 customers) and Port Wentworth (15,000 effective consumers) water treatment plants also have been estimated. Different terminology is used to describe the two populations to reflect the difference in their compositions (Hamby 1991). The Beaufort-Jasper plant services residential areas and therefore provides full-scale domestic water service. The Port Wentworth facility serves a commercial complex in which contact with treated Savannah River water is currently limited to industrial workers who consume tap water.

If the cumulative effective doses received by both water treatment plant populations are summed, the collective dose equivalent would be about 5.9 person-rem. Using the ICRP nominal risk factor, the predicted impact of this collective dose is an estimated 0.003 excess fatal cancers in a population of 65,000 people - 10,400 of whom, at the current fatal cancer rate, are projected to succumb to cancer from all other sources.

The total population dose for liquid releases is the sum of the dose from the water treatment plant pathway (5.9 person-rem, 65,000 people) plus the dose due to other liquid pathways such as fish ( 87 person-rem, 555,100 people). The collective dose equivalent is 93 person-rem distributed among 615,000 people. The nominal risk factor predicts 0.06 fatal cancers in a population of 620,100 people $-98,000$ of whom will die of cancer from other sources.

\section{Comparisons of Selected Fission Product Doses Near SRS with Applicable Regulations}

\section{Atmospheric Releases}

The highest. hypothetical annual effective dose received by the maximally exposed individual because of atmospheric releases of selected fission products from SRS was 1.0 mrem in 1978. The current DOE and EPA annual limit for dose to members of the public because of atmospheric releases is $10 \mathrm{mrem}$ (DOE 1990; and EPA 1989a).

\section{Liquid Releases}

Selected fission product doses from drinking water sources are evaluated based on the DOE and EPA annual drinking water standard of 4 mrem (DOE 1990 and EPA 1977). At no time during Site operations has a drinking water dose from SRS selected fission product releases to the Savannah River exceeded $0.1 \mathrm{mrem}$. The maximum dose was $0.08 \mathrm{mrem}$ for Port Wentworth in 1963. It is important to note that the dose limits described above are meant to be applied to all releases of radioactivity not just selected fission products. Based on selected fission product or total releases, SRS consistently is a minor contributor to ralliation dose in the Site environment.

\section{Summary of Dosimetric Impacts}

The overall radiological impact of SRS selected fission product releases (1954-1994) on the offsite maximally exposed individual can be characterized by total dose of $16 \mathrm{mrem}$. During this same period, however, such an individual received a dose of approximately 14,000 mrem from other sources of ionizing radiation in the environment.

The impact of SRS selected fission product releases on offsite populations also has been evaluated. The total collective dose from atmospheric activation product releases (1954-1994) is estimated as $1.2 \times 10^{2}$ person-rem, distributed among 555,100 individuals. The total collective dose from liquid selected fission product releases for the same period was 93 person-rem, distributed among the 555,100 individuals listed above and an additional 65,000 individuals who get their drinking water from the Savannah River. These collective doses are minor components of the doses received from other environmental sources.

Selected fission product releases from SRS have decreased dramatically in the last decade of Site operations and present a negligible risk to the offsite environment and the population it supports. 


\section{References}

Arnett, M.W., L. K. Karapatakis and A. R. Mamatey, 1994, Savannah River Site Environmental Report for 1993. WSRC-TR-94-075, p. 79, Westinghouse Savannah River Company, Aiken, SC.

Bauer, L. R., 1991, Modeling Chronic Atmospheric Releases at the SRS: Evaluation and Verification of $X O Q$ $D O Q(U)$, WSRC-RP-91-320, Westinghouse Savannah River Company, Aiken, SC.

Cooper, R. E., 1975, Computer Programs at SRL to Evaluate Environmental Effects of SRP Operations and Postulated Accidental Releases, DPST-75-384, Savannah River Laboratory, Aiken, SC.

DOE (U.S. Department of Energy), 1988, Internal Dose Conversion Factors for Calculation of Dose to the Public, DOE/EH-0071, Washington, DC.

DOE, 1990, Radiation Protection of the Public and Environment, DOE Order 5400.5, Washington, DC.

Eckerman, K. F., F. J. Congel, A. K. Roecklein, and W. J. Pasciak, 1980, User's Guide to GASPAR Code, NUREG0597, U. S. Nuclear Regulatory Commission, Washington, DC.

EPA (U. S. Environmental Protection Agency), 1977, National Interim Primary Drinking Water Regulations, EPA 570/9-76-003, Washington, DC.

EPA, 1989a, National Emission Standards for Emissions of Radionuclides Other than Radon from Department of Energy Facilities, 40 CFR, Part 61, Subpart H, Washington, DC.

EPA, 1989b, National Emission Standards for Hazardous Air Pollutants; Regulation of Radionuclides; Final Rule and Notice of Reconsideration, 40 CFR Part 61, Federal Register, Vol. 54, No. 240, Washington, DC.

Hamby, D. M., 1991, Land and Water Use Characteristics in the Vicinity of the Savannah River Site (U), WSRC-RP91-17, Westinghouse Savannah River Company, Aiken, SC.

Hamby, D. M., and M. J. Parker, 1991, Gaussian Dispersion and Dosimetric Modeling Sensitivity to Area-Specific 19821986 Meteorological Data Collected at the Savannah River Site (U), WSRC-RP-91-909, Westinghouse Savannah River Company, Aiken, SC.
Hamby, D. M., 1992, Verification of the GASPAR Dose Assessment Module Used in MAXIGASP and POPGASP, WSRC-RP-92-418, Westinghouse Savannah River Company, Aiken, SC.

Hamby, D. M., 1995, Verification of the MAXIGASP and POPGASP Computer Codes for Environmental Dose Assessment, WSRC-RP-94-522, Westinghouse Savannah River Company, Aiken, SC.

ICRP, 1979, International Commission on Radiological Protection. Limits for Intake of Radionuclides by Workers, Oxford: Pergamon Press; ICRP Publication 30, Part 1.

ICRP, 1989, International Commission on Radiological Protection. Age-Dependent Doses to Members of the Public from Radionuclides, Oxford: Pergamon Press; ICRP Publication 56.

ICRP, 1991, International Commission on Radiological Protection, Risks Associated with Ionizing Radiations, Oxford: Pergarnon Press; ICRP Vol. 22, No. 1.

Marter, W. L., 1984, Environmental Dosimetry for Normal Operations at SRP, DPST-83-270, Rev. 1, Savannah River Laboratory, Aiken, SC.

NRC (U. S. Nuclear Regulatory Commission), 1977a, Methods for Estimating Atmospheric Transport and Dispersion of Gaseous Effluents in Routine Releases from LightWater-Cooled Reactors, Regulatory Guide 1.111, Rev. 1, Washington, DC.

NRC, 1977b, Calculation of Annual Doses to Man from Routine Releases of Reactor Effluents for the Purpose of Evaluating Compliance with 10 CFR Part 50. Appendix I, Regulatory Guide 1.109, Rev. 1, Washington, DC.

Sagendorf, J. F., J. T. Goll, and W. F. Sandusky, 1982, XOQDOQ: Computer Program for the Meteorological Evaluation of Routine Effluent Releases at Nuclear Power Stations, NUREG/CR-2919, U. S. Nuclear. Regulatory Commission, Washington, DC.

Simpson, D. B., and B. L. McGill, 1980, Users Manual for LADTAP II - A Computer Program for Calculating Radiation Exposure to Man from Routine Releases of Nuclear Reactor Effluents, NUREG/CR-1276, ORNL/TDMC-1, Oak Ridge National Laboratory, Oak Ridge, TN.

WSRC, 1994, Savannah River Site Environmental Report for 1993, Summary Report, WSRC-TR-94-076, Westinghouse Savannah River Company, Aiken, SC, p. 6. 
Chapter 5. Assessment of Dose/Risk

from SRS Selected Fission Product Releases

WSRC-TR-96-02210

Table 5-4. Atmospheric $\mathrm{Zr}, \mathrm{Nb}-95$ Releases and Dose

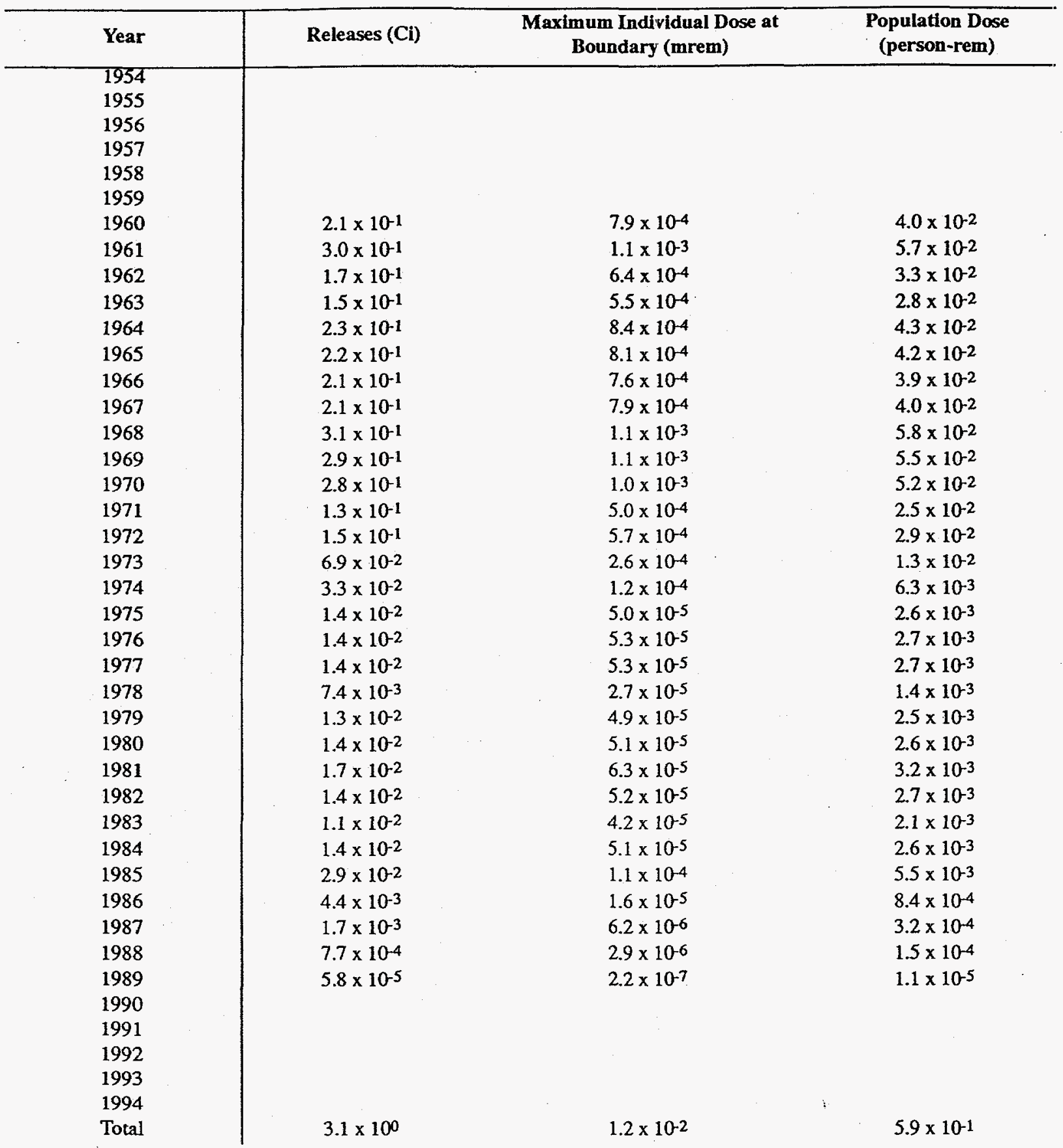


Table 5-5. Atmospheric Nb-95 Releases and Dose

\begin{tabular}{|c|c|c|c|}
\hline Year & Releases (Ci) & $\begin{array}{l}\text { Maximum Individual Dose } \\
\text { at Boundary (mrem) }\end{array}$ & $\begin{array}{l}\text { Population Dose } \\
\text { (person-rem) }\end{array}$ \\
\hline \multicolumn{4}{|l|}{1954} \\
\hline \multicolumn{4}{|l|}{1955} \\
\hline \multicolumn{4}{|l|}{1956} \\
\hline \multicolumn{4}{|l|}{1957} \\
\hline \multicolumn{4}{|l|}{1958} \\
\hline \multicolumn{4}{|l|}{1959} \\
\hline \multicolumn{4}{|l|}{1960} \\
\hline \multicolumn{4}{|l|}{1961} \\
\hline \multicolumn{4}{|l|}{1962} \\
\hline \multicolumn{4}{|l|}{1963} \\
\hline \multicolumn{4}{|l|}{1964} \\
\hline \multicolumn{4}{|l|}{1965} \\
\hline \multicolumn{4}{|l|}{1966} \\
\hline \multicolumn{4}{|l|}{1967} \\
\hline \multicolumn{4}{|l|}{1968} \\
\hline \multicolumn{4}{|l|}{1969} \\
\hline \multicolumn{4}{|l|}{1970} \\
\hline 1971 & $3.4 \times 10^{-1}$ & $5.8 \times 10^{-4}$ & $2.3 \times 10^{-2}$ \\
\hline 1972 & $2.0 \times 10^{-1}$ & $3.5 \times 10^{-4}$ & $1.4 \times 10^{-2}$ \\
\hline 1973 & $7.6 \times 10^{-2}$ & $1.3 \times 10^{-4}$ & $5.2 \times 10^{-3}$ \\
\hline 1974 & $1.2 \times 10^{-1}$ & $2.1 \times 10^{-4}$ & $8.5 \times 10^{-3}$ \\
\hline 1975 & $2.5 \times 10^{-2}$ & $4.3 \times 10^{-5}$ & $1.7 \times 10^{-3}$ \\
\hline 1976 & $2.7 \times 10^{-2}$ & $4.6 \times 10^{-5}$ & $1.8 \times 10^{-3}$ \\
\hline 1977 & $3.7 \times 10^{-2}$ & $6.4 \times 10^{-5}$ & $2.6 \times 10^{-3}$ \\
\hline 1978 & $1.9 \times 10^{-2}$ & $3.3 \times 10^{-5}$ & $1.3 \times 10^{-3}$ \\
\hline 1979 & $2.7 \times 10^{-2}$ & $4.6 \times 10^{-5}$ & $1.8 \times 10^{-3}$ \\
\hline 1980 & $1.7 \times 10^{-2}$ & $3.0 \times 10^{-5}$ & $1.2 \times 10^{-3}$ \\
\hline 1981 & $6.4 \times 10^{-2}$ & $1.1 \times 10^{-4}$ & $4.4 \times 10^{-3}$ \\
\hline 1982 & $1.6 \times 10^{-2}$ & $2.8 \times 10^{-5}$ & $1.1 \times 10^{-3}$ \\
\hline 1983 & $1.8 \times 10^{-2}$ & $3.1 \times 10^{-5}$ & $1.3 \times 10^{-3}$ \\
\hline 1984 & $1.9 \times 10^{-2}$ & $3.3 \times 10^{-5}$ & $1.3 \times 10^{-3}$ \\
\hline 1985 & $4.9 \times 10^{-2}$ & $8.4 \times 10^{-5}$ & $3.4 \times 10^{-3}$ \\
\hline 1986 & $9.2 \times 10^{-3}$ & $1.6 \times 10^{-5}$ & $6.3 \times 10^{-4}$ \\
\hline 1987 & $3.3 \times 10^{-3}$ & $5.7 \times 10^{-6}$ & $2.3 \times 10^{-4}$ \\
\hline 1988 & $2.2 \times 10^{-3}$ & $3.7 \times 10^{-6}$ & $1.5 \times 10^{-4}$ \\
\hline 1989 & $1.3 \times 10^{-4}$ & $2.3 \times 10^{-7}$ & $9.0 \times 10^{-6}$ \\
\hline 1990 & & & . \\
\hline \multicolumn{4}{|l|}{1991} \\
\hline \multicolumn{4}{|l|}{1992} \\
\hline 1993 & & & $r$ \\
\hline \multicolumn{4}{|l|}{1994} \\
\hline Total & $1.1 \times 10^{0}$ & $1.9 \times 10^{-3}$ & $7.4 \times 10^{-2}$ \\
\hline
\end{tabular}


Chapter 5. Assessment of Dose/Risk

from SRS Selected Fission Product Releases

Table 5-6. Atmospheric Ru-103 Releases and Dose

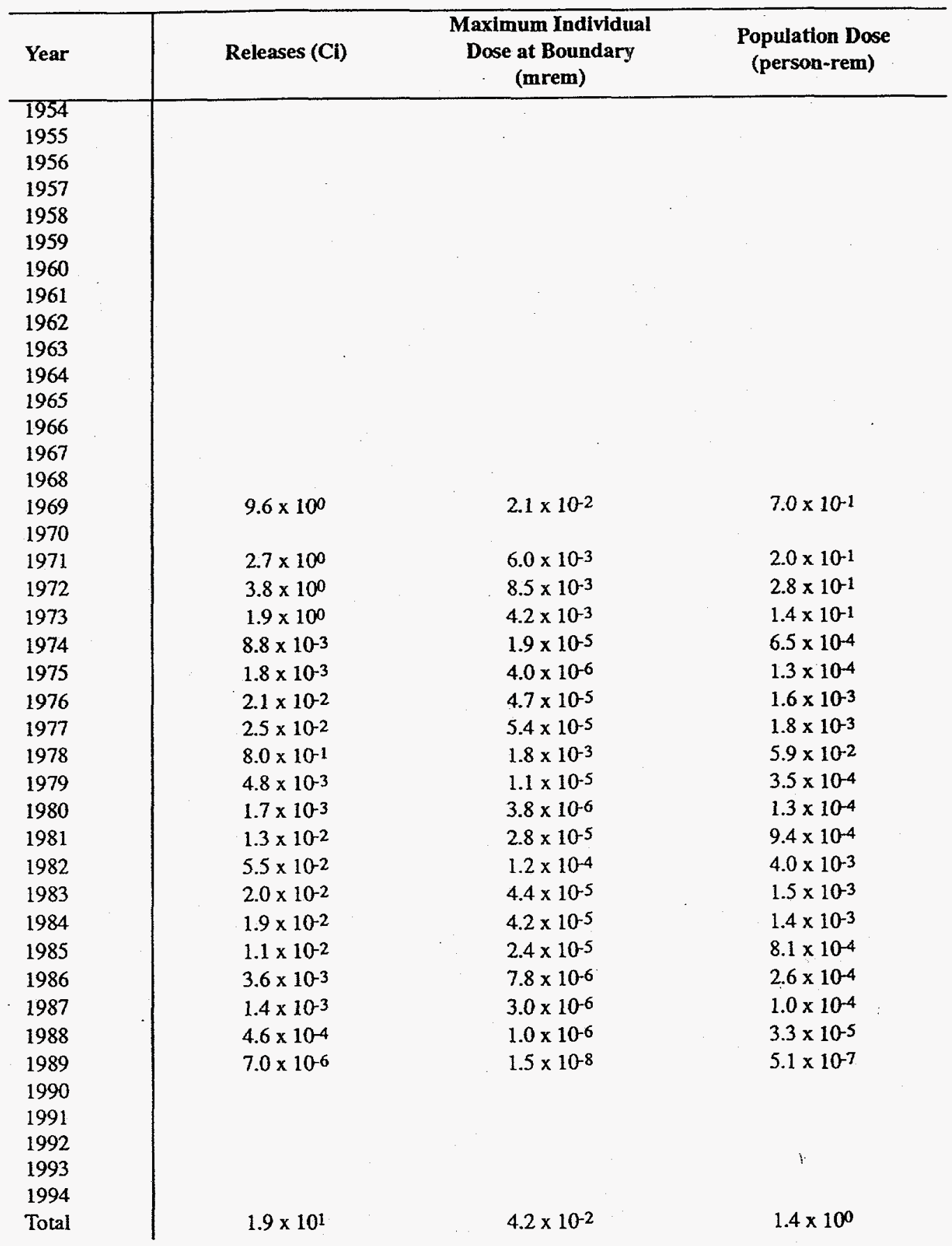


Table 5-7. Atmospheric Ru-106 Releases and Dose

\begin{tabular}{|c|c|c|c|}
\hline Year & Releases (Ci) & $\begin{array}{l}\text { Maximum Individual } \\
\text { Dose at Boundary (nirem) }\end{array}$ & $\begin{array}{l}\text { Population Dose } \\
\text { (person-rem) }\end{array}$ \\
\hline 1954 & & & \\
\hline 1955 & $2.5 \times 101$ & $8.0 \times 10^{-1}$ & $2.2 \times 10^{1}$ \\
\hline 1956 & $6.3 \times 10^{0}$ & $2.0 \times 10^{-1}$ & $5.4 \times 10^{0}$ \\
\hline 1957 & $1.2 \times 100$ & $3.9 \times 10^{-2}$ & $1.1 \times 10^{0}$ \\
\hline 1958 & $6.2 \times 10^{-1}$ & $2.0 \times 10^{-2}$ & $5.3 \times 10^{-1}$ \\
\hline 1959 & $1.0 \times 10^{1}$ & $3.2 \times 10^{-1}$ & $8.6 \times 10^{0}$ \\
\hline 1960 & $8.9 \times 10^{0}$ & $2.8 \times 10^{-1}$ & $7.6 \times 10^{0}$ \\
\hline 1961 & $3.9 \times 10^{0}$ & $1.2 \times 10^{-1}$ & $3.3 \times 10^{0}$ \\
\hline 1962 & $2.8 \times 10^{0}$ & $8.7 \times 10^{-2}$ & $2.4 \times 10^{0}$ \\
\hline 1963 & $3.9 \times 100$ & $1.2 \times 10^{-1}$ & $3.3 \times 10^{0}$ \\
\hline 1964 & $2.6 \times 10^{0}$ & $8.2 \times 10^{-2}$ & $2.2 \times 10^{0}$ \\
\hline 1965 & $2.8 \times 100$ & $8.8 \times 10^{-2}$ & $2.4 \times 10^{0}$ \\
\hline 1966 & $4.6 \times 10^{0}$ & $1.5 \times 10^{-1}$ & $3.9 \times 10^{0}$ \\
\hline 1967 & $4.2 \times 10^{-1}$ & $1.3 \times 10^{-2}$ & $3.6 \times 10^{-1}$ \\
\hline 1968 & $2.0 \times 10^{1}$ & $6.4 \times 10^{-1}$ & $1.7 \times 10^{1}$ \\
\hline 1969 & $4.1 \times 10^{0}$ & $1.3 \times 10^{-1}$ & $3.5 \times 10^{0}$ \\
\hline 1970 & $6.8 \times 10^{-1}$ & $2.1 \times 10^{-2}$ & $5.8 \times 10^{-1}$ \\
\hline 1971 & $2.9 \times 10^{0}$ & $9.2 \times 10^{-2}$ & $2.5 \times 10^{0}$ \\
\hline 1972 & $3.4 \times 10^{0}$ & $1.1 \times 10^{-1}$ & $2.9 \times 10^{0}$ \\
\hline 1973 & $1.3 \times 10^{0}$ & $4.2 \times 10^{-2}$ & $1.1 \times 10^{0}$ \\
\hline 1974 & $1.4 \times 10^{-1}$ & $4.3 \times 10^{-3}$ & $1.2 \times 10^{-1}$ \\
\hline 1975 & $3.7 \times 10^{-2}$ & $1.2 \times 10^{-3}$ & $3.2 \times 10^{-2}$ \\
\hline 1976 & $2.6 \times 10^{-1}$ & $8.3 \times 10^{-3}$ & $2.3 \times 10^{-1}$ \\
\hline 1977 & $1.4 \times 10^{-1}$ & $4.4 \times 10^{-3}$ & $1.2 \times 10^{-1}$ \\
\hline 1978 & $3.2 \times 10^{1}$ & $1.0 \times 10^{0}$ & $2.8 \times 10^{1}$ \\
\hline 1979 & $5.5 \times 10^{-2}$ & $1.7 \times 10^{-3}$ & $4.7 \times 10^{-2}$ \\
\hline 1980 & $6.0 \times 10^{-2}$ & $1.9 \times 10^{-3}$ & $5.1 \times 10^{-2}$ \\
\hline 1981 & $7.9 \times 10^{-2}$ & $2.5 \times 10^{-3}$ & $6.8 \times 10^{-2}$ \\
\hline 1982 & $1.8 \times 10^{-1}$ & $5.8 \times 10^{-3}$ & $1.6 \times 10^{-1}$ \\
\hline 1983 & $8.1 \times 10^{-2}$ & $2.6 \times 10^{-3}$ & $6.9 \times 10^{-2}$ \\
\hline 1984 & $1.5 \times 10^{-1}$ & $4.8 \times 10^{-3}$ & $1.3 \times 10^{-1}$ \\
\hline 1985 & $4.4 \times 10^{-2}$ & $1.4 \times 10^{-3}$ & $3.8 \times 10^{-2}$ \\
\hline 1986 & $5.9 \times 10^{-2}$ & $1.9 \times 10^{-3}$ & $5.0 \times 10^{-2}$ \\
\hline 1987 & $4.5 \times 10^{-2}$ & $1.4 \times 10^{-3}$ & $3.9 \times 10^{-2}$ \\
\hline 1988 & $3.0 \times 10^{-2}$ & $9.5 \times 10^{-4}$ & $2.6 \times 10^{2}$ \\
\hline 1989 & $3.3 \times 10^{-3}$ & $1.0 \times 10^{-4}$ & $2.8 \times 10^{-3}$ \\
\hline 1990 & $1.2 \times 10^{-3}$ & $3.7 \times 10^{-5}$ & $1.0 \times 10^{-3}$ \\
\hline 1991 & $4.4 \times 10^{-4}$ & $1.4 \times 10^{-5}$ & $3.8 \times 10^{-4}$ \\
\hline 1992 & $1.8 \times 10^{-6}$ & $5.7 \times 10^{-8}$ & $1.5 \times 10^{-6}$ \\
\hline 1993 & $4.0 \times 10^{-6}$ & $1.3 \times 10^{-7}$ & $3.4 \times 10^{-6}$ \\
\hline 1994 & $1.2 \times 10^{-8}$ & $3.8 \times 10^{-10}$ & $1.0 \times 10^{-8}$ \\
\hline Total & $1.4 \times 10^{2}$ & $4.4 \times 10^{0}$ & $1.2 \times 10^{2}$ \\
\hline
\end{tabular}


Chapter 5. Assessment of Dose/Risk

from SRS Selected Fission Product Releases

Table 5-8. Atmospheric Ce-141 Releases and Dose

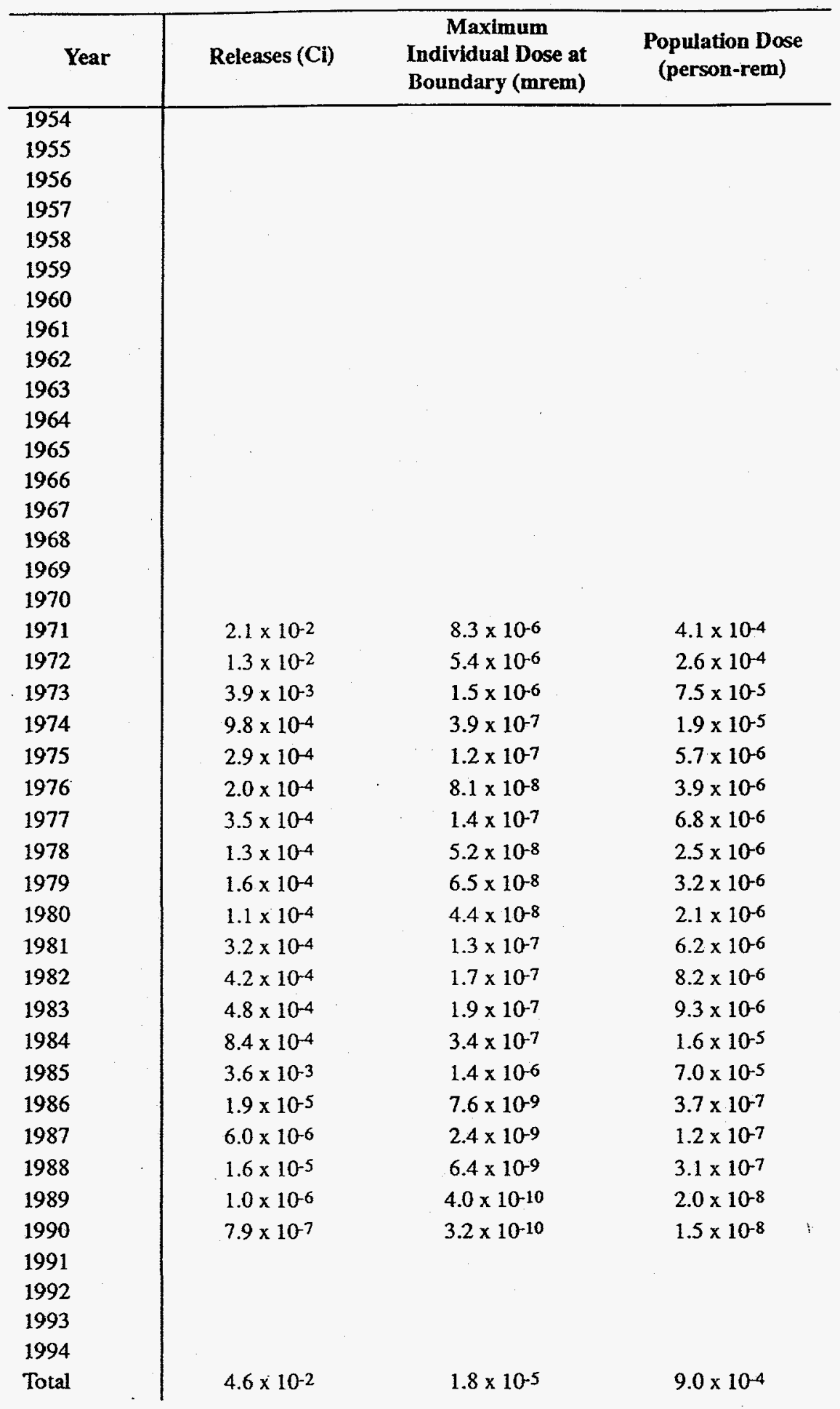


Table 5-9. Atmospheric Ce-144 Releases and Dose

\begin{tabular}{|c|c|c|c|}
\hline Year & Releases (Ci) & $\begin{array}{c}\text { Maximum Individual } \\
\text { Dose at Boundary (mrem) }\end{array}$ & $\begin{array}{l}\text { Population Dose } \\
\text { (person-rem) }\end{array}$ \\
\hline \multicolumn{4}{|l|}{1954} \\
\hline \multicolumn{4}{|l|}{1955} \\
\hline \multicolumn{4}{|l|}{1956} \\
\hline \multicolumn{4}{|l|}{1957} \\
\hline \multicolumn{4}{|l|}{1958} \\
\hline \multicolumn{4}{|l|}{1959} \\
\hline 1960 & $2.4 \times 10^{-1}$ & $2.0 \times 10^{-3}$ & $7.2 \times 10^{-2}$ \\
\hline 1961 & $2.8 \times 10^{-1}$ & $2.3 \times 10^{-3}$ & $8.3 \times 10^{-2}$ \\
\hline 1962 & $2.2 \times 10^{-1}$ & $1.8 \times 10^{-3}$ & $6.4 \times 10^{-2}$ \\
\hline 1963 & $2.4 \times 10^{-1}$ & $1.9 \times 10^{-3}$ & $7.0 \times 10^{-2}$ \\
\hline 1964 & $3.2 \times 10^{-1}$ & $2.6 \times 10^{-3}$ & $9.5 \times 10^{-2}$ \\
\hline 1965 & $2.4 \times 10^{-1}$ & $2.0 \times 10^{-3}$ & $7.0 \times 10^{-2}$ \\
\hline 1966 & $1.8 \times 10^{-1}$ & $1.4 \times 10^{-3}$ & $5.2 \times 10^{-2}$ \\
\hline 1967 & $9.3 \times 10^{-2}$ & $7.7 \times 10^{-4}$ & $2.8 \times 10^{-2}$ \\
\hline 1968 & $5.5 \times 10^{-1}$ & $4.5 \times 10^{-3}$ & $1.6 \times 10^{-1}$ \\
\hline 1969 & $8.1 \times 10^{-1}$ & $6.7 \times 10^{-3}$ & $2.4 \times 10^{-1}$ \\
\hline 1970 & $2.3 \times 10^{-1}$ & $1.9 \times 10^{-3}$ & $6.8 \times 10^{-2}$ \\
\hline 1971 & $1.4 \times 10^{-1}$ & $1.1 \times 10^{-3}$ & $4.1 \times 10^{-2}$ \\
\hline 1972 & $3.3 \times 10^{-1}$ & $2.8 \times 10^{-3}$ & $9.9 \times 10^{-2}$ \\
\hline 1973 & $3.9 \times 10^{-2}$ & $3.2 \times 10^{-4}$ & $1.2 \times 10^{-2}$ \\
\hline 1974 & $2.2 \times 10^{-2}$ & $1.8 \times 10^{-4}$ & $6.6 \times 10^{-3}$ \\
\hline 1975 & $1.6 \times 10^{-2}$ & $1.3 \times 10^{-4}$ & $4.8 \times 10^{-3}$ \\
\hline 1976 & $1.1 \times 10^{-2}$ & $9.4 \times 10^{-5}$ & $3.4 \times 10^{-3}$ \\
\hline 1977. & $1.5 \times 10^{-2}$ & $1.2 \times 10^{-4}$ & $4.4 \times 10^{-3}$ \\
\hline 1978 & $1.4 \times 10^{-2}$ & $1.1 \times 10^{-4}$ & $4.1 \times 10^{-3}$ \\
\hline 1979 & $1.7 \times 10^{-2}$ & $1.4 \times 10^{-4}$ & $5.2 \times 10^{-3}$ \\
\hline 1980 & $1.5 \times 10^{-2}$ & $1.2 \times 10^{-4}$ & $4.5 \times 10^{-3}$ \\
\hline 1981 & $2.7 \times 10^{-2}$ & $2.2 \times 10^{-4}$ & $8.0 \times 10^{-3}$ \\
\hline 1982 & $7.8 \times 10^{-3}$ & $6.4 \times 10^{-5}$ & $2.3 \times 10^{-3}$ \\
\hline 1983 & $8.9 \times 10^{-3}$ & $7.3 \times 10^{-5}$ & $2.6 \times 10^{-3}$ \\
\hline 1984 & $1.3 \times 10^{-2}$ & $1.1 \times 10^{-4}$ & $3.8 \times 10^{-3}$ \\
\hline 1985 & $5.1 \times 10^{-2}$ & $4.2 \times 10^{-4}$ & $1.5 \times 10^{-2}$ \\
\hline 1986 & $1.1 \times 10^{-2}$ & $9.1 \times 10^{-5}$ & $3.3 \times 10^{-3}$ \\
\hline 1987 & $3.2 \times 10^{-2}$ & $2.6 \times 10^{-4}$ & $9.4 \times 10^{-3}$ \\
\hline 1988 & $4.5 \times 10^{-3}$ & $3.7 \times 10^{-5}$ & $1.3 \times 10^{-3}$ \\
\hline 1989 & $7.6 \times 10^{-4}$ & $6.2 \times 10^{-6}$ & $2.2 \times 10^{-4}$ \\
\hline 1990 & $3.1 \times 10^{-4}$ & $2.5 \times 10^{-6}$ & $9.1 \times 10^{-5}$ \\
\hline 1991 & $6.5 \times 10^{-7}$ & $5.4 \times 10^{-9}$ & $1.9 \times 10^{-7}$ \\
\hline 1992 & $1.2 \times 10^{-7}$ & $9.9 \times 10^{-10}$ & $3.6 \times 10^{-8}$ \\
\hline 1993 & & & \\
\hline 1994 & & & \\
\hline Total & $4.2 \times 10^{0}$ & $3.4 \times 10^{-2}$ & $1.2 \times 100$ \\
\hline
\end{tabular}


Table 5-10. Stream Releases of $\mathrm{Zr}, \mathrm{Nb}-95$ and Dose

\begin{tabular}{|c|c|c|c|c|c|c|c|c|c|c|c|}
\hline Year & $\begin{array}{c}\text { River } \\
\text { Flow } \\
\text { Rate } \\
\left(\mathrm{m}^{3} / \mathrm{s}\right) \\
\end{array}$ & $\begin{array}{c}\text { B-J } \\
\text { Derived } \\
\text { Fiow Rate } \\
(\mathrm{m} 3 \mathrm{~s} / \mathrm{s})\end{array}$ & $\begin{array}{c}\text { PW } \\
\text { Derived Flow } \\
\text { Rate } \\
\left(\mathrm{m}^{3 / s}\right) \\
\end{array}$ & $\begin{array}{c}\text { Releases } \\
\text { to } \\
\text { Streams } \\
\text { (Ci) } \\
\end{array}$ & $\begin{array}{l}\text { Max Ind. } \\
\text { Below SRS } \\
\text { (mrem) }\end{array}$ & $\begin{array}{c}\text { Max } \\
\text { lnd } \\
\text { BJ } \\
\text { (mrem) } \\
\end{array}$ & $\begin{array}{c}\text { Max } \\
\text { Ind } \\
\text { PW } \\
\text { (mrem) }\end{array}$ & $\begin{array}{c}\text { Pop } \\
\text { Dose } \\
\text { BJ } \\
\text { (per-sem) } \\
\end{array}$ & $\begin{array}{c}\text { Pop } \\
\text { Dose } \\
\text { PW } \\
\text { (per-rem) }\end{array}$ & $\begin{array}{c}\text { Pop Dose } \\
80 \mathrm{~km} \\
\text { (per-rem) }\end{array}$ & $\begin{array}{l}\text { Pop Dose Toull } \\
\text { (per-sem) }\end{array}$ \\
\hline 1954 & 209 & & 263 & & & & & & & & \\
\hline 1955 & 169 & & 213 & & & & & & & & \\
\hline 1956 & 179 & & 225 & & & & & & & & \\
\hline 1957 & 235 & & 297 & & & & & & & & \\
\hline 1958 & 313 & & 394 & & & & & & & & \\
\hline 1959 & 276 & & 348 & & & & & & & & \\
\hline 1960 & 371 & & 468 & $7.5 \times 100$ & $8.0 \times 10^{-1}$ & & $1.2 \times 10^{-3}$ & & $9.1 \times 10^{-3}$ & $1.3 \times 10^{0}$ & $1.3 \times 100$ \\
\hline 1961 & 309 & & 389 & $7.0 \times 100$ & $9.0 \times 10^{-1}$ & & $1.4 \times 10^{-3}$ & & $1.0 \times 10^{-2}$ & $1.5 \times 10^{0}$ & $1.5 \times 100$ \\
\hline 1962 & 300 & & 377 & $1.7 \times 10^{1}$ & $2.3 \times 10^{0}$ & & $3.5 \times 10^{-3}$ & & $2.6 \times 10.2$ & $3.7 \times 100$ & $3.8 \times 10^{0}$ \\
\hline 1963 & 315 & & 397 & $3.3 \times 101$ & $4.1 \times 100$ & & $6.3 \times 10^{-3}$ & & $4.6 \times 10^{-2}$ & $6.7 \times 10^{0}$ & $6.8 \times 10^{0}$ \\
\hline 1964 & 580 & & 731 & $2.0 \times 10^{1}$ & $1.4 \times 100$ & & $2.1 \times 10^{-3}$ & & $1.5 \times 10^{-2}$ & $22 \times 10^{0}$ & $2.2 \times 10^{0}$ \\
\hline 1965 & 362 & 800 & 456 & $6.2 \times 100$ & $6.8 \times 10^{-1}$ & $5.9 \times 10^{-4}$ & $1.0 \times 10^{-3}$ & $1.5 \times 10^{-2}$ & $7.7 \times 10^{0.3}$ & $1.1 \times 10^{0}$ & $1.1 \times 100$ \\
\hline 1966 & 316 & 520 & 399 & $8.0 \times 100$ & $1.0 \times 100$ & $1.2 \times 10^{-3}$ & $1.5 \times 10^{-3}$ & $29 \times 10^{-2}$ & $1.1 \times 10^{-2}$ & $1.6 \times 10^{0}$ & $1.7 \times 10^{0}$ \\
\hline 1967 & 299 & 625 & 377 & $1.4 \times 101$ & $1.8 \times 100$ & $1.7 \times 10^{-3}$ & $2.8 \times 10^{-3}$ & $4.2 \times 10^{-2}$ & $2.1 \times 10-2$ & $3.0 \times 100$ & $3.1 \times 100$ \\
\hline 1968 & 273 & 470 & 343 & $8.1 \times 10^{0}$ & $1.2 \times 10^{0}$ & $1.3 \times 10^{-3}$ & $1.8 \times 10^{-3}$ & $3.3 \times 10^{-2}$ & $1.3 \times 10^{-2}$ & $1.9 \times 10^{0}$ & $2.0 \times 10^{0}$ \\
\hline 1969 & 310 & 624 & 390 & $3.6 \times 10^{0}$ & $4.6 \times 10^{-1}$ & $4.4 \times 10^{-4}$ & $7.1 \times 10^{-4}$ & $1.1 \times 10^{-2}$ & $5.2 \times 10^{0.3}$ & $7.6 \times 10^{-1}$ & $7.7 \times 10^{-1}$ \\
\hline 1970 & 232 & 772 & 293 & $2.8 \times 10^{0}$ & $4.9 \times 10^{-1}$ & $28 \times 10^{-4}$ & $7.4 \times 10^{-4}$ & $7.0 \times 10^{0.3}$ & $5.5 \times 10^{-3}$ & $8.0 \times 10^{-1}$ & $8.1 \times 10^{-1}$ \\
\hline 1971 & 303 & 1245 & 381 & $8.9 \times 10^{-1}$ & $1.2 \times 10^{-1}$ & $5.5 \times 10.5$ & $1.8 \times 10^{-4}$ & $1.4 \times 10^{-3}$ & $1.3 \times 10^{-3}$ & $1.9 \times 10^{-1}$ & $1.9 \times 10^{-1}$ \\
\hline 1972 & $3: 8$ & 775 & 401 & $9.9 \times 10^{-2}$ & $1.2 \times 10-2$ & $9.8 \times 10.6$ & $1.9 \times 10^{-5}$ & $2.4 \times 10^{-4}$ & $1.4 \times 10^{-4}$ & $20 \times 10^{-2}$ & $2.1 \times 10^{-2}$ \\
\hline 1973 & 409 & 656 & 468 & $1.9 \times 10^{-1}$ & $1.9 \times 10^{-2}$ & $2.2 \times 10^{-5}$ & $3.1 \times 10^{-5}$ & $5.6 \times 10^{-4}$ & $2.3 \times 10^{-4}$ & $3.1 \times 10^{-2}$ & $3.1 \times 10^{-2}$ \\
\hline 1974 & 314 & 640 & 373 & $2.3 \times 10^{-1}$ & $2.9 \times 10^{-2}$ & $2.8 \times 10.5$ & $4.8 \times 10^{-5}$ & $6.9 \times 10^{4}$ & $3.5 \times 10^{-4}$ & $4.8 \times 10^{-2}$ & $5.0 \times 10^{-2}$ \\
\hline 1975 & 436 & 877 & 538 & $3.9 \times 10^{-2}$ & $3.5 \times 10^{-3}$ & $3.4 \times 10^{-6}$ & $5.5 \times 10^{-6}$ & $8.4 \times 10^{-5}$ & $4.1 \times 10^{-3}$ & $5.8 \times 10^{-3}$ & $5.9 \times 10^{-3}$ \\
\hline 1976 & 394 & 996 & 472 & $1.7 \times 10^{-2}$ & $1.7 \times 10^{-3}$ & $1.3 \times 10^{-6}$ & $2.8 \times 10^{-6}$ & $3.2 \times 10^{-5}$ & $2.0 \times 10^{-5}$ & $2.8 \times 10^{-3}$ & $2.9 \times 10^{-3}$ \\
\hline 1977 & 330 & 562 & 433 & $9.4 \times 10^{-2}$ & $1.1 \times 10^{-2}$ & $1.3 \times 10.5$ & $1.7 \times 10.5$ & $3.2 \times 10^{-4}$ & $1.2 \times 10^{-4}$ & $1.9 \times 10^{-2}$ & $1.9 \times 10^{-2}$ \\
\hline 1978 & 298 & 689 & 324 & $3.5 \times 10^{-4}$ & $4.7 \times 10^{-5}$ & $3.9 \times 10^{-8}$ & $8.2 \times 10^{-8}$ & $9.6 \times 10^{-7}$ & $6.1 \times 10^{-7}$ & $7.6 \times 10^{-5}$ & $7.8 \times 10.5$ \\
\hline 1979 & 375 & 989 & 495 & & & & & & & & \\
\hline 1980 & 374 & 863 & 488 & & & & & & & & \\
\hline 1981 & 187 & 331 & 243 & & & & & & & & \\
\hline 1982 & 203 & 555 & 287 & & & & & & & & \\
\hline 1983 & 350 & 361 & 417 & & & & & & & & \\
\hline 1984 & 361 & 747 & 487 & & & & & & & & \\
\hline 1985 & 203 & 263 & 254 & & & & & & & & \\
\hline 1986 & 175 & 235 & 213 & & & & & & & & \\
\hline 1987 & 254 & 374 & 357 & & & & & & & & \\
\hline 1988 & 152 & 211 & 203 & & & & & & & & \\
\hline 1989 & 226 & 240 & 245 & $5.5 \times 10^{-5}$ & $9.7 \times 10^{-6}$ & $1.8 \times 10^{-8}$ & $1.7 \times 10^{-8}$ & $4.4 \times 10^{-7}$ & $1.3 \times 10-7$ & $1.6 \times 10^{-5}$ & $1.6 \times 10-5$ \\
\hline 1990 & 336 & 447 & 367 & & & & & & & & \\
\hline 1991 & 328 & 550 & 453 & & & & & & & & \\
\hline 1992 & $33 i$ & 350 & 279 & & & & & & & & \\
\hline 1993 & 419 & 566 & 416 & & & & & & & & \\
\hline 1994 & 347 & 421 & 348 & & & & & & & & \\
\hline Total & & & & $1.3 \times 10^{2}$ & $1.5 \times 10^{1}$ & $5.6 \times 10^{-3}$ & $2.3 \times 10^{-2}$ & $1.4 \times 10^{-1}$ & $1.7 \times 10^{-1}$ & $2.5 \times 10^{1}$ & $2.5 \times 10^{1}$ \\
\hline
\end{tabular}




\begin{tabular}{|c|c|c|c|c|c|c|c|c|c|c|c|}
\hline Year & $\begin{array}{c}\text { River Flow } \\
\text { Rate } \\
\left(\mathrm{m}^{3} / \mathrm{s}\right)^{\mathrm{a}}\end{array}$ & $\begin{array}{l}\text { B-J Derived } \\
\text { Flow Rate } \\
\left(\mathrm{m}^{3} / \mathrm{s}\right)\end{array}$ & $\begin{array}{c}\text { PW Derived } \\
\text { Flow Rate } \\
\left(\mathrm{m}^{3} / \mathrm{s}\right)\end{array}$ & $\begin{array}{c}\text { Releases to } \\
\text { Streams } \\
\text { (Ci) }\end{array}$ & $\begin{array}{l}\text { Max Ind } \\
\text { Below SRS } \\
\text { (mrem) }\end{array}$ & $\begin{array}{c}\text { Max } \\
\text { Ind } \\
\text { BJ } \\
\text { (mrem) }\end{array}$ & $\begin{array}{c}\text { Max } \\
\text { Ind } \\
\text { PW } \\
\text { (mrem) }\end{array}$ & $\begin{array}{l}\text { Pop Dose } \\
\text { BJ } \\
\text { (per-rem) }\end{array}$ & $\begin{array}{l}\text { Pop Dose PW } \\
\text { (per-rem) }\end{array}$ & $\begin{array}{c}\text { Pop Dose } 80 \\
\text { km } \\
\text { (per-rem) }\end{array}$ & $\begin{array}{l}\text { Pop Dose } \\
\text { Total } \\
\text { (per-rem) }\end{array}$ \\
\hline 1954 & 209 & & 263 & $4.5 \times 10^{-2}$ & $1.3 \times 10^{-4}$ & & $8.2 \times 10^{-5}$ & & $6.3 \times 10^{-4}$ & $1.8 \times 10^{-2}$ & $1.9 \times 10^{-2}$ \\
\hline 1955 & 169 & & 213 & $1.7 \times 10^{0.1}$ & $6.2 \times 10^{-4}$ & & $3.8 \times 10^{-4}$ & & $2.9 \times 10^{-3}$ & $8.5 \times 10^{-2}$ & $8.8 \times 10-2$ \\
\hline 1956 & 179 & & 225 & $4.6 \times 10^{0.1}$ & $1.6 \times 10^{-3}$ & & $9.8 \times 10^{-4}$ & & $7.5 \times 10^{-3}$ & $2.2 \times 10^{-1}$ & $2.2 \times 10^{-1}$ \\
\hline 1957 & 235 & & 297 & $2.2 \times 10^{0}$ & $5.8 \times 10.3$ & & $3.6 \times 10^{-3}$ & & $2.7 \times 10^{-2}$ & $7.9 \times 10^{-1}$ & $8.2 \times 10^{-1}$ \\
\hline 1958 & 313 & & 394 & $8.1 \times 10^{0.1}$ & $1.6 \times 10^{-3}$ & & $9.9 \times 10^{-4}$ & & $7.6 \times 10^{-3}$ & $2.2 \times 10^{-1}$ & $2.3 \times 10^{-4}$ \\
\hline 1959 & 276 & & 348 & $2.1 \times 10^{0}$ & $4.7 \times 10^{-3}$ & & $2.9 \times 10^{-3}$ & & $2.2 \times 10^{-2}$ & $6.4 \times 10^{-1}$ & $6.6 \times 10^{-1}$ \\
\hline 1960 & 371 & & 468 & $9.1 \times 10^{0}$ & $1.5 \times 10^{-2}$ & & $9.3 \times 10^{-3}$ & & $7.1 \times 10^{-2}$ & $2.1 \times 10^{0}$ & $21 \times 10^{0}$ \\
\hline 1961 & 309 & & 389 & $7.0 \times 10^{0}$ & $1.4 \times 10^{-2}$ & & $8.7 \times 10^{-3}$ & & $6.6 \times 10^{-2}$ & $1.9 \times 10^{0}$ & $20 \times 100$ \\
\hline 1962 & 300 & & 377 & $6.9 \times 10^{0}$ & $1.4 \times 10^{-2}$ & & $8.8 \times 10^{-3}$ & & $6.7 \times 10^{-2}$ & $20 \times 100$ & $2.0 \times 100$ \\
\hline 1963 & 315 & & 397 & $1.3 \times 101$ & $2.5 \times 10.2$ & & $1.5 \times 10^{-2}$ & & $1.2 \times 10^{-1}$ & $3.4 \times 100$ & $3.5 \times 100$ \\
\hline 1964 & 580 & & 731 & $7.9 \times 10^{9}$ & $8.4 \times 10^{-3}$ & & $5.2 \times 10^{0.3}$ & & $4.0 \times 10^{-2}$ & $1.2 \times 10^{0}$ & $1.2 \times 10^{0}$ \\
\hline 1965 & 362 & 800 & 456 & $3.9 \times 10^{0}$ & $6.7 \times 10^{-3}$ & $2.3 \times 10^{-3}$ & $4.1 \times 10^{-3}$ & $5.9 \times 10^{-2}$ & $3.1 \times 10^{-2}$ & $9.1 \times 10^{-1}$ & $1.0 \times 100$ \\
\hline 1966 & 316 & 520 & 399 & $1.3 \times 10^{0}$ & $2.5 \times 10^{-3}$ & $1.2 \times 10^{-3}$ & $1.5 \times 10^{-3}$ & $3.0 \times 10^{-2}$ & $1.2 \times 10^{-2}$ & $3.4 \times 10^{-1}$ & $3.8 \times 10^{-1}$ \\
\hline 1967 & 299 & 625 & 377 & $1.9 \times 10^{0}$ & $4.0 \times 10^{-3}$ & $1.5 \times 10^{-3}$ & $2.5 \times 10^{-3}$ & $3.8 \times 10^{-2}$ & $1.9 \times 10^{-2}$ & $5.5 \times 10^{-1}$ & $6.1 \times 10^{-1}$ \\
\hline 1968 & 273 & 470 & 343 & $1.9 \times 10^{0}$ & $4.3 \times 10^{-3}$ & $1.9 \times 10^{-3}$ & $2.7 \times 10^{-3}$ & $4.9 \times 10^{-2}$ & $2.0 \times 10^{-2}$ & $5.9 \times 10^{-1}$ & $6.6 \times 10^{-1}$ \\
\hline 1969 & 310 & 624 & 390 & $5.2 \times 10.1$ & $1.0 \times 10^{-3}$ & $4.0 \times 10^{-4}$ & $6.4 \times 10^{-4}$ & $1.0 \times 10^{-2}$ & $4.9 \times 10^{-3}$ & $1.4 \times 10.1$ & $1.6 \times 10^{-1}$ \\
\hline 1970 & 232 & 772 & 293 & $6.1 \times 10^{-2}$ & $1.6 \times 10^{-4}$ & $3.8 \times 10^{-5}$ & $1.0 \times 10^{-4}$ & $9.6 \times 10^{-4}$ & $7.7 \times 10^{4}$ & $2.2 \times 10-2$ & $2.4 \times 10^{-2}$ \\
\hline 1971 & 303 & 1245 & 381 & $3.4 \times 10.2$ & $7.1 \times 10.5$ & $1.3 \times 10^{-5}$ & $4.3 \times 10^{-3}$ & $3.4 \times 10^{-4}$ & $3.3 \times 10^{-4}$ & $9.7 \times 10^{-3}$ & $1.0 \times 10^{-2}$ \\
\hline 1972 & 318 & 775 & 401 & $3.9 \times 10^{-2}$ & $7.6 \times 10-5$ & $2.4 \times 10^{-5}$ & $4.7 \times 10.5$ & $6.1 \times 10^{-4}$ & $3.6 \times 10^{-4}$ & $1.0 \times 10.2$ & $1.1 \times 10^{-2}$ \\
\hline 1973 & 409 & 656 & 468 & $4.8 \times 10^{-2}$ & $7.3 \times 10^{-5}$ & $3.5 \times 10^{-5}$ & $4.9 \times 10.5$ & $8: 9 \times 10^{-4}$ & $3.8 \times 10^{-4}$ & $1.0 \times 10^{-2}$ & $1.1 \times 10^{-2}$ \\
\hline 1974 & 314 & 640 & 373 & $4.0 \times 10^{-3}$ & $7.9 \times 10^{-6}$ & $3.0 \times 10^{-6}$ & $5.2 \times 10^{-6}$ & $7.6 \times 10.5$ & $3.9 \times 10^{-5}$ & $1.1 \times 10^{-3}$ & $1.2 \times 10^{-3}$ \\
\hline 1975 & 436 & 877 & 538 & $5.4 \times 10^{-2}$ & $7.7 \times 10^{-5}$ & $3.0 \times 10^{-5}$ & $4.8 \times 10^{-5}$ & $7.5 \times 10^{-4}$ & $3.7 \times 10^{-4}$ & $1.1 \times 10.2$ & $1.2 \times 10^{-2}$ \\
\hline 1976 & 394 & 996 & 472 & $1.0 \times 10^{-3}$ & $1.6 \times 10^{-6}$ & $4.8 \times 10.7$ & $1.0 \times 10^{-6}$ & $1.2 \times 10^{-5}$ & $7.8 \times 10^{-6}$ & $2.2 \times 10^{-4}$ & $2.4 \times 10^{-4}$ \\
\hline 1977 & 330 & 562 & 433 & $1.0 \times 10^{-3}$ & $1.9 \times 10^{-6}$ & $8.8 \times 10^{-7}$ & $1.1 \times 10.6$ & $2.2 \times 10^{-5}$ & $8.7 \times 10^{-6}$ & $2.7 \times 10^{-4}$ & $3.0 \times 10^{-4}$ \\
\hline 1978 & 298 & 689 & 324 & & & & & & & & \\
\hline 1979 & 375 & 989 & 495 & & & & & & & & \\
\hline 1980 & 374 & 863 & 488 & & & & & & & & \\
\hline 1981 & 187 & 331 & 243 & & & & & & & & \\
\hline 1982 & 203 & 555 & 287 & & & & & & & & \\
\hline 1983 & 350 & 361 & 417 & & & & & & & & \\
\hline 1984 & 361 & 747 & 487 & & & & & & & & \\
\hline 1985 & 203 & 263 & 254 & & & & & & & & \\
\hline 1986 & 175 & 235 & 213 & & & & & & & & \\
\hline 1987 & 254 & 374 & 357 & & & & & & & & \\
\hline 1988 & 152 & 211 & 203 & & & & & & & & \\
\hline 1989 & 226 & 240 & 245 & $4.7 \times 10^{-3}$ & $1.3 \times 10^{-5}$ & $9.4 \times 10^{-6}$ & $9.2 \times 10.6$ & $2.4 \times 10^{-4}$ & $7.1 \times 10^{-5}$ & $1.8 \times 10^{-3}$ & $2.1 \times 10^{-3}$ \\
\hline 1990 & 336 & 447 & 367 & & & & & & & & \\
\hline 1991 & 328 & 550 & 453 & & & & & & & & \\
\hline 1992 & 331 & 350 & 279 & & & & & & & & \\
\hline 1993 & 419 & 566 & 416 & & & & & & & & \\
\hline 1994 & 347 & 421 & 348 & & & & & & & & \\
\hline TOTAL & & & & $5.9 \times 101$ & $1.1 \times 10.1$ & $7.5 \times 10^{-3}$ & $6.8 \times 10.2$ & $1.9 \times 10^{-1}$ & $5.2 \times 10^{-1}$ & $1.5 \times 10^{1}$ & $1.6 \times 10^{1}$ \\
\hline
\end{tabular}




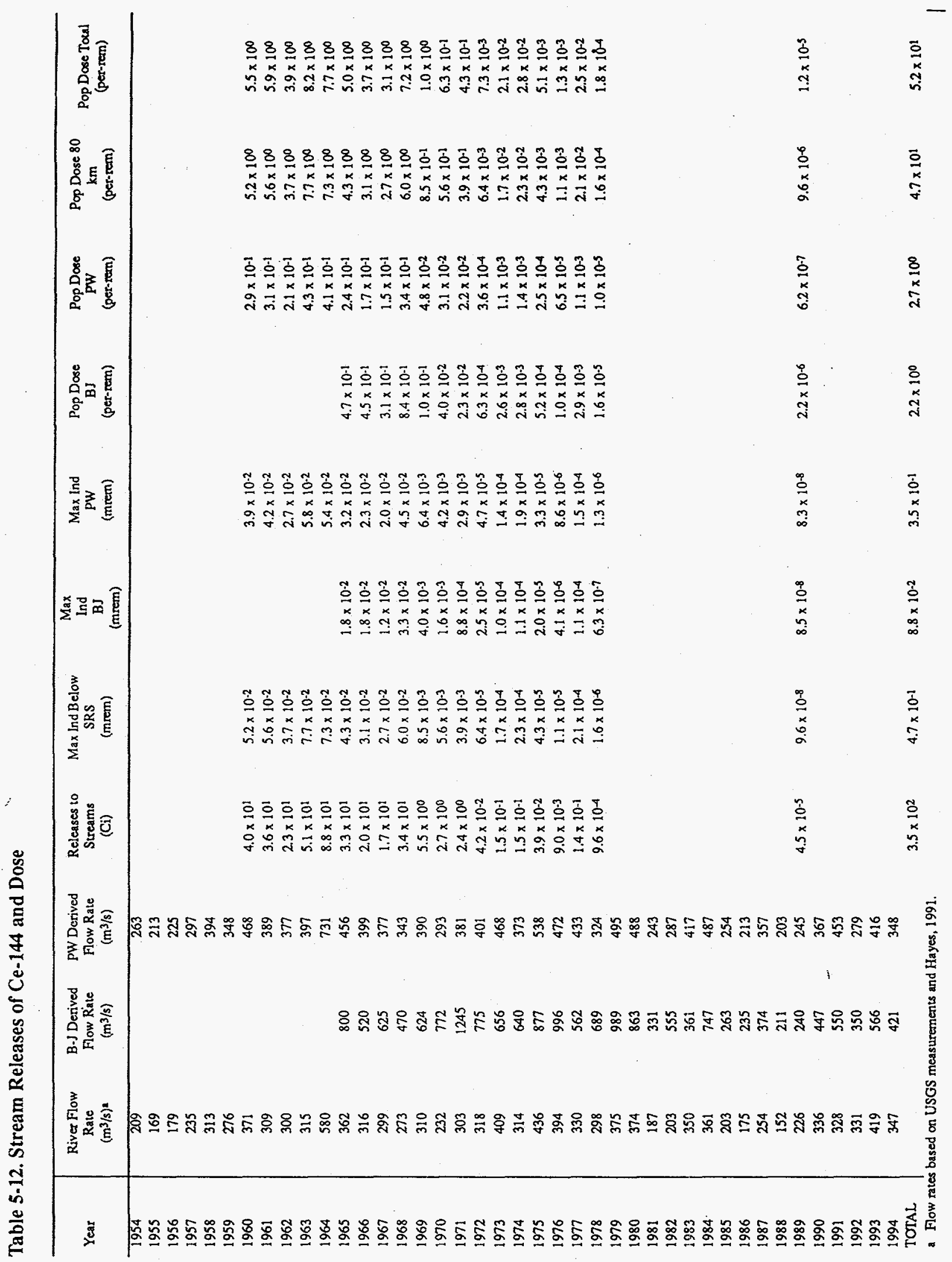




\section{Additional Reading}

The following documents in the Radiological Assessment Program series are available to the public from National Technical Information Service

U.S. Department of Commerce 5285 Port Royal Road Springfield, VA 22161

Assessment of Activation Products in the Savannah River Site Environment WSRC-TR-95-0422

Assessment of Radiocarbon in the Savannah River Site Environment WSRC-TR-93-215

Cesium in the Savannah River Site Environment WSRC-RP-92-250

Radioiodine in the Savannah River Site Environment WSRC-RP-90-424-2
Assessment of Mercury

in the Savannah River Site Environment WSRC-TR-94-0218-ET

Assessment of Noble Gases

in the Savannah River Site Environment WSRC-TR-95-219

Assessment of Plutonium in the Savannah River Site Environment WSRC-RP-92-879, Rev 1

Assessment of Strontium in the Savannah River Site Environment WSRC-RP-92-984

Assessment of Technetium in the Savannah River Site Environment WSRC-TR-93-217

Assessment of Tritium in the Savannah River Site Environment WSRC-TR-93-214

Uraniuna in the Savannah River Site Environment WSRC-RP-92-315 


\section{SAVANNAH RIVER SITE}

\section{U.S. Department of Energy/Savannah River Field Office}

D. Hannah (60)

$703-46 \mathrm{~A}$

\section{Westinghouse Savannah River Company}

R.P. Addis

L. Bagwell

D.M. Beals

R.W. Benjamin

D.T. Bignell

A.L. Boni

P.D. Campbell

T.L. Capeletti

W.H. Carlton (80)

G. Clare

J.R. Cook

J.W. Cook

J.C. Corey

K.W. Crase

F.B. Davis

M. Denham

M. Dodgen

M.A. Ebra

W.A. Emel

J.B. Gladden

D.E. Gordon

J.E. Halverson

D.W. Hayes

L.A. Haselow

J.D. Heffner

M.J. Hitchler
773-A

724-21E

735-A

703-45A

742-A

773-A

705-A

773-41A

773-A

704-C

773-43A

742-A

$773-41 \mathrm{~A}$

735-A

703-A

773-42A

735-11A

773-41A

735-A

$773-42 \mathrm{~A}$

742-A

735-A

735-A

730-2B

735-16A

730-2B
H.P. Holcomb

E.W. Holtzscheiter

G.T. Jannik

G.F. Jernigan

N.D. Johnson

M.V. Kantelo

K. Kuelske

R. Lorenz

W.S. Loring

D.K. Martin

L.C. Martin

D.B. Moore-Shedrow

C.E. Murphy, Jr.

R.L. Nichols

J.V. Odum

L.M. Papouchado

J.B. Pickett

A.A. Simpkins

H.J. Stafford

D.E. Stephenson

W.E. Stevens

R.N. Strom

D.M. Tuck

E.L. Wilhite

W.G. Winn

S. Wood
730-2B

773-A

773-A

$730-2 B$

$730-4 \mathrm{~B}$

735-A

730-2B

735-16A

$730-4 \mathrm{~B}$

730-2B

742-A

773-A

773-42A

773-42A

742-A

773-A

$730-\mathrm{M}$

773-A

$730-4 \mathrm{~B}$

730-2B

773-A

$773-42 \mathrm{~A}$

$773-42 \mathrm{~A}$

$773-43 A$

735-A

773-A

\section{Savannah River Ecology Laboratory}

$\begin{array}{ll}\text { P. Bertsch } & \text { 737-A } \\ \text { S.B. Clark } & 737-A \\ \text { T. Hinton } & 737-A \\ \text { M.C. Newman } & 737-A\end{array}$

J.E. Pinder

M.H. Smith

C.L. Strojan

F.W. Whicker
737-A

737-A

737-A

737-A

\section{EXTERNAL}

Environmental Advisory Committee c/o C.E. Murphy, Jr., 773-42A (6)

J.E. Till, Neeses, SC 